Western University

Scholarship@Western

Surgery Publications

Surgery Department

2010

Hypertonic Saline for Peri-operative Fluid Management

Vivian McAlister

University of Western Ontario, vmcalist@uwo.ca

Karen E.A. Burns

University of Toronto

Tammy Znajda

Lakeshore General Hospital, Pointe-Claire, QC

Brian Church

University of Western Ontario, bchurch2@uwo.ca

Follow this and additional works at: https://ir.lib.uwo.ca/surgerypub

Part of the Anesthesiology Commons, and the Surgery Commons

Citation of this paper:

McAlister, Vivian; Burns, Karen E. A.; Znajda, Tammy; and Church, Brian, "Hypertonic Saline for Peri-operative Fluid Management" (2010). Surgery Publications. 27.

https://ir.lib.uwo.ca/surgerypub/27 


\title{
Hypertonic saline for peri-operative fluid management (Review)
}

\author{
McAlister V, Burns KEA, Znajda T, Church B
}

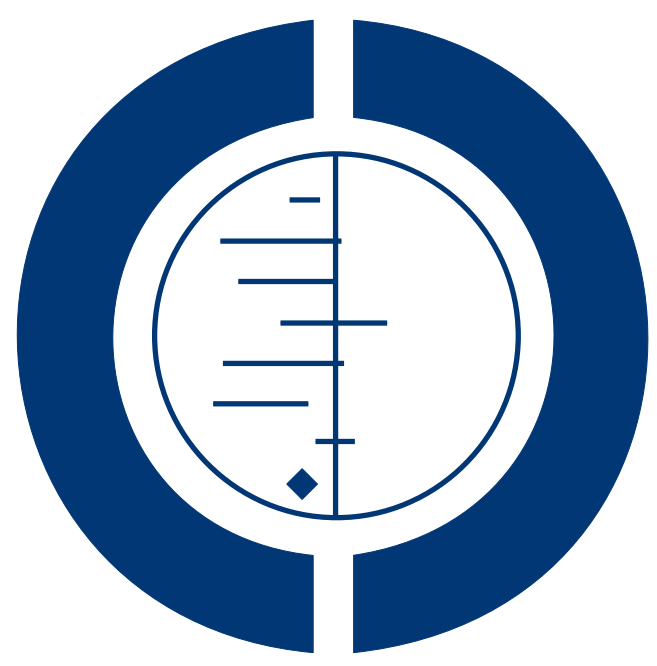

\section{THE COCHRANE COLLABORATION $^{\circledR}$}

This is a reprint of a Cochrane review, prepared and maintained by The Cochrane Collaboration and published in The Cochrane Library 2010, Issue 1

http://www.thecochranelibrary.com

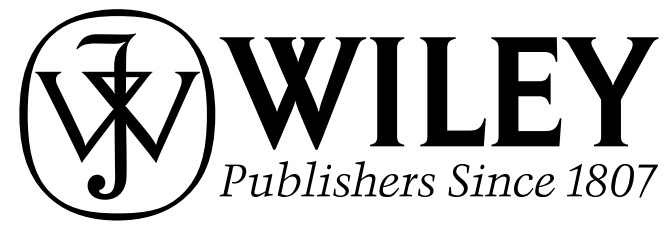

Hypertonic saline for peri-operative fluid management (Review)

Copyright (C) 2010 The Cochrane Collaboration. Published by John Wiley \& Sons, Ltd. 
TABLE OF CONTENTS

HEADER . . . . . . . . . . . . . . . . . . . . . . . . . . . . . . . . . . . . . . . 1

ABSTRACT . . . . . . . . . . . . . . . . . . . . . . . . . . . . . . . . . . . . . . 1

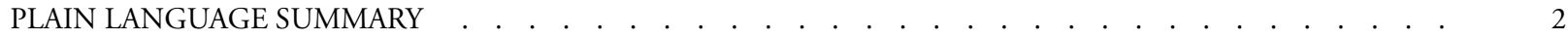

BACKGROUND . . . . . . . . . . . . . . . . . . . . . . . . . . . . . . . . . . 2

OBJECTIVES . . . . . . . . . . . . . . . . . . . . . . . . . . . . . . . . . . 3

METHODS . . . . . . . . . . . . . . . . . . . . . . . . . . . . . . . . . . . . . . 3

RESULTS . . . . . . . . . . . . . . . . . . . . . . . . . . . . . . . . . . . . . . . 5

Figure 1. . . . . . . . . . . . . . . . . . . . . . . . . . . . . . . . . . . . . 6

Figure 2. . . . . . . . . . . . . . . . . . . . . . . . . . . . . . . . . . . . 8

Figure 3. . . . . . . . . . . . . . . . . . . . . . . . . . . . . . . . . . . . . . . . 9

Figure $4 . \quad$. . . . . . . . . . . . . . . . . . . . . . . . . . . . . . . . . . . . . 10

DISCUSSION . . . . . . . . . . . . . . . . . . . . . . . . . . . . . . . 10

AUTHORS' CONCLUSIONS . . . . . . . . . . . . . . . . . . . . . . . . . . . . . . . . . . . . . . . . 11

ACKNOWLEDGEMENTS . . . . . . . . . . . . . . . . . . . . . . . . . . . . . . . . . . . . . . . . . 11

REFERENCES . . . . . . . . . . . . . . . . . . . . . . . . . . . . . . . . . . . . . 12

CHARACTERISTICS OF STUDIES . . . . . . . . . . . . . . . . . . . . . . . . . . . . . 14

DATA AND ANALYSES . . . . . . . . . . . . . . . . . . . . . . . . . . . . . . . . . . . . . . . . . . . . 32

Analysis 3.1. Comparison 3 Fluid balance (L), Outcome 1 Calculated fluid balance (stratified for surgery type). . . $\quad 35$

Analysis 3.2. Comparison 3 Fluid balance (L), Outcome 2 Calculated fluid balance (stratified for dose of HS given). 36

Analysis 3.3. Comparison 3 Fluid balance (L), Outcome 3 Calculated fluid balance (stratified for volume given in control group). . . . . . . . . . . . . . . . . . . . . . . . . . . . . . . . . . . . 37

Analysis 3.4. Comparison 3 Fluid balance (L), Outcome 4 Calculated fluid balance (sensitivity analysis by study quality). 38

Analysis 3.5. Comparison 3 Fluid balance (L), Outcome 5 Actual fluid balance (L). . . . . . . . . . . . . . . . . 39

Analysis 4.1. Comparison 4 Total volume of crystalloid administered (L), Outcome 1 Volume of crystalloid administered (stratified for type of surgery).

Analysis 4.2. Comparison 4 Total volume of crystalloid administered (L), Outcome 2 Volume of crystalloid administered (stratified by dose of HS).

Analysis 4.3. Comparison 4 Total volume of crystalloid administered (L), Outcome 3 Volume of crystalloid administered (sensitivity analysis by study quality).

Analysis 5.1. Comparison 5 Diuresis during study period (L), Outcome 1 Diuresis during study period (L). . . . . 43

Analysis 5.2. Comparison 5 Diuresis during study period (L), Outcome 2 Diuresis during study period (stratified by dose of HS)

Analysis 5.3. Comparison 5 Diuresis during study period (L), Outcome 3 Diuresis during study period (stratified for type of surgery).

Analysis 5.4. Comparison 5 Diuresis during study period (L), Outcome 4 Diuresis during study period (stratified for volume of crystalloid infused)

Analysis 5.5. Comparison 5 Diuresis during study period (L), Outcome 5 Diuresis during study period (sensitivity analysis by study quality).

Analysis 6.1. Comparison 6 Peak serum sodium (meq/L), Outcome 1 Peak serum sodium (stratified by type of surgery).

Analysis 6.2. Comparison 6 Peak serum sodium (meq/L), Outcome 2 Peak serum sodium (stratified by dose of HS).

Analysis 6.3. Comparison 6 Peak serum sodium (meq/L), Outcome 3 Peak serum sodium (stratified by volume given in control group).

Analysis 6.4. Comparison 6 Peak serum sodium (meq/L), Outcome 4 Peak serum sodium (sensitivity analysis by study quality). . . . . . . . . . . . . . . . . . . . . . . . . . . . . . . . . 51

Analysis 7.1. Comparison 7 Final serum sodium (meq/L), Outcome 1 Final serum sodium (all studies). . . . . . $\quad . \quad 52$

Analysis 7.2. Comparison 7 Final serum sodium (meq/L), Outcome 2 Final serum sodium (stratified by dose of HS given).

Analysis 7.3. Comparison 7 Final serum sodium (meq/L), Outcome 3 Final serum sodium (stratified by volume given in control group).

Analysis 7.4. Comparison 7 Final serum sodium (meq/L), Outcome 4 Final serum sodium (stratified by type of surgery). 
Analysis 7.5. Comparison 7 Final serum sodium (meq/L), Outcome 5 Final serum sodium (sensitivity analysis by study quality). . . . . . . . . . . . . . . . . . . . . . . . . . . . . . . . . . . . .

Analysis 12.1. Comparison 12 Other outcomes of interest, Outcome 1 Maximum intraoperative serum osmolarity $(\mathrm{mOsm} / \mathrm{kg} \mathrm{H} 2 \mathrm{O}) . \quad$. . . . . . . . . . . . . . . . . . . . . . . . . . . . . . . . . . . . . . . . . .

Analysis 12.2. Comparison 12 Other outcomes of interest, Outcome 2 Maximum intraoperative pulmonary artery wedge pressure $(\mathrm{mm} \mathrm{Hg}) . \quad$. . . . . . . . . . . . . . . . . . . . . . . . . . . . . . . . . . . . .

Analysis 12.3. Comparison 12 Other outcomes of interest, Outcome 3 Maximum intraoperative cardiac index

$(\mathrm{L} / \mathrm{min} / \mathrm{M} 2)$. . . . . . . . . . . . . . . . . . . . . . . . . . . . . 58

APPENDICES . . . . . . . . . . . . . . . . . . . . . . . . . . . . . . . . . . . . . . 58

HISTORY . . . . . . . . . . . . . . . . . . . . . . . . . . . . . . . . . . . . . . . 63

CONTRIBUTIONS OF AUTHORS . . . . . . . . . . . . . . . . . . . . . . . . . . . . . . . 63

DECLARATIONS OF INTEREST . . . . . . . . . . . . . . . . . . . . . . . . . . . . . . 64 


\title{
[Intervention Review]
}

\section{Hypertonic saline for peri-operative fluid management}

\author{
Vivian McAlister ${ }^{1}$, Karen EA Burns ${ }^{2}$, Tammy Znajda ${ }^{3}$, Brian Church $^{4}$ \\ ${ }^{1}$ Canadian Forces Medical Service, University of Western Ontario, London, Canada. ${ }^{2}$ Interdepartmental Division of Critical Care and \\ the University of Toronto, Keenan Research Centre/Li Ka Shing Knowledge Institute, Toronto, Canada. ${ }^{3}$ Departments of General \\ Surgery and Intensive Care Medicine, Lakeshore General Hospital, Pointe-Claire, Canada. ${ }^{4} 1$ Canadian Field Hospital, Canadian \\ Forces Medical Service, Department of Anesthesia, University of Western Ontario, London, Canada
}

Contact address: Vivian McAlister, Canadian Forces Medical Service, University of Western Ontario, C4-212, University Hospital, London, Ontario, N6A 5A5, Canada.vmcalist@uwo.ca.

Editorial group: Cochrane Anaesthesia Group.

Publication status and date: New, published in Issue 1, 2010.

Review content assessed as up-to-date: 31 July 2009.

Citation: McAlister V, Burns KEA, Znajda T, Church B. Hypertonic saline for peri-operative fluid management. Cochrane Database of Systematic Reviews 2010, Issue 1. Art. No.: CD005576. DOI: 10.1002/14651858.CD005576.pub2.

Copyright (C) 2010 The Cochrane Collaboration. Published by John Wiley \& Sons, Ltd.

\begin{abstract}
A B S T R A C T

\section{Background}

Fluid excess may place patients undergoing surgery at risk for various complications. Hypertonic saline (HS) maintains intravascular volume with less intravenous fluid than isotonic salt (IS) solutions, but may increase serum sodium.
\end{abstract}

\section{Objectives}

To determine the benefits and harms of HS versus IS solutions administered to patients undergoing surgery.

\section{Search strategy}

We searched the Cochrane Central Register of Controlled Trials (CENTRAL), (The Cochrane Library) Issue 1, 2009; MEDLINE (1966 to 2009); EMBASE (1980 to 2009); LILACS (to August 2009) and CINAHL (1982 to 2009) without language restrictions.

\section{Selection criteria}

We included randomized clinical trials where HS was compared to IS in patients undergoing surgery, irrespective of blinding, language, and publication status.

\section{Data collection and analysis}

We assessed the impact of HS administration on mortality, organ failure, fluid balance, serum sodium, serum osmolarity, diuresis and physiologic measures of cardiovascular function. We pooled data using odds ratio or mean difference (MD) for binary and continuous outcomes, respectively, using random-effects models.

\section{Main results}

We included 15 studies with 614 participants. One death in each group and no other serious adverse events were reported. While all patients were in a positive fluid balance postoperatively, the excess was significantly less in HS patients (standardized mean difference (SMD) -1.43L, 95\% confidence interval (CI) 0.8 to $2.1 \mathrm{~L}$ less; $\mathrm{P}<0.00001$ ). Patients treated with HS received significantly less fluid than IS-treated patients (MD -2.4L 95\% (CI) 1.5 to $3.2 \mathrm{~L}$ less; $\mathrm{P}<0.00001$ ) without differences in diuresis between the groups. Maximum intraoperative cardiac index was significantly increased with HS (SMD 0.6 L/min/M2 higher, $95 \%$ CI 0.1 to $1.0, \mathrm{P}=0.02$ ) but Intraoperative pulmonary artery wedge pressure remained unchanged. While the maximum serum sodium and the serum sodium at the end of the study were significantly higher in HS patients, the level remained within normal limits (136 to $146 \mathrm{meq} / \mathrm{L}$ ). 


\section{Authors' conclusions}

HS reduces the volume of intravenous fluid required to maintain patients undergoing surgery but transiently increases serum sodium. It is not known if HS effects patient survival and morbidity but it should be tested in randomized clinical trials that are designed and powered to test these outcomes.

\section{PLAIN LANGUAGE SUMMARY}

\section{Hypertonic saline for peri-operative fluid management}

Patients usually require intravenous fluids during surgery. Sometimes large volumes of fluid are given during operations in order to maintain adequate blood pressure, but these volumes may leave patients with an excessive fluid load in the post-operative period. Hypertonic saline has a higher sodium concentration than isotonic solutions which have concentrations similar to the blood stream. Hypertonic saline might benefit patients undergoing surgery by reducing the total volume of fluid required. This review includes 15 trials comparing hypertonic saline to isotonic saline in patients undergoing surgery. These trials suggests that less fluid is required for maintenance of arterial blood pressure and blood volume in these patients during surgery if hypertonic saline is given. Kidney function was good in both groups but the serum sodium was higher in patients given hypertonic saline. The trials were too small to see important differences in patient survival or organ failure.

\section{B A C K G R O U N D}

Low volume resuscitation with hypertonic crystalloid solutions has been investigated for over 20 years (Shackford 1983). More recently, alterations in cellular immune function with hypertonic saline (HS) administration have been demonstrated in experimental and clinical studies (Kolsen-Petersen 2004; Rizoli 2006). Several randomized clinical trials (RCTs) of HS resuscitation in critically ill patients have been performed. A systematic review of HS compared to isotonic solution in resuscitation following burns or trauma was unable to reach a conclusion regarding benefit or harm in the presence of wide confidence intervals (Bunn 2004). Trials of HS alone, or in combination with colloids, have also been performed in the trauma population. A meta-analysis comparing $250 \mathrm{ml}$ of HS (with or without dextran) with administration of $250 \mathrm{ml}$ of isotonic crystalloid for the treatment of hypotension either in the field or at admission to the emergency department in 1233 trauma patients failed to demonstrate that HS with dextran confers a survival benefit (Wade 1997).

Standard perioperative care includes isotonic salt (IS) solution administration to counter conditions which may cause transient intra-operative hypovolaemia including: fluid deprivation during preoperative fasting; vasodilatation due to epidural or general anaesthesia; third space sequestration of intravascular fluid; insensible fluid loss and intraoperative fluid or blood loss. These conditions are often reversed at the end of an operation. In fact, IS solu- tion has been shown to increase the weight of patients undergoing elective major surgery by an average of three to six kilograms $(\mathrm{kg})$ (Grocott 2005). While most patients tolerate the additional fluid well, postoperative improvement or reversal of the conditions outlined above may place patients with compromised cardiovascular or renal function at increased risk for development of pulmonary oedema. Patients without cardiovascular or renal risk factors may also be adversely affected by perioperative fluid gain. A recent RCT demonstrated that perioperative fluid restriction resulted in fewer major or minor postoperative complications compared to traditional care in 172 adult patients undergoing elective colorectal surgery (Brandstrup 2003). Another study demonstrated that fluid overload delayed return of gastrointestinal function (Lobo 2002). Conversely, failure to maintain intravascular volume during surgery may place patients at risk for cardiac or cerebral ischaemia. Indeed supplemental perioperative fluid administration has been shown to improve tissue oxygenation (Arkilic 2003).

HS has the potential to reduce the total volume of fluid administered during operative procedures by allowing patients to draw fluid from the interstitium (and other body compartments) to counter perioperative hypotensive effects and thereby provide Intravascular support without excess fluid administration. In situations where large volume resuscitation may be harmful, such as in brain trauma, a role for HS is emerging (Ogden 2005). Notwith- 
standing, several risks have been associated with HS including the potential hypernatraemia, metabolic acidosis and vasodilatation. Several RCTs of prophylactic HS administration in the perioperative period have been published. In contrast to other trials where HS has been combined with colloid solutions to treat hypotension, these RCTs may provide a clinical picture of the effect of HS on perioperative fluid management.

\section{O B J E C T IVES}

To determine the benefits and harms of HS versus IS solutions administered to patients undergoing surgery.

\section{METHODS}

\section{Criteria for considering studies for this review}

\section{Types of studies}

We included RCTs comparing the administration of HS versus IS solution during operative procedures, regardless of language or publication status.

\section{Types of participants}

We included patients undergoing any surgical procedures.

\section{Types of interventions}

We included perioperative administration of either HS or IS solutions. We permitted concomitant measures so long as they applied to both arms of the study. We excluded studies that compared HS and a colloidal solution to IS alone. Additionally, we excluded studies that compared HS and IS solutions administered by inhalation or absorption from the nasal mucosa and involving nonsurgical patient populations (burns, trauma and head injury).

\section{Types of outcome measures}

\section{Primary outcomes}

1. Mortality

2. Organ failure. Organ failure was recorded if it was so defined by each trial or if any of the following occurred: any requirement for dialysis (renal failure) or prolonged ventilation (pulmonary failure); use of medical therapy for either pulmonary oedema or circulatory support (cardiac failure) or for confusion (cerebral failure).

\section{Secondary outcomes}

3. Fluid balance over the study period. We used authors definitions where provided. For studies not clearly specifying the study period, we defined it to include the immediate preoperative (induction of anaesthesia), intraoperative and postoperative periods (up to 24 hours after surgery). For studies that only reported weight change, we applied a conversion factor, wherein $1 \mathrm{~kg}=1 \mathrm{~L}$, to calculate fluid balance.

4. Total volume of intravenous fluid

5. Perioperative diuresis

6. Maximum serum sodium concentration in the perioperative period

7. Final serum sodium

8. Duration of endotracheal intubation after operation

9. Duration of stay in intensive care after operation

10. Duration of stay in hospital after operation

11 . We recorded any reported serious adverse events such as myocardial infarction, cerebrovascular accidents or central pontine myelinolysis.

\section{Other outcomes}

12. We collected data regarding actual fluid balance, serum osmolarity and perioperative haemodynamic parameters if they were reported by individual trials.

\section{Search methods for identification of studies}

\section{Electronic searches}

We searched the current issue of the Cochrane Central Register of Controlled Trials (CENTRAL), (The Cochrane Library Issue 1, 2009); MEDLINE (1966 to August 2009); EMBASE (1980 to 2009 week 18); CINAHL (1982 to August 2009 week 1) and LILACS (to August 2009) for RCTs comparing hypertonic and balanced salt solution administration in the perioperative period. We originally used the search strategy described in the appendices (Appendix 1 MEDLINE; Appendix 2 EMBASE; Appendix 3 CINAHL; Appendix 4 LILACS; Appendix 5 CENTRAL) to search until April 2007. We updated this search to August 2009 (see Appendix 6).

We limited the publication types to clinical trials, controlled clinical trials, RCTs, multi-centre studies and meta-analyses.

In addition we searched trial registries including http:// clinicaltrials.gov/, http://www.controlled-trials.com/ and http:// www.ifpma.org/clinicaltrials.html for ongoing trials. We sought letter or email contact with principal investigators to inform them of the meta-analysis and to ask for additional information.

We did not apply any language restrictions. 


\section{Searching other resources}

We hand searched the bibliographies of retrieved articles and the abstracts of conference proceedings published in Anaesthesia and Intensive Care; Anaesthesia and Analgesia; British Journal of Surgery; Critical Care Medicine; Journal of Vascular Surgery and Trauma; Injury; and Infection and Critical Care for the years 2000 to 2006.

\section{Data collection and analysis}

\section{Trial identification}

Vivian McAlister (VM) scanned titles and abstracts identified by the initial search to exclude overlapped and irrelevant studies. Two authors (Tammy Znajda (TZ) and Karen Burns (KB)) identified trials that met our inclusion criteria. Brian Church (BC) resolved differences in data recorded and all differences of opinion were otherwise resolved through discussion.

\section{Data abstraction}

Data were abstracted independently by at least two of the authors from the studies using standardized forms developed for this review. We wrote to primary study authors for information regarding missing data or data that was not clearly stated. We resolved differences of opinion through discussion. We abstracted data pertaining to the included participants, interventions applied and outcomes reported for each trial using a standardized form.

We abstracted the following details from each of the included studies:

1. patients (inclusion and exclusion criteria; mean age; proportion of men; aetiology of disease; weight before and after surgery; serum electrolytes before, during and after surgery);

2. interventions (type of surgery; concentration and volume of hypertonic saline given; total volume of fluid administered and concomitant therapy);

3. trials (setting; methodological quality; publication status; duration of follow-up and all outcomes).

If standard error of the mean was recorded in a study, we converted it to standard deviation.

\section{Methodological quality}

We followed the guidelines of the Cochrane Handbook for Systematic Reviews of Interventions (Higgins 2008). We used Review Manager Version 5.0(RevMan 5.0). We assessed factors related to applicability of findings, validity of individual studies, and certain design characteristics that affect interpretation of results, including double-blinding and adherence to the intention-to-treat principle. We evaluated the included studies for selection, performance, attrition and detection bias. All three authors independently assessed the methodological quality of the included studies including the generation of allocation sequence (evaluated adequate (if the allocation sequence was generated by a computer or random number table), unclear (if the trial was described as randomized, but the method used for the allocation sequence generation was not described) or inadequate (if a system involving dates, names, or admittance numbers were used)), allocation concealment (evaluated as A (adequate), B (unclear), C (inadequate) or D (not used)) and adherence to the intention-to-treat principle. We resolved differences of opinion through discussion until consensus was achieved.

\section{Analysis}

We assessed statistical heterogeneity using the $\mathrm{I}^{2}$ statistic (Higgins 2002). We used a random-effects model anticipating between study, as well as within study, heterogeneity (DerSimonian 1986). We performed subgroup analyses where appropriate. We summarized dichotomous and continuous outcomes using the odds ratio (OR) and mean difference (using the inverse variance method), respectively. We calculated an overall standardized mean difference (SMD).

We performed subgroup analysis, where appropriate, by calculation of an OR or SMD in each subgroup and examination of the 95\% confidence intervals (CI). A lack of overlap between two CI in the subgroup analyses was interpreted to represent a statistically significant difference. We conducted all analyses using the intention-to-treat principle where possible. If analysis based on this principle was not possible, we stated this clearly.

\section{Sensitivity analyses}

We performed sensitivity analyses for missing data and study quality.

Missing data: We employed sensitivity analyses using different approaches for imputing missing data. For the best-case scenario we assumed that none of the originally enrolled patients missing from the primary analysis in the treatment group developed the negative outcome of interest, whilst all those missing from the control group did. For the worst-case scenario we assumed the converse.

Study quality: We performed analysis based on the presence or absence of a reliable random allocation method, concealment of allocation and blinding of participants or outcome assessors.

\section{Subgroup analysis}

When appropriate after consideration of statistical and clinical heterogeneity, we performed subgroup analyses based on:

1. operation type

2. dose of HS (trials were stratified into three comparisons according to the dose of HS which was calculated as the volume of $3 \% \mathrm{HS}$ required to give the same amount of sodium: $7 \mathrm{ml} / \mathrm{kg}$ or less (comparison 01); $7.1-10 \mathrm{ml} / \mathrm{kg}$ (comparison 02); > 10 
$\mathrm{ml} / \mathrm{kg}$ (comparison 03). These dose stratifications were chosen before the review was conducted on the basis of an anticipated range of HS doses)

3. volume of crystalloid given to the control group (trials were stratified into three comparisons according to the total volume of fluid transfusion received by IS patients: $<2 \mathrm{~L}$ (comparison 01); 2 $\mathrm{L}$ to $5 \mathrm{~L}$ (comparison 02); > $5 \mathrm{~L}$ (comparison 03). These volume stratifications were chosen in advance of the review on the basis of an anticipated range of peri-operative fluid administration)

\section{RES U L T S}

\section{Description of studies}

See: Characteristics of included studies; Characteristics of excluded studies.

From 215 potential reports identified by the initial search strategy, 18 reports met the criteria for further assessment (Figure 1). Of these 18 references, we excluded three studies after detailed review because they were not randomized (Auler 1987; Shao 2005) or did not report any of the outcomes of interest (Auler 1992) (see Characteristics of excluded studies). No ongoing or recently completed studies were identified in registries of clinical trials including http://clinicaltrials.gov/; http://www.controlled-trials.com/; and http://www.ifpma.org/clinicaltrials.html. 
Figure I. Searching results

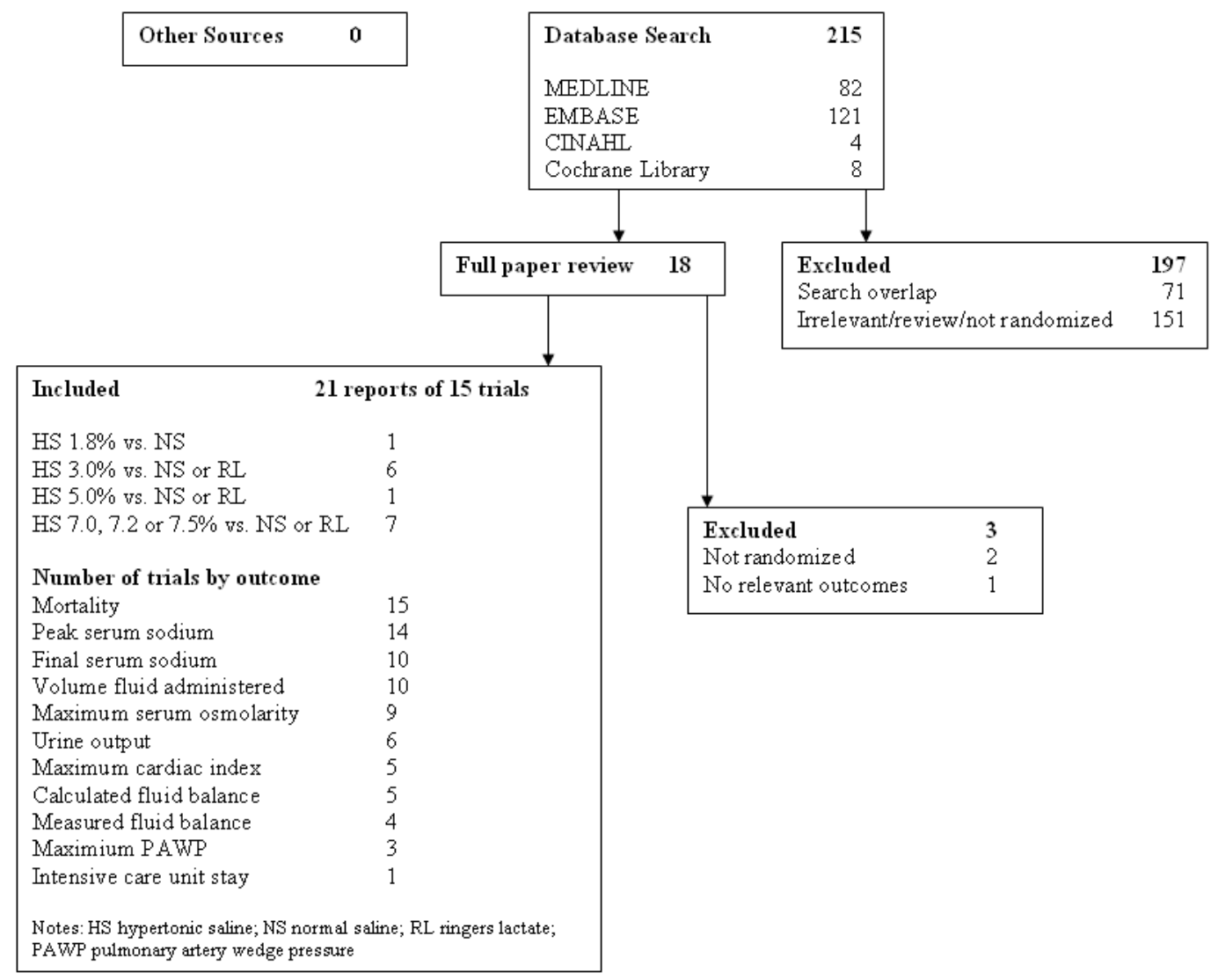

Fifteen studies including 614 participants met our inclusion criteria (Baraka 1994; Bruegger 2005; Cross 1989; Durasnel 1999; Ishikawa 1996; Jarvela 2000; Jarvela 2001; Kato 1996; Kimura 1994; Kolsen-Petersen 2004; Shackford 1983; Shackford 1987; Veroli 1992; Wang 1997; Younes 1988) (see Characteristics of included studies). The included trials were performed in a wide variety of surgical situations: aortic surgery (four trials) (Bruegger 2005; Shackford 1983; Shackford 1987; Younes 1988); lower limb surgery (three trials) (Ishikawa 1996; Jarvela 2000; Veroli 1992); transurethral prostate resection (three trials) (Baraka 1994; Kato 1996; Kimura 1994); coronary artery bypass grafting (two trials) (Cross 1989; Jarvela 2001); hysterectomy (one trial) (KolsenPetersen 2004); hernia repair (one trial) (Wang 1997); general surgery (one trial) (Durasnel 1999). Anaesthetic techniques included: general anaesthesia (eight trials) (Bruegger 2005; Cross 1989; Jarvela 2001; Kato 1996; Kolsen-Petersen 2004; Shackford 1983; Shackford 1987; Younes 1988) and spinal anaesthesia (seven trials) (Baraka 1994; Durasnel 1999; Ishikawa 1996; Jarvela 2000;
Kimura 1994; Veroli 1992; Wang 1997).

Studies were performed in nine countries. Four publications were written in languages other than English including Japanese (two trials) (Ishikawa 1996; Kimura 1994); French (one trial) (Durasnel 1999); Portuguese (one trial) (Younes 1988). The included studies had small sample sizes, enrolling between 20 and 72 patients. The interval between the first and last study was approximately 22 years (1983 to 2005). None of the studies were designed to determine differences in mortality but instead focused on fluid and haemodynamic measurement during the perioperative period. Follow-up extended into the postoperative period in eight trials (Bruegger 2005; Cross 1989; Jarvela 2000; Jarvela 2001; Kato 1996; Kolsen-Petersen 2004; Shackford 1983; Shackford 1987) for durations ranging from the stay in the recovery unit to the hospital stay while the other trials confined their observations to the period of anaesthesia. Two studies reported results with standard error which were converted to standard deviation by multiplica- 
tion with the square root of the number in the group (Shackford 1983; Shackford 1987).

\section{Risk of bias in included studies}

\section{Randomization}

Randomization procedures were described in all but four trials ( Ishikawa 1996; Kimura 1994; Wang 1997; Younes 1988). Adequate allocation concealment was reported in one trial (KolsenPetersen 2004). We verified the adequacy of allocation concealment in two further trials (Jarvela 2000; Jarvela 2001) through correspondence with the principal investigator. We could not reliably assess allocation concealment from the published reports of the remaining studies.

\section{Participant baseline characteristics}

Baseline parameters were reported in each study and appeared to be similar in both study groups in all trials.

\section{Blinding}

All studies blinded therapy to participants and investigators.

\section{Compliance with protocol}

Of the 614 enrolled participants, 607 completed the protocol. Three participants in the HS group failed to complete the study, one because of consent withdrawal (Kolsen-Petersen 2004); one for an anaphylactic reaction to another medication (KolsenPetersen 2004); and one without a reason specified (Durasnel 1999). Three participants in the IS group failed to complete the protocol, one because of an urgent return to the operating room for control of haemorrhage (Kolsen-Petersen 2004); one because of a transfer to another hospital (Kolsen-Petersen 2004) and one without a reason specified (Durasnel 1999). One enrolled patient failed to complete the protocol but neither the reason nor the group were specified (Ishikawa 1996).

\section{Intention-to-treat analysis}

No patients who completed the protocol were lost to follow up and intention-to-treat analysis was used in all studies.

\section{Effects of interventions}

\section{Primary outcomes}

\section{Mortality}

All trials were presumed to have reported all deaths because other outcomes such as serum sodium were reported at the end of the study period. Only two deaths were reported by the included trials for an overall survival rate of $99.7 \%$. Both deaths occurred in one trial, one in each group (Shackford 1983).

\section{Organ failure}

No episodes of organ failure were reported by any of the included trials.

\section{Secondary outcomes}

\section{Fluid balance}

(Analysis 3.1; Analysis 3.2; Analysis 3.3; Analysis 3.4; Analysis 3.5)

Perioperative fluid balance was calculated in five trials with 230 participants (Bruegger 2005; Cross 1989; Jarvela 2001; Shackford 1983; Shackford 1987). Overall, the fluid balance was positive in both groups but this positive balance was significantly less with HS administration than with IS administration (SMD -1.43L, 95\% confidence interval (CI) 0.8 to $2.1 \mathrm{~L}$ less; $\mathrm{P}<0.00001 ; \mathrm{I}^{2}$ $=76 \%)$. Subgroup analysis suggested no significant effect of the type of surgery (Analysis 3.1), dose of HS given (Analysis 3.2), the total volume of fluid transfused (Analysis 3.3) or study quality (Analysis 3.4). Actual fluid balance (Analysis 3.5) was reported by four trials with 158 participants (Bruegger 2005; Cross 1989; Shackford 1983; Shackford 1987). The positive fluid balance was significantly less in the HS group compared to the IS group (SMD $-1.63 \mathrm{~L}, 95 \%$ CI 0.9 to $2.3 \mathrm{~L}$ less; $\mathrm{P}<0.00001 ; \mathrm{I}^{2}=69 \%$ ), a result almost identical to the calculated balance.

\section{Intravenous fluid volume administered}

(Analysis 4.1; Analysis 4.2; Analysis 4.3)

The volume of intravenous fluid administered to patients was reported in six trials with 270 patients (Bruegger 2005; Cross 1989; Jarvela 2001; Shackford 1983; Shackford 1987) Patients in the HS group received considerably less fluid intravenously than patients in the IS groups (SMD -2.4L 95\% (CI) 1.5 to 3.2 less; P $\left.<0.00001 ; \mathrm{I}^{2}=90 \%\right)$. The high degree of heterogeneity for this outcome was not explained by subgroup analysis according to type of surgery (Analysis 4.1) or the dose of HS (Analysis 4.2). Funnel plot analysis showed this outcome to cluster symmetrically (Figure 2) except for two outliers from studies (Shackford 1983, Shackford 1987) that used considerably more HS than other trials. However, exclusion of these two trials from the analysis did not eliminate heterogeneity. Total fluid transfusion in IS groups exceeded that in HS groups for each subgroup analysed. Sensitivity analysis by 
study quality (Analysis 4.3) did not alter the outcome. No heterogeneity was seen in the two studies where quality was graded as A but it was present in the other groups.

Figure 2. Funnel plot of comparison: 4 Total volume of crystalloid administered (L), outcome: 4.3 Volume of crystalloid administered (sensitivity analysis by study quality).

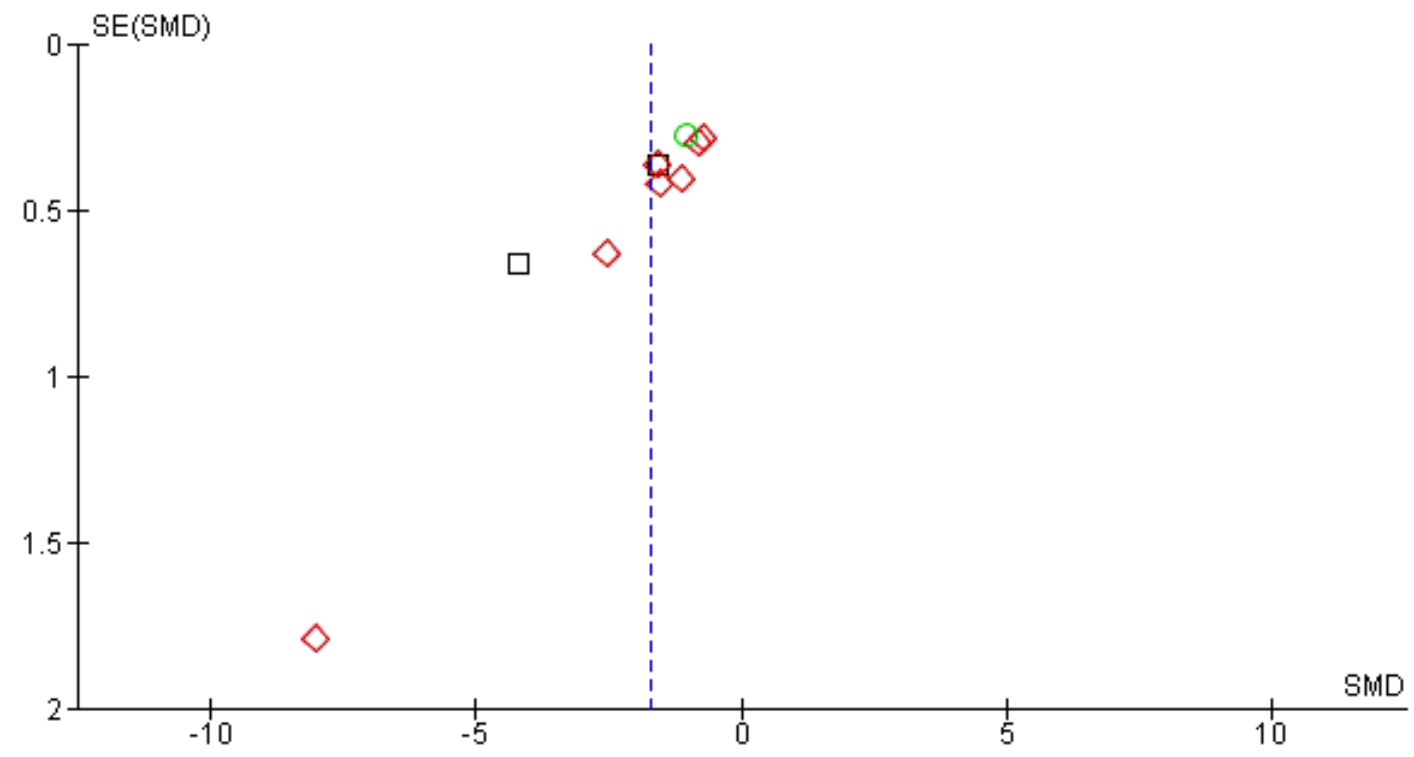

Subgroups

Study grade $=$ A

Study group $=\mathrm{B}$

Study grade $=\mathrm{D}$

\section{Perioperative diuresis}

(Analysis 5.1; Analysis 5.2; Analysis 5.3; Analysis 5.4; Analysis 5.5)

Urine output during the trial was reported in six trials including 270 participants (Bruegger 2005; Cross 1989; Jarvela 2000; Jarvela 2001; Shackford 1983; Shackford 1987). There was no difference in perioperative urine output between the two groups; ( Analysis 5.1 SMD +0.2 L, (95\% CI -0.2 to +0.6$\left.), \mathrm{P}=0.78, \mathrm{I}^{2}=68 \%\right)$. Stratification by type of surgery (Analysis 5.1) or dose of HS ( Analysis 5.2) did not affect the degree of heterogeneity. However heterogeneity was eliminated when the trials were stratified by the total volume of crystalloid use in the IS group (Analysis 5.4). Sensitivity analysis by study quality (Analysis 5.5) did not change the outcome or the heterogeneity of the studies.

\section{Maximum serum sodium}

(Analysis 6.1; Analysis 6.2; Analysis 6.3; Analysis 6.4)

The maximum serum sodium was measured in all of the trials except one (Durasnel 1999), and included 532 participants. Maximum serum sodium was higher in the HS group than the IS group (SMD $+2.24 \mathrm{meq} / \mathrm{L}$ more with $\mathrm{HS}, 95 \% \mathrm{CI} 1.6$ to 2.9 , $\left.\mathrm{P}<0.00001, \mathrm{I}^{2}=88 \%\right)$. The maximum serum sodium ranged between 136 and 159 in HS groups compared to between 137 and $143 \mathrm{meq} / \mathrm{L}$ in the IS groups. The maximum serum sodium was higher with HS in each subgroup. Subgroup analysis by type of surgery (Analysis 6.1) or by volume of crystalloid administered (Analysis 6.3) did not alter the outcome or the heterogeneity between trials. Stratification of subgroups by dose of HS (Analysis 6.2) showed the increase in peak serum sodium with HS to be related to the dose of HS administered (MD +3.6 meq/L, $95 \%$ 
CI 2.6 to 4.8 where the dose equivalent of $3 \% \mathrm{HS}$ was $7 \mathrm{ml} / \mathrm{kg}$ or less compared to MD $+9.98 \mathrm{meq} / \mathrm{L}, 95 \%$ CI 6.1 to 13.9 where dose was $>7 \mathrm{ml} \mathrm{3 \%} \mathrm{HS/kg).} \mathrm{Funnel} \mathrm{plot} \mathrm{analysis} \mathrm{which} \mathrm{showed}$ peak serum sodium of each study to cluster symmetrically around a positive MD in the HS group illustrates the relationship between dose of HS and increase in peak sodium (Figure 3). Sensitivity analysis by study quality did not change the outcome or the heterogeneity of the studies (Analysis 6.4).

Figure 3. Funnel plot of comparison: 6 Peak serum sodium (meq/L), outcome: 6.2 Peak serum sodium (stratified by dose of HS).

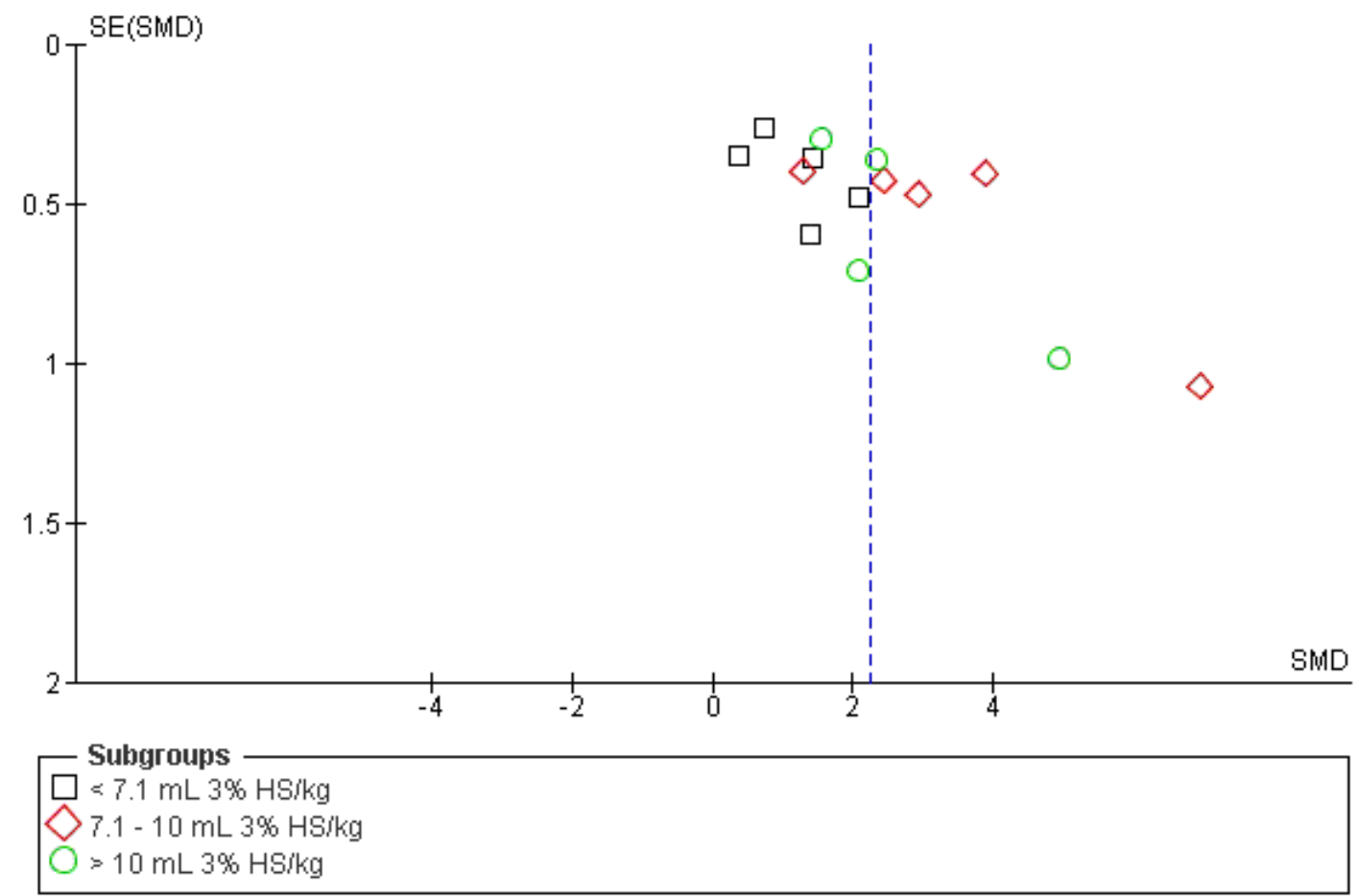

\section{Final serum sodium}

(Analysis 7.1; Analysis 7.2; Analysis 7.3; Analysis 7.4; Analysis 7.5)

By the end of the study period the difference between the groups in serum sodium was considerably reduced (SMD $1.07 \mathrm{meq} / \mathrm{L}$ higher with HS, $95 \%$ CI 0.6 to $1.5, \mathrm{P}<0.00001, \mathrm{I}^{2}=90 \%$ ) and the range for average final serum sodium was within normal limits: 136 to $146 \mathrm{meq} / \mathrm{L}$ and 136 to 140 in the HS and IS groups respectively (Analysis 7.1). Neither the outcome nor heterogeneity were altered in subgroup analysis by surgery type (Analysis 7.4), dose of HS (Analysis 7.2) or volume of crystalloid (Analysis 7.3). Funnel plot analysis is similar to that observed with peak serum sodium except that the difference between HS and IS has been reduced (Figure 4). 
Figure 4. Funnel plot of comparison: 7 Final serum sodium (meq/L), outcome: 7.2 Final serum sodium (stratified by dose of HS given).

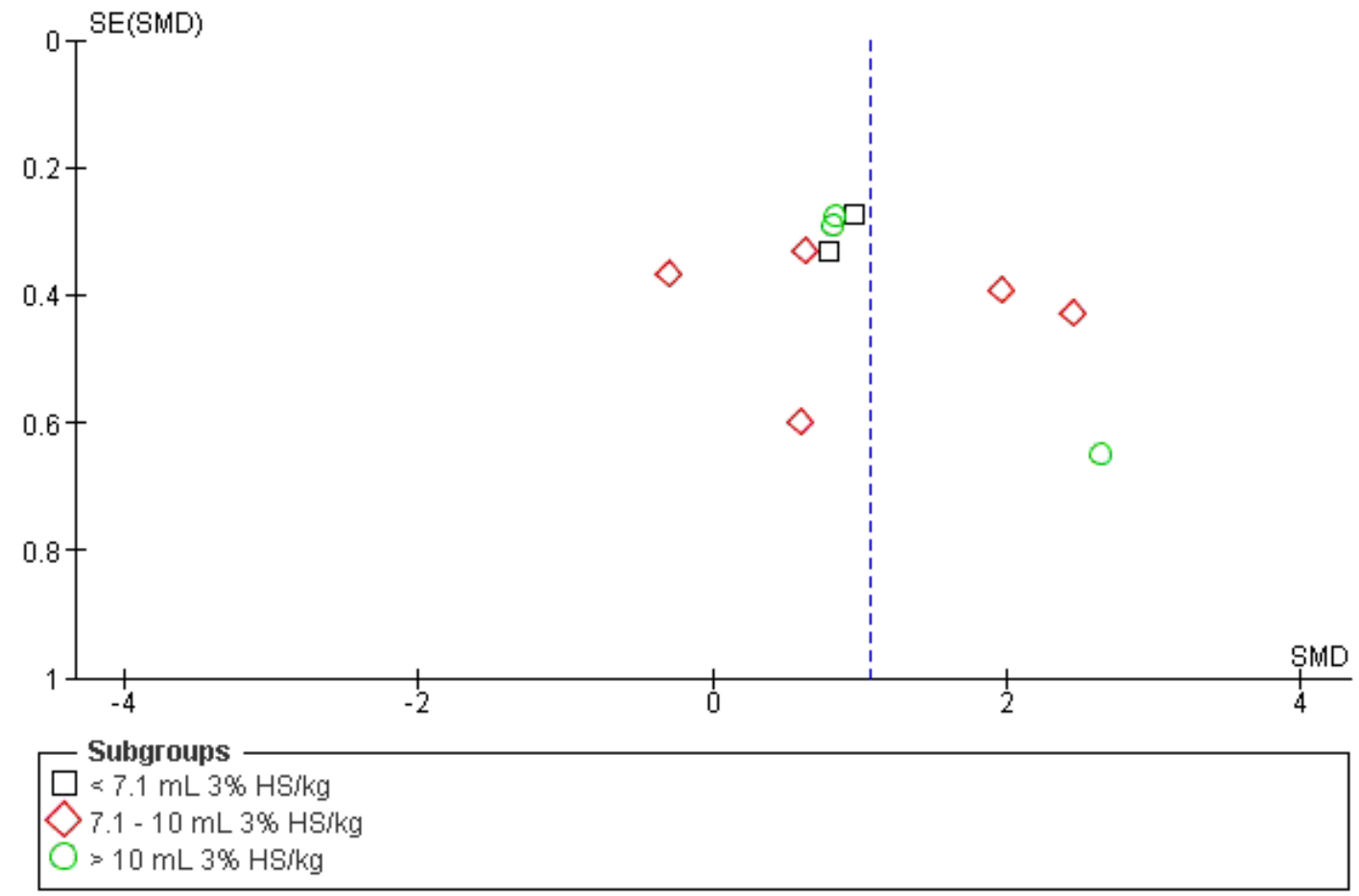

\section{8-10. Duration of endotracheal intubation, intensive care stay and hospital stay}

The duration of mechanical ventilation and the length of stay in hospital were not reported in any of the trials. Only one trial ( Cross 1989) reported the length of stay in intensive care with mean stays (standard deviation) of $2.3(0.2)$ versus $2.4(0.6)$ days in the $\mathrm{HS}$ ans IS groups respectively $(\mathrm{P}=0.63)$.

\section{Adverse events}

No serious adverse events such as myocardial infarction, cerebrovascular accident or central pontine myelinolysis were reported in these trials.

\section{I2. Serum osmolarity, haemodynamic parameters}

(Analysis 12.1; Analysis 12.2; Analysis 12.3)

Trials in which maximum serum osmolarity (Analysis 12.1) was measured (Ishikawa 1996; Jarvela 2000; Jarvela 2001; Kato 1996; Kimura 1994; Kolsen-Petersen 2004; Shackford 1983; Shackford 1987; Younes 1988) showed an increase with HS that was similar to the increase in serum sodium (SMD $2.7 \mathrm{mOsm} / \mathrm{kg} \mathrm{H} 2 \mathrm{O}$ higher with HS, 95\% CI 1.7 to $3.7, \mathrm{P}<0.00001, \mathrm{I}^{2}=90 \%$ ). Several groups measured haemodynamic parameters (Cross 1989; Jarvela 2000; Jarvela 2001; Shackford 1983; Shackford 1987). Maximum intraoperative cardiac index (Analysis 12.3) was significantly increased with HS (SMD 0.6 L/min/M2 higher with HS, 95\% CI 0.1 to $\left.1.0, \mathrm{P}=0.02, \mathrm{I}^{2}=59 \%\right)$ but intraoperative pulmonary artery wedge pressure (Analysis 12.2) remained unchanged by HS (SMD 0, $95 \%$ CI -0.3 to $+0.3, \mathrm{P}=0.98, \mathrm{I}^{2}=0$ ).

\section{DISCUSSION}

There were no differences with respect to mortality or major morbidity between the treatment arms of this meta-analysis. A preliminary survey carried out before designing this meta-analysis suggested that trials of perioperative HS were usually designed to measure fluid volumes, haemodynamics and biochemistry rather than measure important clinical outcomes. Despite this, we chose mortality as the primary outcome for this review and we collected serious adverse event data because of their clinical importance. As 
expected, we found no trials that were designed to measure differences in mortality or serious adverse events and in general the study periods of the included trials were insufficient to determine the impact of the interventions on mortality. Only one death and no organ failures were reported in 297 patients who received HS, just as in the IS group. Neither the trials nor the meta-analysis are sufficiently powered to determine the impact of HS on perioperative mortality or morbidity. The low mortality rate in the IS group suggests that normal risk patients were studied and in which adequate power would require many times the number of patients collected in this meta-analysis. However the absence of excess mortality or morbidity in the HS group despite a wide range of doses administered suggests that HS is safe. Therefore an alternative strategy for consideration is to study perioperative HS in a population at higher risk of death or major morbidity.

Meta-analysis of the outcomes measured by the trials was performed on less clinically relevant outcomes in order to provide a picture of the impact of HS on perioperative fluid management. HS significantly reduces the positive fluid balance experienced by patients undergoing surgery. This observation was independent of the type of surgery or perioperative fluid protocol. HS conserved fluid at lower doses as much as at higher doses.

The principal barrier to meta-analysis of some outcomes is a high degree of heterogeneity between the trials. Heterogeneity appears to be due to differences in the magnitude of the effect observed rather than differences in the effect itself. Subgroup analysis identified sources of heterogeneity in some instances. For example, considerable heterogeneity was observed in perioperative diuresis even though there was no significant difference in diuresis between the test group, HS, and the control. Stratification by the volume of intravenous fluid eliminated heterogeneity. This makes clinical sense in that diuresis is directly related to the volume of fluid infused. It also highlights the variability in the fluid regimen used in these trials. While such variability increases the clinical applicability of the review, it also contributes to heterogeneity of the observations. Other potential sources of heterogeneity such as concommitant medications were not amenable to investigation because of lack of information.

Perioperative diuresis was similar in the HS and IS patients suggesting that adequate intravascular volumes were maintained throughout surgery despite the fact that HS patients received significantly less intravenous fluid than IS patients. HS increased the intraoperative cardiac index. All of the patient groups completed surgery with a positive fluid balance. In some trials, the positive fluid balance was almost $10 \mathrm{~L}$ by the end of surgery. Pulmonary oedema was not recorded in the trials but it is reasonable to be concerned that excess fluid of this magnitude would result in pulmonary oedema in a population at risk of this complication. Use of HS significantly reduced the positive fluid balance experienced by all patients undergoing surgery. HS increased serum sodium and osmolarity in a dose related manner. The doses of HS varied con- siderably between trials, but even in those who received very high doses of HS, no adverse events related to hypernatraemia were encountered. Serum sodium returned to normal limits by the end of the study.

Is there a potential therapeutic window for HS in patients undergoing surgery, where perioperative weight gain can be minimized without a risk of significant hypernatraemia?In hyponatraemic patients, the risk of central pontine myelinolysis is thought to be related to underlying conditions more than the rate of electrolyte repletion but increases in serum sodium of more than $10 \mathrm{meq} / \mathrm{L}$ per day should be avoided if possible (Kumar 2006). It is not known if patients with normal serum sodium are at a similar risk of hyperosmotically induced demyelination. No episodes of central pontine myelinolysis were reported in these studies where the patients had normal serum sodium levels at baseline and we did not find any case reports in the literature of central pontine myelinolysis in patients who received HS. Hypernatraemia is transient after administration of HS. However, it would seem prudent to avoid large increases in serum sodium. This is possible, with these studies suggesting that up to $10 \mathrm{ml} / \mathrm{kg}$ of $3 \% \mathrm{HS}$ will reduce the positive fluid balance perioperatively by up to $1.5 \mathrm{~L}$ in the average adult without increasing serum sodium inappropriately. There is insufficient evidence to determine if such a reduction in perioperative fluid excess would improve clinically relevant outcomes but it provides the basis for an RCT.

\section{A U THORS, CONCLUSIONS Implications for practice}

Small volumes of HS reduced the positive fluid balance and transiently increased serum sodium in patients undergoing surgery. The impact of HS on clinically relevant outcomes was not tested by the trials analysed and we cannot recommend routine perioperative use of HS across the surgical population. HS may be useful when fluid restriction is required in selected individuals or clinical situations.

\section{Implications for research}

HS administration to patients undergoing surgery should be compared to standard practice using RCTs of high methodological rigour in order to determine any impact on patient survival and other clinically relevant outcomes. Sample size estimation is problematic given the very low reported incidence of mortality or significant morbidity in the control group in these trials. The duration of any future trial should be sufficient to cover the period of perioperative mortality or major morbidity which is usually considered to be 60 days or at least the postoperative hospital stay.

\section{ACKNOWLEDG EMENTS}


We would like to thank Associate Professor Mike Bennett (content editor), Dr Harald Herkner (statistical editor) Dr Thomas Schricker, Dr Birgitte Brandstrup (peer reviewers) and Rosemary Doolan (consumer) for their help and editorial advice during the preparation of the protocol and review; Mark Edward, Kathie Godfrey and Nete Villebro for their help and editorial advice during the preparation of the protocol for the review; Mr Karen Hovhannisyan, Trials Search Co-ordinator of the Cochrane Anaesthesia Review Group, for advice regarding electronic searches; Dr Hideaki Tanaka, Ms Christiane Baldwin and Dr Yoshihisa Morita for translations; and Mrs Jane Cracknell, Managing Editor of the Cochrane Anaesthesia Review Group, for patient guidance throughout the whole process.

\section{R E F E R E N C E S}

\section{References to studies included in this review}

Baraka 1994 \{published data only\}

* Baraka A, Taha S, Ghabach M, Sibaii A, Nader A, Matta M. Hypertonic saline prehydration in patients undergoing transurethral resection of the prostate under spinal anaesthesia. British Journal of Anaesthesia 1994;72(2):227-8. [MEDLINE: 7832822]

Bruegger 2005 \{published data only\}

* Bruegger D, Bauer A, Rehm M, Niklas M, Jacob M, Irlbeck M, et al.Effect of hypertonic saline dextran on acid-base balance in patients undergoing surgery of abdominal aortic aneurysm. Critical Care Medicine 2005;33(3):556-63. [MEDLINE: 15753747]

Cross 1989 \{published data only\}

* Cross JS, Gruber DP, Burchard KW, Singh AK, Moran JM, Gann DS. Hypertonic saline fluid therapy following surgery: a prospective study. The Journal of Trauma 1989;29(6):817-25. [MEDLINE: 2661843]

Cross JS, Gruber DP, Gann DS, Singh AK, Moran JM, Burchard $\mathrm{KW}$. Hypertonic saline attenuates the hormonal response to injury. Annals of Surgery 1989;209(6):684-91. [MEDLINE: 2543337]

\section{Durasnel 1999 \{published data only\}}

* Durasnel P, Cresci L, Madougou M, Idrissa A, Cheriff I, Falandry $\mathrm{L}$, et al.Practice of spinal anesthesia in a developing country: usefulness of vascular preloading with a $7.5 \%$ hypertonic saline solution [Pratique de la rachianesthesie dans un pays en voie de development: interet du remplissage vasculaire par un solute sale hypertonique a 7,5\%]. Annales francaises d'anesthesie et de reanimation. 1999;18(6):631-5. [MEDLINE: 10464529]

Ishikawa 1996 \{published data only\}

Ishikawa $\mathrm{G}$. The effect of hypertonic saline infusion on lumbar epidural anesthesia. Masui 1996;45(2):205-14. [MEDLINE: 8865710]

Jarvela 2000 \{published data only\}

Jarvala K. Email correspondence (January 4, 2007) 2007.

* Jarvela K, Honkonen SE, Jarvela T, Koobi T, Kaukinen S. The comparison of hypertonic saline (7.5\%) and normal saline $(0.9 \%)$ for initial fluid administration before spinal anaesthesia. Anesthesia and Analgesia 2000;91:1461-5.

Jarvela K, Koobi T, Kauppinen P, Kaukinen S. Effects of hypertonic $75 \mathrm{mg} / \mathrm{ml}(7.5 \%)$ saline on extracellular water volume when used for preloading before spinal anaesthesia. Acta Anaesthesiologica Scandinavica 2001;45(6):776-81. [MEDLINE: 11421840]

Jarvela 2001 \{published data only\}

Jarvala K. Email correspondence (January 4, 2007) 2007. Jarvela K, Kaukinen S. Hypertonic saline (7.5\%) after coronary artery bypass grafting. European Journal of Anaesthesiology 2001;18 (2):100-7. [MEDLINE: 11270018]

* Jarvela K, Kaukinen S. Hypertonic saline (7.5\%) decreases perioperative weight gain following cardiac surgery. Journal of Cardiothoracic and Vascular Anesthesia 2002;16(1):43-6. [MEDLINE: 11854877]

Jarvela K, Koskinen M, Kaukinen S, Koobi T. Effects of hypertonic saline $(7.5 \%)$ on extracellular fluid volumes compared with normal saline $(0.9 \%)$ and $6 \%$ hydroxyethyl starch after aortocoronary bypass graft surgery. Journal of Cardiothoracic and Vascular Anesthesia 2001;15(2):210-5. [MEDLINE: 11312481]

\section{Kato 1996 \{published data only\}}

${ }^{*}$ Kato S, Goto F. Hypertonic saline for intraoperative fluid therapy in transurethral resection of the prostate. Journal of Anesthesia 1996; 10:170-5.

\section{Kimura 1994 \{published data only\}}

${ }^{*}$ Kimura K, Takaori M. The effects of hypertonic lactated Ringer's solution during transurethral surgery. Masui. The Japanese Journal of Anesthesiology 1994;43(8):1141-7.

\section{Kolsen-Petersen 2004 \{published data only\}}

Kolsen-Petersen JA, Nielsen JO, Bendtzen K, Tonnesen E. Infusion of hypertonic saline $(7.5 \% \mathrm{NaCl})$ causes minor immunological changes in normovolaemic women. Acta Anaesthesiology Scandinavica 2004;48(2):224-33. [MEDLINE: 14995946]

* Kolsen-Petersen JA, Nielsen JO, Tonnesen EM. Effect of hypertonic saline infusion on postoperative cellular immune 
function: a randomized controlled clinical trial. Anesthesiology 2004;100(5):1108-1118. [MEDLINE: 15114207]

Kolsen-Petersen JA, Rasmussen TB, Krog J, Hokland M, Tonnesen EK. Infusion of hypertonic saline (7.5\%) does not change neutrophil oxidative burst or expression of endothelial adhesion molecules after abdominal hysterectomy. Journal of Trauma 2006; 61(5):1100-6. [MEDLINE: 17099514]

Shackford 1983 \{published data only\}

* Shackford SR, Sise MJ, Fridlund PH, Rowley WR, Peters RM,

Virgilio RW, et al.Hypertonic sodium lactate versus lactated ringer's solution for intravenous fluid therapy in operations on the abdominal aorta. Surgery 1983;94:41-51.

Shackford 1987 \{published data only\}

* Shackford SR, Fortlage DA, Peters RM, Hollingsworth-Fridlund P, Sise MJ. Serum osmolar and electrolyte changes associated with large infusions of hypertonic sodium lactate for intravascular volume expansion of patients undergoing aortic reconstruction. Surgery, Gynecology and Obstetrics 1987;164:127-36. [MEDLINE: 3810427]

Veroli 1992 \{published data only\}

* Veroli P, Benhamou D. Comparison of hypertonic saline (5\%), isotonic saline and ringer's lactate solutions for fluid preloading before lumbar extradural anaesthesia. British Journal of Anaesthesia 1992;69:461-4.

Wang 1997 \{published data only\}

Wang BW, Chiou YH, Chen WB, Peng TY, Leung HK. Intravenous pretreatment of hypertonic saline can prevent systemic hypotension induced by spinal anesthesia. Acta Anaesthesiologica Sinica 1997;35(2):85-90. [MEDLINE: 9293648]

\section{Younes 1988 \{published data only\}}

* Younes RN, Bechara MJ, Langer B, Aun F, Birolini D, Kuznieck $S$, et al.Use of a hypertonic solution of $7.5 \% \mathrm{NaCl}$ in preventing post-declamping hypotension of the abdominal aorta [Emprego da solucao hipertonica de $\mathrm{NaCl}$ a 7,5\% na prevencao do hipotensao pos-desclampeamento da aorta abdominal]. Revista da Associacao Medica Brasileira 1988;34(5):150-4. [MEDLINE: 3251309]

\section{References to studies excluded from this review}

Auler 1987 \{published data only\}

* Auler JOC, Pereira MHC, Gomide-Amaral RV, Stolf NG, Jatene $\mathrm{AD}$, Rocha e Silva M. Hemodynamic effects of hypertonic sodium chloride during surgical treatment of aortic aneurysms. Surgery 1987;101:594-601.

Auler 1992 \{published data only\}

* Auler JOC, Zin WA, Martins MA, Younes RN, Negri EM, Hoelz $\mathrm{C}$, et al.Respiratory system mechanics in patients treated with isotonic or hypertonic $\mathrm{NaCl}$ solutions. Circulatory Shock 1992;36: 243-8.

Shao 2005 \{published data only\}

Shao YS, Zhang YT, Peng KQ, Quan ZY. Effects of 7.5\% hypertonic saline on fluid balance after radical surgery for gastrointestinal carcinoma. World Journal of Gastroenterology 2005; 11(11):1577-81. [MEDLINE: 15786530]

\section{Additional references}

\section{Arkilic 2003}

Arkilic CF, Taguchi A, Sharma N, Ratnaraj J, Sessler DI, Read TE, et al.Supplemental perioperative fluid administration increases tissue oxygen pressure. Surgery 2003;133:49-55. [MEDLINE: 12563237]

Brandstrup 2003

Brandstrup B, Tonnesen H, Beier-Holgersen R, Hjortso E, Ording $\mathrm{H}$, Lindorff-Larsen K, et al: Danish Study Group on Perioperative Fluid Therapy. Effects of intravenous fluid restriction on postoperative complications: comparison of two perioperative fluid regimens: a randomized assessor-blinded multicenter trial. Annals of Surgery 2003;238:641-8. [MEDLINE: 14578723]

\section{Bunn 2004}

Bunn F, Roberts I, Tasker R, Akpa E. Hypertonic versus near isotonic crystalloid for fluid resuscitation in critically ill patients. Cochrane Database of Systematic Reviews 2004, Issue 3. [DOI: 10.1002/14651858.CD002045.pub2; MEDLINE: 15266460]

DerSimonian 1986

DerSimonian R, Laird N. Meta-analysis in clinical trials. Controlled Clinical Trials 1986;7:177-88. [MEDLINE: 3802833]

\section{Grocott 2005}

Grocott MP, Mythen MG, Gan TJ. Perioperative fluid management and clinical outcomes in adults. Anesthesia and Analgesia 2005;100(4):1093-106. [MEDLINE: 15781528]

Higgins 2002

Higgins JP, Thompson SG. Quantifying heterogeneity in a metaanalysis. Statistics in Medicine 2002;15(21):1539-58.

\section{Higgins 2008}

Higgins JPT, Green S (editors). Cochrane Handbook for Systematic Reviews of Interventions Version 5.0.1 [updated September 2008]. The Cochrane Collaboration, 2008. Available from www.cochrane-handbook.org.

\section{Kumar 2006}

Kumar S, Fowler M, Gonzalez-Toledo E, Jaffe SL. Central pontine myelinolysis, an update. Neurological Research 2006;28(3):360-6. [MEDLINE: 16687066]

\section{Lobo 2002}

Lobo DN, Bostock KA, Neal KR, Perkins AC, Rowlands BJ, Allison SP. Effect of salt and water balance on recovery of gastrointestinal function after elective colonic resection: a randomised controlled trial. Lancet 2002;359:1812-8. [MEDLINE: 12044376]

\section{Ogden 2005}

Ogden AT, Mayer SA, Connolly ES Jr. Hyperosmolar agents in neurosurgical practice: the evolving role of hypertonic saline. Neurosurgery 2005;57(2):207-15. [MEDLINE: 16094147]

\section{RevMan 5.0}

The Nordic Cochrane Centre, The Cochrane Collaboration. Review Manager (RevMan). 5.0. Copenhagen: The Nordic Cochrane Centre, The Cochrane Collaboration, 2008.

\section{Rizoli 2006}

Rizoli SB, Rhind SG, Shek PN, Inaba K, Filips D, Tien H, et al.The immunomodulatory effects of hypertonic saline resuscitation in patients sustaining traumatic hemorrhagic shock: a randomized, controlled, double-blinded trial. Annals of surgery 2006;243(1): 47-57. [MEDLINE: 16371736] 


\section{Wade 1997}

Wade CE, Kramer GC, Grady JJ, Fabian TC, Younes RN. Efficacy of hypertonic $7.5 \%$ saline and $6 \%$ dextran-70 in treating trauma: a meta-analysis of controlled clinical studies. Surgery 1997;122(3): 609-16. [MEDLINE: 9308620]

* Indicates the major publication for the study 
CHARACTERISTICS OF STUDIES

\section{Characteristics of included studies [ordered by study ID]}

Baraka 1994

\begin{tabular}{|c|c|}
\hline Methods & $\begin{array}{l}\text { Publication type: full article } \\
\text { Allocation random: yes } \\
\text { Allocation concealment: not described } \\
\text { Baseline comparison: yes } \\
\text { Baseline similarity: yes } \\
\text { Blinding of care givers: yes } \\
\text { Additional features to blind fluid administered: no } \\
\text { Control of co-interventions: yes } \\
\text { Completeness of follow-up: yes } \\
\text { Intention-to-treat analysis: yes }\end{array}$ \\
\hline Participants & $\begin{array}{l}\text { Country: Lebanon } \\
\text { Language: English } \\
\text { Single centre } \\
\text { Inclusion criteria: consenting adult male patients undergoing transurethral resection of the prostate under } \\
\text { spinal anaesthesia } \\
\text { Exclusion criteria: ASA IV } \\
\text { Number eligible: not specified } \\
\text { Number enrolled: } 33 \text { (HS 17; NS 16) } \\
\text { Number completed study: } 33\end{array}$ \\
\hline Interventions & $\begin{array}{l}\text { Hypertonic saline group } \\
\text { IV solution: } 3 \% \mathrm{HS} \\
\text { Dose: } 7 \mathrm{ml} / \mathrm{kg} \\
\text { Duration: before spinal anaesthesia } \\
\text { Isotonic salt solution group } \\
\text { IV solution: NS } \\
\text { Dose: } 7 \mathrm{ml} / \mathrm{kg} \\
\text { Duration: before spinal anaesthesia } \\
\text { Co-interventions: } \\
\text { Co-interventions applied differentially between groups: no } \\
\text { Study Period: duration of surgery }\end{array}$ \\
\hline Outcomes & $\begin{array}{l}\text { Mortality } \\
\text { Peak serum sodium } \\
\text { Haemodynamic parameters }\end{array}$ \\
\hline Notes & \\
\hline \multicolumn{2}{|l|}{ Risk of bias } \\
\hline Item & Authors' judgement \\
\hline
\end{tabular}


Baraka 1994 (Continued)

\begin{tabular}{l|l}
\hline Allocation concealment? & Unclear \\
\hline
\end{tabular}

\section{Bruegger 2005}

\begin{tabular}{|c|c|}
\hline Methods & $\begin{array}{l}\text { Publication type: full article } \\
\text { Allocation random: yes } \\
\text { Allocation concealment: not described } \\
\text { Baseline comparison: yes } \\
\text { Baseline similarity: yes } \\
\text { Blinding of care givers: no } \\
\text { Additional features to blind fluid administered: no } \\
\text { Control of co-interventions: no } \\
\text { Completeness of follow-up: yes } \\
\text { Intention-to-treat analysis: yes }\end{array}$ \\
\hline Participants & $\begin{array}{l}\text { Country: Germany } \\
\text { Language: English } \\
\text { Single centre } \\
\text { Inclusion criteria: patients undergoing elective infrarenal aortic aneurysm repair } \\
\text { Exclusion criteria: ASA IV; renal dysfunction; congestive heart failure; recent brain infarction; contra- } \\
\text { indication to starch or dextran } \\
\text { Number eligible: Not specified } \\
\text { Number enrolled: } 28 \text { (HS 14; NS 14) } \\
\text { Number completed study: } 28\end{array}$ \\
\hline Interventions & $\begin{array}{l}\text { Hypertonic saline group } \\
\text { IV solution: } 7.5 \% \mathrm{NaCl} \\
\text { Dose: } 250 \mathrm{ml} \\
\text { Isotonic salt solution group } \\
\text { IV solution: NS } \\
\text { Dose: } 250 \mathrm{ml} \\
\text { Co-interventions: dextran } 70 \text { given with HS; hydroxyethyl starch given with NS } \\
\text { Co-interventions applied differentially between groups: yes } \\
\text { Study Period: duration of surgery plus } 72 \text { hours }\end{array}$ \\
\hline Outcomes & $\begin{array}{l}\text { Mortality } \\
\text { Fluid volume transfused } \\
\text { Blood transfused } \\
\text { Fluid loss } \\
\text { Fluid balance } \\
\text { Peak serum sodium } \\
\text { Urine output } \\
\text { Haemodynamic parameters }\end{array}$ \\
\hline Notes & Different colloids given to experimental and control groups \\
\hline
\end{tabular}

Risk of bias 
Bruegger 2005 (Continued)

\begin{tabular}{l|ll}
\hline Item & Authors' judgement & Description \\
\hline Allocation concealment? & Unclear & B - Unclear \\
\hline
\end{tabular}

Cross 1989

Methods

Publication type: full article

Allocation random: yes

Allocation concealment: not described

Baseline comparison: yes

Baseline similarity: yes

Blinding of care givers: yes

Additional features to blind fluid administered: no

Control of co-interventions: yes

Completeness of follow-up: yes

Intention-to-treat analysis: yes

\begin{tabular}{ll} 
Participants & Country: USA \\
& Language: English \\
& Inclusion criteria: consenting patients undergoing coronary artery bypass \\
Exclusion criteria: cardiac arrhythmia; cardiac, pulmonary, renal, hepatic failure & Number eligible: not given \\
Number enrolled: 20 (HS 11; ISS 9) \\
Number completed study: 20 \\
\hline
\end{tabular}

\begin{tabular}{|c|c|}
\hline Interventions & $\begin{array}{l}\text { Hypertonic saline group } \\
\text { IV solution: HS }(1.8 \%, 304 \text { meq } \mathrm{Na} / \mathrm{L}) \\
\text { Dose: } 100 \mathrm{cc} / \text { hour } \\
\text { Duration: Postoperative admission to ICU for } 24 \text { hours } \\
\text { Subsequent maintenance: } \mathrm{D} 5 / 0.45 \mathrm{NaCl} \text { if serum sodium }>155 \mathrm{meq} / \mathrm{L} \\
\text { Isotonic salt solution group } \\
\text { IV solution: NS } \\
\text { Dose: } 100 \mathrm{cc} / \text { hour } \\
\text { Duration: admission to ICU for } 24 \text { hours } \\
\text { Post-operative maintenance: } \mathrm{D} 5 / 0.45 \mathrm{NaCl} \text { if serum sodium }>155 \mathrm{meq} / \mathrm{L} \\
\text { Co-interventions: } \\
\text { Co-interventions applied differentially between groups: no } \\
\text { Study Period: } 24 \text { hours from the beginning of surgery }\end{array}$ \\
\hline Outcomes & $\begin{array}{l}\text { Mortality } \\
\text { LOS hospital } \\
\text { LOS ICU } \\
\text { Fluid volume transfused } \\
\text { Blood transfused } \\
\text { Fluid loss } \\
\text { Fluid balance } \\
\text { Peak serum sodium } \\
\text { Urine output }\end{array}$ \\
\hline
\end{tabular}


Cross 1989 (Continued)

Haemodynamic parameters

\begin{tabular}{|c|c|c|}
\hline Notes & & \\
\hline \multicolumn{3}{|l|}{ Risk of bias } \\
\hline Item & Authors' judgement & Description \\
\hline Allocation concealment? & Unclear & B - Unclear \\
\hline
\end{tabular}

\section{Durasnel 1999}

\begin{tabular}{|c|c|}
\hline Methods & $\begin{array}{l}\text { Publication type: full article } \\
\text { Allocation random: yes } \\
\text { Allocation concealment: not described } \\
\text { Baseline comparison: yes } \\
\text { Baseline similarity: yes } \\
\text { Blinding of care givers: yes } \\
\text { Additional features to blind fluid administered: no } \\
\text { Control of co-interventions: yes } \\
\text { Completeness of follow-up: yes } \\
\text { Intention-to-treat analysis: yes }\end{array}$ \\
\hline Participants & $\begin{array}{l}\text { Country: Niger } \\
\text { Language: French } \\
\text { Single centre } \\
\text { Inclusion criteria: consenting adult patients undergoing surgery using spinal anaesthesia } \\
\text { Exclusion criteria: systemic infection, coagulopathy, allergy to local anaesthetic, uncorrected hypovolaemia, } \\
\text { congestive heart failure, kidney failure } \\
\text { Number eligible: not specified } \\
\text { Number enrolled: } 50 \text { (HS 25; ISS 25) } \\
\text { Number completed study: } 48 \text { (one from each group excluded, cause not given) }\end{array}$ \\
\hline Interventions & $\begin{array}{l}\text { Hypertonic saline group } \\
\text { IV solution: } 7.5 \% \mathrm{HS} \\
\text { Dose: } 100 \mathrm{ml} \\
\text { Duration: prior to anaesthesia } \\
\text { Isotonic salt solution group } \\
\text { IV solution: } 0.9 \% \mathrm{NaCl} \\
\text { Dose: } 100 \mathrm{ml} \\
\text { Duration: prior to anaesthesia } \\
\text { Co-interventions: } \\
\text { Co-interventions applied differentially between groups: no } \\
\text { Study Period: duration of surgery }\end{array}$ \\
\hline Outcomes & $\begin{array}{l}\text { Mortality } \\
\text { Haemodynamic parameters } \\
\text { Fluid volume transfused }\end{array}$ \\
\hline
\end{tabular}


Durasnel 1999 (Continued)

Notes

Risk of bias

\begin{tabular}{l|ll}
\hline Item & Authors' judgement & Description \\
\hline Allocation concealment? & Unclear & B - Unclear \\
\hline
\end{tabular}

Ishikawa 1996

Methods

Publication type: full article

Allocation random: unclear

Allocation concealment: not described

Baseline comparison: yes

Baseline similarity: yes

Blinding of care givers: no

Additional features to blind fluid administered: no

Control of co-interventions: yes

Completeness of follow-up: no (one patient in RL group excluded during study)

Intention-to-treat analysis: yes

\begin{tabular}{|c|c|}
\hline Participants & $\begin{array}{l}\text { Country: Japan } \\
\text { Language: Japanese } \\
\text { Inclusion criteria: Patients undergoing lower limb or pelvic surgery with epidural anaesthesia } \\
\text { Exclusion criteria: ASA classification II, III or IV; MAP decrease by } 50 \mathrm{~mm} \mathrm{Hg} \\
\text { Number eligible: } 24 \\
\text { Number enrolled: } 24 \\
\text { Number completed study: } 23\end{array}$ \\
\hline Interventions & $\begin{array}{l}\text { Hypertonic saline group } \\
\text { IV solution: } 7.2 \% \mathrm{HS} \\
\text { Dose: } 1.8 \mathrm{ml} / \mathrm{kg} \\
\text { Duration: } 20 \text { minute } \\
\text { Post-operative maintenance: ISS } \\
\text { Isotonic salt solution group } \\
\text { IV solution: } \mathrm{NS} \\
\text { Dose: } 1 \text { - } 2 \mathrm{ml} / \mathrm{kg} / \mathrm{hr} \\
\text { Duration: study period } \\
\text { Co-interventions: epidural anaesthesia } \\
\text { Co-interventions applied differentially between groups: no } \\
\text { Study Period: duration of surgery }\end{array}$ \\
\hline Outcomes & $\begin{array}{l}\text { Peak serum sodium } \\
\text { Haemodynamic parameters }\end{array}$ \\
\hline Notes & Translations supplied by Dr Hideaki Tanaka and Dr Yoshihisa Morita \\
\hline
\end{tabular}

\section{Risk of bias}

Hypertonic saline for peri-operative fluid management (Review) 
Ishikawa 1996 (Continued)

\begin{tabular}{l|ll}
\hline Item & Authors' judgement & Description \\
\hline Allocation concealment? & Unclear & B - Unclear \\
\hline
\end{tabular}

Jarvela 2000

\begin{tabular}{|c|c|}
\hline Methods & $\begin{array}{l}\text { Publication type: full article } \\
\text { Allocation random: yes } \\
\text { Allocation concealment: not described } \\
\text { Baseline comparison: yes } \\
\text { Baseline similarity: yes } \\
\text { Blinding of care givers: yes } \\
\text { Additional features to blind fluid administered: no } \\
\text { Control of co-interventions: yes } \\
\text { Completeness of follow-up: yes } \\
\text { Intention-to-treat analysis: yes }\end{array}$ \\
\hline Participants & $\begin{array}{l}\text { Country: Finland } \\
\text { Language: English } \\
\text { Single centre } \\
\text { Inclusion criteria: consenting fit patients have lower limb surgery under spinal anaesthesia } \\
\text { Exclusion criteria: ASA III or IV } \\
\text { Number eligible: not specified } \\
\text { Number enrolled: } 40 \text { (HS 20; ISS 20) } \\
\text { Number completed study: } 40\end{array}$ \\
\hline Interventions & $\begin{array}{l}\text { Hypertonic saline group } \\
\text { IV solution: } 7.5 \% \mathrm{HS} \\
\text { Dose: } 4 \mathrm{ml} / \mathrm{kg} \\
\text { Duration: } 30 \text { minute } \\
\text { Post-operative maintenance: } \mathrm{D} 5 / 0.3 \% \mathrm{NaCl} \text { at } 1 \mathrm{ml} / \mathrm{kg} / \mathrm{hour} \\
\text { Isotonic salt solution group } \\
\text { IV solution: } \mathrm{NS} \\
\text { Dose: } 4 \mathrm{ml} / \mathrm{kg} \\
\text { Duration: } 30 \text { minute } \\
\text { Post-operative maintenance: } \mathrm{D} 5 / 0.3 \% \mathrm{NaCl} \text { at } 1 \mathrm{ml} / \mathrm{kg} / \mathrm{hour} \\
\text { Co-interventions: } \\
\text { Co-interventions applied differentially between groups: no } \\
\text { Study Period: duration of surgery and post-anaesthetic recovery period }\end{array}$ \\
\hline Outcomes & $\begin{array}{l}\text { Mortality } \\
\text { Fluid volume transfused } \\
\text { Fluid loss } \\
\text { Fluid balance } \\
\text { Peak serum sodium } \\
\text { Urine output } \\
\text { Haemodynamic parameters }\end{array}$ \\
\hline
\end{tabular}


Jarvela 2000 (Continued)

Notes

Risk of bias

\begin{tabular}{l|ll}
\hline Item & Authors' judgement & Description \\
\hline Allocation concealment? & Yes & A - Adequate \\
\hline
\end{tabular}

Jarvela 2001

\begin{tabular}{|c|c|}
\hline Methods & $\begin{array}{l}\text { Publication type: full article Allocation random: yes Allocation concealment: not described Baseline com- } \\
\text { parison: yes Baseline similarity: yes Blinding of care givers: no Additional features to blind fluid adminis- } \\
\text { tered: no Control of co-interventions: yes Completeness of follow-up: yes Intention-to-treat analysis: yes }\end{array}$ \\
\hline Participants & $\begin{array}{l}\text { Country: Finland } \\
\text { Language: English } \\
\text { Single centre } \\
\text { Inclusion criteria: Patients undergoing elective coronary artery bypass graft } \\
\text { Exclusion criteria: not specified } \\
\text { Number eligible: not specified } \\
\text { Number enrolled: } 72 \text { (HS } 36 \text {; ISS 36) } \\
\text { Number completed study: } 72\end{array}$ \\
\hline Interventions & $\begin{array}{l}\text { Hypertonic saline group } \\
\text { IV solution: } 7.5 \% \mathrm{HS} \\
\text { Dose: } 4 \mathrm{ml} / \mathrm{kg} \\
\text { Duration: } 30 \text { minute } \\
\text { Post-operative maintenance: } \mathrm{D} 5 / 0.3 \% \mathrm{NaCl} \text { at } 1 \mathrm{ml} / \mathrm{kg} / \text { hour } \\
\text { Isotonic salt solution group } \\
\text { IV solution: NS } \\
\text { Dose: } 4 \mathrm{ml} / \mathrm{kg} \\
\text { Duration: } 30 \text { minute } \\
\text { Post-operative maintenance: D } 5 / 0.3 \% \mathrm{NaCl} \text { at } 1 \mathrm{ml} / \mathrm{kg} / \text { hour } \\
\text { Co-interventions: } 4 \% \text { albumin to maintain cardiac index at } 2.5 \mathrm{~L} / \mathrm{min} / \mathrm{m} 2 \\
\text { Co-interventions applied differentially between groups: no } \\
\text { Study Period: duration of surgery and post-operative period until next morning }\end{array}$ \\
\hline Outcomes & $\begin{array}{l}\text { Mortality } \\
\text { Fluid volume transfused } \\
\text { Weight gain } \\
\text { Fluid loss } \\
\text { Fluid balance } \\
\text { Peak serum sodium } \\
\text { Urine output } \\
\text { Haemodynamic parameters } \\
\text { Extubation times }\end{array}$ \\
\hline
\end{tabular}

Notes 
Jarvela 2001 (Continued)

\section{Risk of bias}

\begin{tabular}{l|ll}
\hline Item & Authors' judgement & Description \\
\hline Allocation concealment? & Yes & A - Adequate \\
\hline
\end{tabular}

\section{Kato 1996}

Methods

Publication type: full article

Allocation random: yes

Allocation concealment: not described

Baseline comparison: yes

Baseline similarity: yes

Blinding of care givers: yes

Additional features to blind fluid administered: no

Control of co-interventions: yes

Completeness of follow-up: yes

Intention-to-treat analysis: yes

\begin{tabular}{ll} 
Participants & Country: Japan \\
& Language: English \\
Inclusion criteria: consenting patients undergoing transurethral resection of the prostate \\
Exclusion criteria: not given \\
Number eligible: not given \\
Number enrolled: 40 (HS 20; ISS 20) \\
Number completed study: 40 \\
\hline
\end{tabular}

\begin{tabular}{ll} 
Interventions & Hypertonic saline group \\
& IV solution: $3 \% \mathrm{HS}$ \\
& Dose: $4 \mathrm{ml} / \mathrm{kg} / \mathrm{min}$ \\
Duration: adjusted to maintain mean arterial pressure at $80 \%$ of preoperative value \\
Isotonic salt solution group \\
IV solution: $\mathrm{RL}$ \\
Dose: $4 \mathrm{ml} / \mathrm{kg} / \mathrm{min}$ \\
Duration: adjusted to maintain mean arterial pressure at $80 \%$ of preoperative value \\
Post-operative maintenance: \\
Co-interventions: \\
Co-interventions applied differentially between groups: no \\
Study Period: duration of surgery plus first post-operative day. \\
\hline Outcomes & $\begin{array}{l}\text { Mortality } \\
\text { Fluid volume transfused } \\
\text { Peak serum sodium }\end{array}$ \\
\hline Haemodynamic parameters
\end{tabular}

\section{Risk of bias}


Kato 1996 (Continued)

\begin{tabular}{l|ll}
\hline Item & Authors' judgement & Description \\
\hline Allocation concealment? & Unclear & B - Unclear \\
\hline
\end{tabular}

\section{Kimura 1994}

Methods

Publication type: full article

Allocation random: unclear

Allocation concealment: not described

Baseline comparison: yes

Baseline similarity: yes

Blinding of care givers: unclear

Additional features to blind fluid administered: no

Control of co-interventions: yes

Completeness of follow-up: yes

Intention-to-treat analysis: unclear

$\begin{array}{ll}\text { Participants } & \text { Country: Japan } \\ & \text { Language: Japanese } \\ & \text { Inclusion criteria: patients undergoing transurethral resection of the prostate, spinal anaesthesia } \\ \text { Exclusion criteria: ASA III, IV; hypertension; diabetes; endocrine disease. } \\ \text { Number eligible: } 14 \\ \text { Number enrolled: } 14 \text { (HS 7; ISS 7) } \\ \text { Number completed study: } 14\end{array}$

\section{Risk of bias}

\begin{tabular}{l|ll}
\hline Item & Author' judgement & Description \\
\hline Allocation concealment? & Unclear & B - Unclear \\
\hline
\end{tabular}


Kolsen-Petersen 2004

\begin{tabular}{|c|c|c|}
\hline Methods & \multicolumn{2}{|c|}{$\begin{array}{l}\text { Publication type: full article } \\
\text { Allocation random: yes } \\
\text { Allocation concealment: not described } \\
\text { Baseline comparison: yes } \\
\text { Baseline similarity: yes } \\
\text { Blinding of care givers: no } \\
\text { Additional features to blind fluid administered: no } \\
\text { Control of co-interventions: yes } \\
\text { Completeness of follow-up: yes } \\
\text { Intention-to-treat analysis: yes }\end{array}$} \\
\hline Participants & \multicolumn{2}{|c|}{$\begin{array}{l}\text { Country: Denmark } \\
\text { Language: English } \\
\text { Inclusion criteria: adult female patients undergoing elective hysterectomy } \\
\text { Exclusion criteria: ASA III or IV; cardiac failure; renal failure; anaemia; diabetes mellitus; certain medica- } \\
\text { tions that effect the immune response } \\
\text { Number eligible: } 192 \text { screened } \\
\text { Number enrolled: } 62 \text { (HS } 21 \text {; NS- } 4 \text { 21; NS-32 20) } \\
\text { Number completed study: } 58 \text { (one HS patient withdrew consent; one HS had anaphylactoid reaction to } \\
\text { anaesthetic agent; one NS-4 patient transferred to another hospital; one NS-32 patient returned to the } \\
\text { operating room for haemorrhage) }\end{array}$} \\
\hline Interventions & \multicolumn{2}{|c|}{$\begin{array}{l}\text { Hypertonic saline group } \\
\text { IV solution: } 7.5 \% \mathrm{NaCl} \\
\text { Dose: } 4 \mathrm{ml} / \mathrm{kg} \\
\text { Duration: over } 10 \text { minutes before hysterectomy } \\
\text { Post-operative maintenance: not specified } \\
\text { Isotonic salt solution group } \\
\text { IV solution: NS } \\
\text { Dose - two groups: 'NS-4' received } 4 \mathrm{ml} / \mathrm{kg} \text {; 'NS-32' received } 32 \mathrm{ml} / \mathrm{kg} \\
\text { Duration: over } 10 \text { minutes before hysterectomy } \\
\text { Post-operative maintenance: not specified } \\
\text { Co-interventions: anaesthesia, analgesia } \\
\text { Co-interventions applied differentially between groups: no } \\
\text { Study Period: duration of surgery plus } 48 \text { hours after closure of the wound. }\end{array}$} \\
\hline Outcomes & \multicolumn{2}{|l|}{$\begin{array}{l}\text { Mortality } \\
\text { Peak serum sodium } \\
\text { Urine output } \\
\text { Immunological parameters }\end{array}$} \\
\hline \multicolumn{3}{|l|}{ Notes } \\
\hline \multicolumn{3}{|l|}{ Risk of bias } \\
\hline Item & Authors' judgement & Description \\
\hline Allocation concealment? & Unclear & B - Unclear \\
\hline
\end{tabular}


Shackford 1983

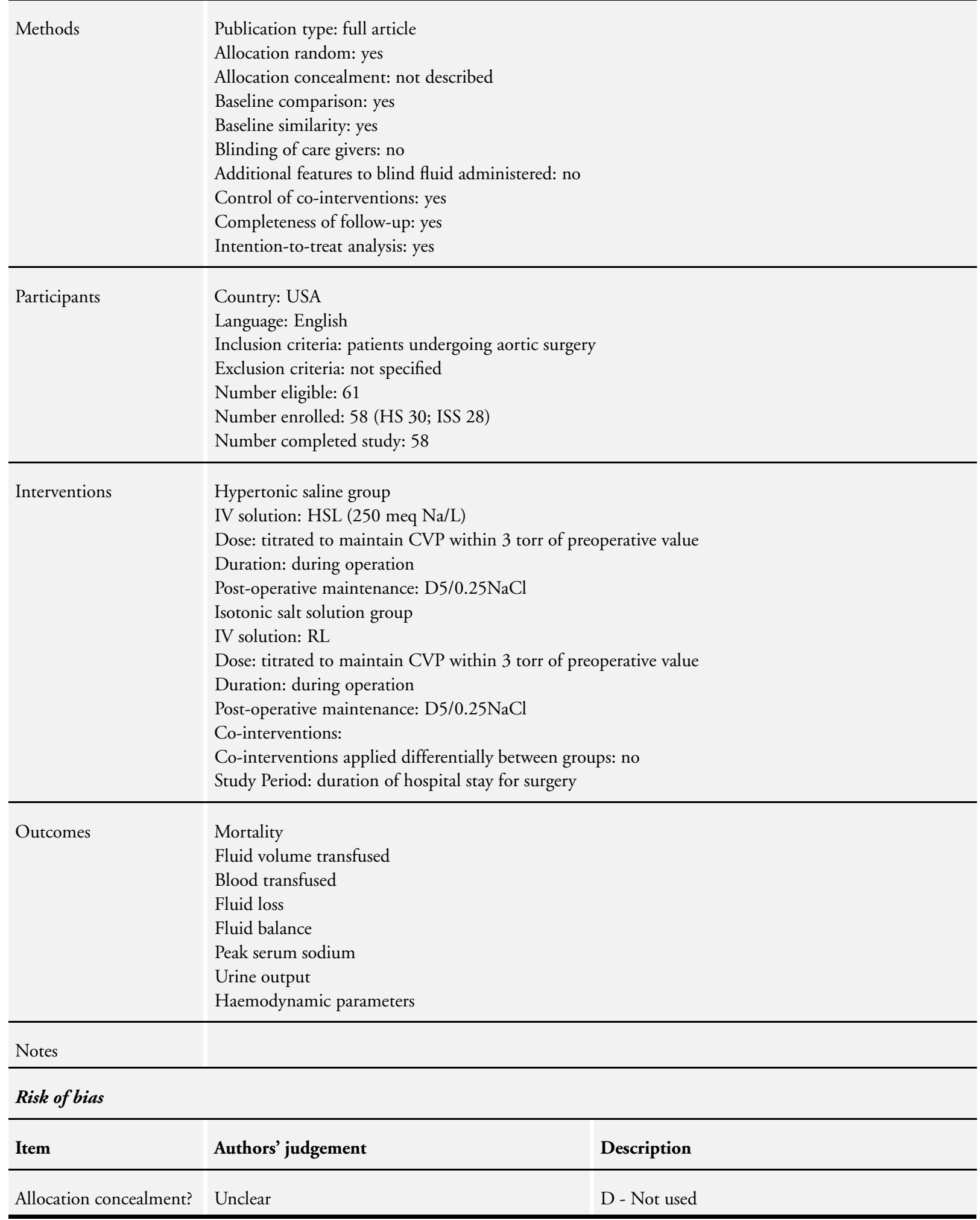

Hypertonic saline for peri-operative fluid management (Review)

Copyright (C) 2010 The Cochrane Collaboration. Published by John Wiley \& Sons, Ltd. 


\begin{tabular}{|c|c|c|}
\hline Methods & \multicolumn{2}{|c|}{$\begin{array}{l}\text { Publication type: full article } \\
\text { Allocation random: yes } \\
\text { Allocation concealment: not described } \\
\text { Baseline comparison: yes } \\
\text { Baseline similarity: yes } \\
\text { Blinding of care givers: no } \\
\text { Additional features to blind fluid administered: no } \\
\text { Control of co-interventions: yes } \\
\text { Completeness of follow-up: yes } \\
\text { Intention-to-treat analysis: yes }\end{array}$} \\
\hline Participants & \multicolumn{2}{|c|}{$\begin{array}{l}\text { Country: USA } \\
\text { Language: English } \\
\text { Inclusion criteria: Patients undergoing aortic aneurysm repair or aorto-bifemoral bypass } \\
\text { Exclusion criteria: not specified } \\
\text { Number eligible: } 52 \\
\text { Number enrolled: } 52 \text { (HS 26; ISS 26) } \\
\text { Number completed study: } 52\end{array}$} \\
\hline Interventions & \multicolumn{2}{|c|}{$\begin{array}{l}\text { Hypertonic saline group } \\
\text { IV solution: HSL ( } 250 \text { meq } \mathrm{Na} / \mathrm{L} \text { ) } \\
\text { Dose: titrated to maintain CVP within } 3 \text { torr of preoperative value } \\
\text { Duration: during operation } \\
\text { Post-operative maintenance: } \mathrm{D} 5 / 0.25 \mathrm{NaCl} \\
\text { Isotonic salt solution group } \\
\text { IV solution: RL } \\
\text { Dose: titrated to maintain CVP within } 3 \text { torr of preoperative value } \\
\text { Duration: during operation } \\
\text { Post-operative maintenance: } \mathrm{D} 5 / 0.25 \mathrm{NaCl} \\
\text { Co-interventions: } \\
\text { Co-interventions applied differentially between groups: no } \\
\text { Study Period: duration of surgery plus first four post-operative days }\end{array}$} \\
\hline Outcomes & \multicolumn{2}{|c|}{$\begin{array}{l}\text { Fluid volume transfused } \\
\text { Blood transfused } \\
\text { Fluid loss } \\
\text { Fluid balance } \\
\text { Weight change } \\
\text { Peak serum sodium } \\
\text { Urine output }\end{array}$} \\
\hline \multicolumn{3}{|l|}{ Notes } \\
\hline \multicolumn{3}{|l|}{ Risk of bias } \\
\hline Item & Authors' judgemen & Description \\
\hline Allocation concealment? & Unclear & B - Unclear \\
\hline
\end{tabular}




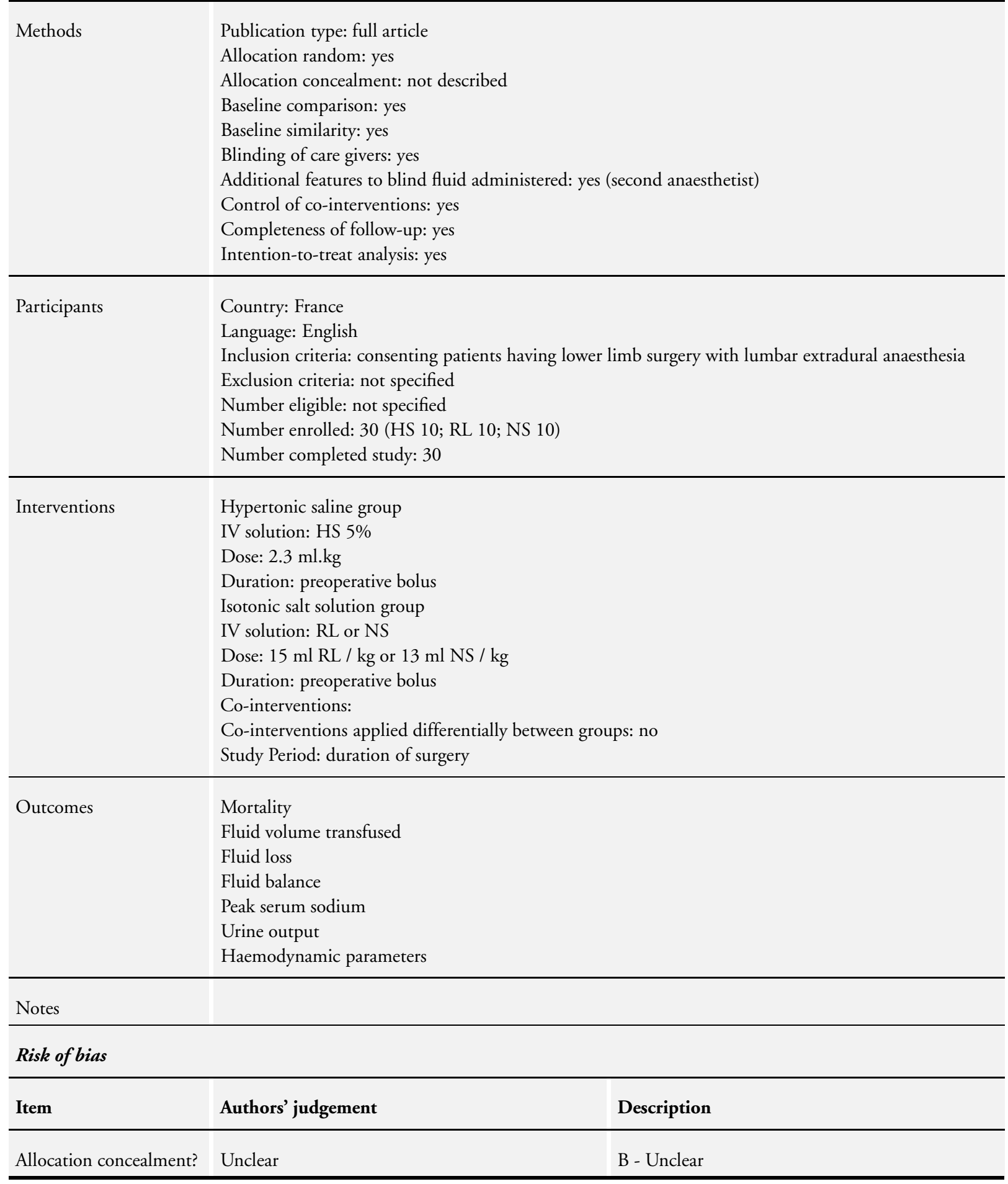




\begin{tabular}{|c|c|}
\hline Methods & $\begin{array}{l}\text { Publication type: full article } \\
\text { Allocation random: unclear } \\
\text { Allocation concealment: not described } \\
\text { Baseline comparison: yes } \\
\text { Baseline similarity: yes } \\
\text { Blinding of care givers: unclear } \\
\text { Additional features to blind fluid administered: no } \\
\text { Control of co-interventions: yes } \\
\text { Completeness of follow-up: yes } \\
\text { Intention-to-treat analysis: yes }\end{array}$ \\
\hline Participants & $\begin{array}{l}\text { Country: China } \\
\text { Language: English } \\
\text { Single centre } \\
\text { Inclusion criteria: consenting fit patients having herniorrhaphy under spinal anaesthesia } \\
\text { Exclusion criteria: ASA II, III or IV } \\
\text { Number eligible: not specified } \\
\text { Number enrolled: } 60 \text { (HS } 30 \text {; ISS 30) } \\
\text { Number completed study: } 60\end{array}$ \\
\hline Interventions & $\begin{array}{l}\text { Hypertonic saline group } \\
\text { IV solution: } 3 \% \mathrm{HS} \\
\text { Dose: } 7 \mathrm{ml} / \mathrm{kg} \\
\text { Duration: bolus before surgery } \\
\text { Isotonic salt solution group } \\
\text { IV solution: } 0.9 \% \mathrm{NaCl} \\
\text { Dose: } 7 \mathrm{ml} / \mathrm{kg} \\
\text { Duration: bolus before surgery } \\
\text { Co-interventions: } \\
\text { Co-interventions applied differentially between groups: no } \\
\text { Study Period: duration of surgery }\end{array}$ \\
\hline Outcomes & $\begin{array}{l}\text { Hypotension } \\
\text { Peak serum sodium } \\
\text { Haemodynamic parameters }\end{array}$ \\
\hline Notes & \\
\hline Risk of bias & \\
\hline Item & Authors' judgement \\
\hline Allocation concealment? & B - Unclear \\
\hline
\end{tabular}


Younes 1988

\begin{tabular}{|c|c|}
\hline Methods & $\begin{array}{l}\text { Publication type: full article } \\
\text { Allocation random: unclear } \\
\text { Allocation concealment: not described } \\
\text { Baseline comparison: yes } \\
\text { Baseline similarity: yes } \\
\text { Blinding of care givers: unclear } \\
\text { Additional features to blind fluid administered: no } \\
\text { Control of co-interventions: yes } \\
\text { Completeness of follow-up: yes } \\
\text { Intention-to-treat analysis: yes }\end{array}$ \\
\hline Participants & $\begin{array}{l}\text { Country: Brazil } \\
\text { Language: Portuguese } \\
\text { Single centre } \\
\text { Inclusion criteria: Adult patients undergoing aortic aneurysm repair or aortobifemoral bypass } \\
\text { Exclusion criteria: not given } \\
\text { Number eligible: not given } \\
\text { Number enrolled: } 31 \text { (HS } 18 \text {; ISS 13) } \\
\text { Number completed study: } 31\end{array}$ \\
\hline Interventions & $\begin{array}{l}\text { Hypertonic saline group } \\
\text { IV solution: } 7.5 \% \mathrm{HS} \\
\text { Dose: } 4 \mathrm{ml} / \mathrm{kg} \\
\text { Duration: } 15 \text { minute bolus } \\
\text { Post-operative maintenance: ISS to maintain CVP and MAP within } 10 \% \text { of starting value } \\
\text { Isotonic salt solution group } \\
\text { IV solution: } 0.9 \% \mathrm{NaCl} \\
\text { Dose: } 4 \mathrm{ml} / \mathrm{kg} \\
\text { Duration: } 15 \text { minute bolus } \\
\text { Post-operative maintenance: ISS to maintain CVP and MAP within } 10 \% \text { of starting value } \\
\text { Co-interventions: } \\
\text { Co-interventions applied differentially between groups: no } \\
\text { Study Period: duration of surgery }\end{array}$ \\
\hline Outcomes & $\begin{array}{l}\text { Mortality } \\
\text { LOS hospital } \\
\text { LOS ICU } \\
\text { Fluid volume transfused } \\
\text { Blood transfused } \\
\text { Fluid loss } \\
\text { Fluid balance } \\
\text { Peak serum sodium } \\
\text { Urine output } \\
\text { Haemodynamic parameters }\end{array}$ \\
\hline Notes & Translation provided by Ms. Christiane Baldwin \\
\hline
\end{tabular}

Risk of bias 
Younes 1988 (Continued)

\begin{tabular}{l|ll}
\hline Item & Authors' judgement & Description \\
\hline Allocation concealment? & Unclear & B - Unclear \\
\hline
\end{tabular}

ASA: American Society Anesthesiology classification

HS: hypertonic saline

HSL: hypertonic saline lactate

NS: normal saline (154 meq Na per litre)

RL: Ringer's Lactate (130 meq Na per litre)

HSL: hypertonic sodium lactate

D $5 / 0.45$ NS: dextrose $5 \%$ in $0.45 \%$ saline

ISS: isotonic salt solution

IV: intravenous

LOS: length of stay

ICU: intensive care unit 
Characteristics of excluded studies [ordered by study ID]

Auler 1987 Consecutive patients enrolled. Study not randomized

Auler 1992 Study of intraoperative respiratory physiology but did not measure outcomes such as weight gain, fluid balance or peak serum sodium or determine postoperative survival.

Shao 2005 Dr Shao kindly responded to an email query on November 30, 2006: "I performed this project non-randomly, allocated distinct groups on the basis of different diseases and operation methods, but single-blinded (for patients)". 
DATA AND ANALYSES

Comparison 3. Fluid balance (L)

\begin{tabular}{|c|c|c|c|c|}
\hline Outcome or subgroup title & $\begin{array}{l}\text { No. of } \\
\text { studies }\end{array}$ & $\begin{array}{c}\text { No. of } \\
\text { participants }\end{array}$ & Statistical method & Effect size \\
\hline $\begin{array}{l}1 \text { Calculated fluid balance } \\
\text { (stratified for surgery type) }\end{array}$ & 5 & 230 & Std. Mean Difference (IV, Random, 95\% CI) & $-1.43[-2.05,-0.80]$ \\
\hline $\begin{array}{l}\text { 1.1 Coronary artery bypass } \\
\text { surgery }\end{array}$ & 2 & 92 & Std. Mean Difference (IV, Random, 95\% CI) & $-1.51[-3.17,0.15]$ \\
\hline 1.2 Aortic surgery & 3 & 138 & Std. Mean Difference (IV, Random, 95\% CI) & $-1.46[-2.21,-0.72]$ \\
\hline $\begin{array}{l}2 \text { Calculated fluid balance } \\
\text { (stratified for dose of HS given) }\end{array}$ & 5 & 230 & Std. Mean Difference (IV, Random, 95\% CI) & $-1.42[-2.05,-0.79]$ \\
\hline $2.1<7.1 \mathrm{~mL} \mathrm{3 \%} \mathrm{HS/kg}$ & 0 & 0 & Std. Mean Difference (IV, Random, 95\% CI) & Not estimable \\
\hline $2.27 .1-10 \mathrm{~mL} 3 \% \mathrm{HS} / \mathrm{kg}$ & 2 & 100 & Std. Mean Difference (IV, Random, 95\% CI) & $-0.82[-1.23,-0.41]$ \\
\hline $2.3>10 \mathrm{~mL} 3 \% \mathrm{HS} / \mathrm{kg}$ & 3 & 130 & Std. Mean Difference (IV, Random, 95\% CI) & $-1.84[-2.72,-0.97]$ \\
\hline $\begin{array}{l}3 \text { Calculated fluid balance } \\
\text { (stratified for volume given in } \\
\text { control group) }\end{array}$ & 5 & 230 & Std. Mean Difference (IV, Random, 95\% CI) & $-1.42[-2.05,-0.79]$ \\
\hline $3.1<2000 \mathrm{~mL}$ & 0 & 0 & Std. Mean Difference (IV, Random, 95\% CI) & Not estimable \\
\hline $3.22000-5000 \mathrm{~mL}$ & 3 & 120 & Std. Mean Difference (IV, Random, 95\% CI) & $-1.24[-2.07,-0.42]$ \\
\hline $3.3>5000 \mathrm{~mL}$ & 2 & 110 & Std. Mean Difference (IV, Random, 95\% CI) & $-1.65[-2.72,-0.57]$ \\
\hline $\begin{array}{l}\text { 4 Calculated fluid balance } \\
\text { (sensitivity analysis by study } \\
\text { quality) }\end{array}$ & 5 & 230 & Std. Mean Difference (IV, Random, 95\% CI) & $-1.45[-2.11,-0.79]$ \\
\hline 4.1 Study grade $=\mathrm{A}$ & 1 & 72 & Std. Mean Difference (IV, Random, 95\% CI) & $-0.75[-1.23,-0.27]$ \\
\hline 4.2 Study group = B & 3 & 100 & Std. Mean Difference (IV, Random, 95\% CI) & $-1.37[-2.07,-0.67]$ \\
\hline 4.3 Study group = D & 1 & 58 & Std. Mean Difference (IV, Random, 95\% CI) & $-2.32[-1.00,-1.65]$ \\
\hline 5 Actual fluid balance (L) & 4 & 158 & Std. Mean Difference (IV, Random, 95\% CI) & $-1.63[-2.32,-0.93]$ \\
\hline
\end{tabular}

Comparison 4. Total volume of crystalloid administered (L)

\begin{tabular}{|c|c|c|c|c|}
\hline Outcome or subgroup title & $\begin{array}{l}\text { No. of } \\
\text { studies }\end{array}$ & $\begin{array}{c}\text { No. of } \\
\text { participants }\end{array}$ & Statistical method & Effect size \\
\hline $\begin{array}{l}1 \text { Volume of crystalloid } \\
\text { administered (stratified for type } \\
\text { of surgery) }\end{array}$ & 10 & 364 & Std. Mean Difference (IV, Random, 95\% CI) & $-2.35[-3.21,-1.49]$ \\
\hline 1.1 Cardiovascular surgery & 6 & 221 & Std. Mean Difference (IV, Random, 95\% CI) & $-1.70[-2.48,-0.93]$ \\
\hline $\begin{array}{l}1.2 \text { Non cardiovascular } \\
\text { surgery }\end{array}$ & 4 & 143 & Std. Mean Difference (IV, Random, 95\% CI) & $-4.04[-6.46,-1.62]$ \\
\hline $\begin{array}{l}2 \text { Volume of crystalloid } \\
\text { administered (stratified by dose } \\
\text { of HS) }\end{array}$ & 10 & 364 & Std. Mean Difference (IV, Random, 95\% CI) & $-2.35[-3.21,-1.49]$ \\
\hline $2.1<7.1 \mathrm{~mL} \mathrm{3 \%} \mathrm{HS/kg}$ & 3 & 103 & Std. Mean Difference (IV, Random, 95\% CI) & $-2.24[-3.93,-0.56]$ \\
\hline $2.27 .1-10 \mathrm{~mL} 3 \% \mathrm{HS} / \mathrm{kg}$ & 4 & 131 & Std. Mean Difference (IV, Random, 95\% CI) & $-3.49[-5.72,-1.26]$ \\
\hline
\end{tabular}




\begin{tabular}{|c|c|c|c|c|}
\hline $2.3>10 \mathrm{~mL} 3 \% \mathrm{HS} / \mathrm{kg}$ & 3 & 130 & Std. Mean Difference (IV, Random, 95\% CI) & $-1.22[-1.98,-0.46]$ \\
\hline $\begin{array}{l}3 \text { Volume of crystalloid } \\
\text { administered (sensitivity } \\
\text { analysis by study quality) }\end{array}$ & 10 & 364 & Std. Mean Difference (IV, Random, 95\% CI) & $-1.70[-2.29,-1.12]$ \\
\hline 3.1 Study grade $=\mathrm{A}$ & 2 & 72 & Std. Mean Difference (IV, Random, 95\% CI) & $-2.83[-5.40,-0.26]$ \\
\hline 3.2 Study group $=\mathrm{B}$ & 7 & 234 & Std. Mean Difference (IV, Random, 95\% CI) & $-1.51[-2.17,-0.86]$ \\
\hline 3.3 Study grade $=\mathrm{D}$ & 1 & 58 & Std. Mean Difference (IV, Random, 95\% CI) & $-1.03[-1.58,-0.48]$ \\
\hline
\end{tabular}

\section{Comparison 5. Diuresis during study period $(\mathrm{L})$}

\begin{tabular}{|c|c|c|c|c|}
\hline Outcome or subgroup title & $\begin{array}{l}\text { No. of } \\
\text { studies }\end{array}$ & $\begin{array}{c}\text { No. of } \\
\text { participants }\end{array}$ & Statistical method & Effect size \\
\hline 1 Diuresis during study period (L) & 6 & 270 & Std. Mean Difference (IV, Random, 95\% CI) & $0.20[-0.19,0.58]$ \\
\hline $\begin{array}{l}2 \text { Diuresis during study period } \\
\text { (stratified by dose of HS) }\end{array}$ & 6 & 270 & Std. Mean Difference (IV, Random, 95\% CI) & $0.17[-0.23,0.57]$ \\
\hline $2.1<7.1 \mathrm{~mL} \mathrm{3 \%} \mathrm{HS/kg}$ & 0 & 0 & Std. Mean Difference (IV, Random, 95\% CI) & Not estimable \\
\hline $2.27 .1-10 \mathrm{~mL} 3 \% \mathrm{HS} / \mathrm{kg}$ & 3 & 140 & Std. Mean Difference (IV, Random, 95\% CI) & $0.15[-0.25,0.55]$ \\
\hline $2.3>10 \mathrm{~mL} 3 \% \mathrm{HS} / \mathrm{kg}$ & 3 & 130 & Std. Mean Difference (IV, Random, 95\% CI) & $0.33[-0.51,1.17]$ \\
\hline $\begin{array}{l}3 \text { Diuresis during study period } \\
\text { (stratified for type of surgery) }\end{array}$ & 6 & 270 & Std. Mean Difference (IV, Random, 95\% CI) & $0.20[-0.20,0.61]$ \\
\hline 3.1 Cardiovascular surgery & 5 & 230 & Std. Mean Difference (IV, Random, 95\% CI) & $0.21[-0.29,0.70]$ \\
\hline $\begin{array}{l}3.2 \text { Non cardiovascular } \\
\text { surgery }\end{array}$ & 1 & 40 & Std. Mean Difference (IV, Random, 95\% CI) & $0.25[-0.37,0.87]$ \\
\hline $\begin{array}{l}4 \text { Diuresis during study period } \\
\text { (stratified for volume of } \\
\text { crystalloid infused) }\end{array}$ & 6 & 270 & Std. Mean Difference (IV, Random, 95\% CI) & $0.17[-0.23,0.57]$ \\
\hline $4.1<2000 \mathrm{~mL}$ & 2 & 68 & Std. Mean Difference (IV, Random, 95\% CI) & $-0.07[-0.55,0.40]$ \\
\hline $4.22000-5000 \mathrm{~mL}$ & 2 & 92 & Std. Mean Difference (IV, Random, 95\% CI) & $0.94[-0.25,2.12]$ \\
\hline $4.3>5000 \mathrm{~mL}$ & 2 & 110 & Std. Mean Difference (IV, Random, 95\% CI) & $-0.13[-0.50,0.25]$ \\
\hline $\begin{array}{l}5 \text { Diuresis during study period } \\
\text { (sensitivity analysis by study } \\
\text { quality) }\end{array}$ & 6 & 270 & Std. Mean Difference (IV, Random, 95\% CI) & $0.17[-0.23,0.57]$ \\
\hline 5.1 Study grade $=\mathrm{A}$ & 2 & 112 & Std. Mean Difference (IV, Random, 95\% CI) & $0.29[-0.08,0.66]$ \\
\hline 5.2 Study grade $=$ B & 3 & 100 & Std. Mean Difference (IV, Random, 95\% CI) & $0.33[-0.64,1.30]$ \\
\hline 5.3 Study grade $=\mathrm{D}$ & 1 & 58 & Std. Mean Difference (IV, Random, 95\% CI) & $-0.16[-0.67,0.36]$ \\
\hline
\end{tabular}

Comparison 6. Peak serum sodium (meq/L)

\begin{tabular}{lcccc} 
Outcome or subgroup title & $\begin{array}{c}\text { No. of } \\
\text { studies }\end{array}$ & $\begin{array}{c}\text { No. of } \\
\text { participants }\end{array}$ & Statistical method & Effect size \\
\hline $\begin{array}{l}\text { 1 Peak serum sodium (stratified by } \\
\text { type of surgery) }\end{array}$ & 14 & 532 & Std. Mean Difference (IV, Random, 95\% CI) & $2.24[1.59,2.89]$ \\
$\begin{array}{l}1.1 \text { Cardiovascular surgery } \\
1.2 \text { Transurethral resection of }\end{array}$ & 6 & 261 & $\begin{array}{l}\text { Std. Mean Difference (IV, Random, 95\% CI) } \\
\text { Std. Mean Difference (IV, Random, 95\% CI) }\end{array}$ & $1.17[0.20[1.98,4.42]$ \\
the prostate & 87 & & & \\
\hline $\begin{array}{l}\text { Hypertonic saline for peri-operative fluid management (Review) } \\
\text { Copyright } \odot \text { 2010 The Cochrane Collaboration. Published by John Wiley \& Sons, Ltd. }\end{array}$
\end{tabular}


1.3 Other surgery

2 Peak serum sodium (stratified by dose of HS)

$2.1<7.1 \mathrm{~mL} 3 \% \mathrm{HS} / \mathrm{kg}$ $2.27 .1-10 \mathrm{~mL} 3 \% \mathrm{HS} / \mathrm{kg}$ $2.3>10 \mathrm{~mL} \mathrm{3 \%} \mathrm{HS/kg}$

3 Peak serum sodium (stratified by volume given in control group)

$3.1<2000 \mathrm{~mL} / \mathrm{kg}$ $3.22000-5000 \mathrm{~mL}$ $3.3>5000 \mathrm{~mL}$

4 Peak serum sodium (sensitivity analysis by study quality)

4.1 Study grade $=\mathrm{A}$

4.2 Study grade $=$ B

4.3 Study grade $=$ D

$\begin{array}{cc}5 & 184 \\ 14 & 532 \\ & \\ 5 & 178 \\ 5 & 210 \\ 4 & 144 \\ 9 & 371 \\ & \\ 4 & 141 \\ 3 & 120 \\ 2 & 110 \\ 14 & 532 \\ & \\ 2 & 112 \\ 11 & 362 \\ 1 & 58\end{array}$

Std. Mean Difference (IV, Random, 95\% CI)

$1.89[0.97,2.81]$

Std. Mean Difference (IV, Random, 95\% CI)

$2.24[1.59,2.89]$

Std. Mean Difference (IV, Random, 95\% CI)

$1.11[0.54,1.68]$

Std. Mean Difference (IV, Random, 95\% CI)

$3.26[1.96,4.57]$

Std. Mean Difference (IV, Random, 95\% CI)

$2.43[1.44,3.41]$

Std. Mean Difference (IV, Random, 95\% CI)

$2.69[1.89,3.48]$

Std. Mean Difference (IV, Random, 95\% CI)

$1.76[1.22,2.31]$

Std. Mean Difference (IV, Random, 95\% CI)

$5.06[3.28,6.84]$

Std. Mean Difference (IV, Random, 95\% CI)

$1.91[1.16,2.67]$

Mean Difference (IV, Random, 95\% CI)

$7.64[5.47,9.80]$

Mean Difference (IV, Random, 95\% CI)

$7.50[2.60,12.40]$

Mean Difference (IV, Random, 95\% CI)

$7.33[4.59,10.08]$ $12.0[8.09,15.91]$

Comparison 7. Final serum sodium (meq/L)

\begin{tabular}{|c|c|c|c|c|}
\hline Outcome or subgroup title & $\begin{array}{l}\text { No. of } \\
\text { studies }\end{array}$ & $\begin{array}{c}\text { No. of } \\
\text { participants }\end{array}$ & Statistical method & Effect size \\
\hline 1 Final serum sodium (all studies) & 10 & 392 & Std. Mean Difference (IV, Random, 95\% CI) & $1.07[0.60,1.54]$ \\
\hline $\begin{array}{l}2 \text { Final serum sodium (stratified } \\
\text { by dose of HS given) }\end{array}$ & 10 & 392 & Std. Mean Difference (IV, Random, 95\% CI) & $1.07[0.60,1.54]$ \\
\hline $2.1<7.1 \mathrm{~mL} \mathrm{3 \%} \mathrm{HS/kg}$ & 2 & 100 & Std. Mean Difference (IV, Random, 95\% CI) & $0.89[0.47,1.30]$ \\
\hline $2.27 .1-10 \mathrm{~mL} 3 \% \mathrm{HS} / \mathrm{kg}$ & 5 & 162 & Std. Mean Difference (IV, Random, 95\% CI) & $1.07[0.06,2.07]$ \\
\hline $2.3>10 \mathrm{~mL} 3 \% \mathrm{HS} / \mathrm{kg}$ & 3 & 130 & Std. Mean Difference (IV, Random, 95\% CI) & $1.21[0.43,2.00]$ \\
\hline $\begin{array}{l}3 \text { Final serum sodium (stratified by } \\
\text { volume given in control group) }\end{array}$ & 8 & 293 & Std. Mean Difference (IV, Random, 95\% CI) & $1.17[0.55,1.79]$ \\
\hline $3.1<2000 \mathrm{~mL}$ & 3 & 111 & Std. Mean Difference (IV, Random, 95\% CI) & $0.96[-0.49,2.42]$ \\
\hline $3.22000-5000 \mathrm{~mL}$ & 3 & 72 & Std. Mean Difference (IV, Random, 95\% CI) & $1.73[0.68,2.78]$ \\
\hline $3.3>5000 \mathrm{~mL}$ & 2 & 110 & Std. Mean Difference (IV, Random, 95\% CI) & $0.83[0.43,1.22]$ \\
\hline $\begin{array}{l}4 \text { Final serum sodium (stratified } \\
\text { by type of surgery) }\end{array}$ & 10 & 392 & Std. Mean Difference (IV, Random, 95\% CI) & $1.07[0.60,1.54]$ \\
\hline 4.1 Cardiovascular surgery & 5 & 182 & Std. Mean Difference (IV, Random, 95\% CI) & $1.28[0.65,1.91]$ \\
\hline $\begin{array}{l}4.2 \text { Transurethral resection of } \\
\text { prostate }\end{array}$ & 1 & 40 & Std. Mean Difference (IV, Random, 95\% CI) & $0.78[0.14,1.43]$ \\
\hline 4.3 Other surgery & 4 & 170 & Std. Mean Difference (IV, Random, 95\% CI) & $0.91[-0.04,1.87]$ \\
\hline $\begin{array}{l}5 \text { Final serum sodium (sensitivity } \\
\text { analysis by study quality) }\end{array}$ & 10 & 392 & Mean Difference (IV, Random, 95\% CI) & $3.18[1.91,4.44]$ \\
\hline 5.1 Study grade $=\mathrm{A}$ & 2 & 80 & Mean Difference (IV, Random, 95\% CI) & $3.45[0.51,6.39]$ \\
\hline 5.2 Study grade $=$ B & 7 & 254 & Mean Difference (IV, Random, 95\% CI) & $2.74[1.11,4.38]$ \\
\hline 5.3 Study grade $=\mathrm{D}$ & 1 & 58 & Mean Difference (IV, Random, 95\% CI) & $10.0[3.75,16.25]$ \\
\hline
\end{tabular}

Hypertonic saline for peri-operative fluid management (Review) 


\begin{tabular}{lcccc} 
Outcome or subgroup title & $\begin{array}{c}\text { No. of } \\
\text { studies }\end{array}$ & $\begin{array}{c}\text { No. of } \\
\text { participants }\end{array}$ & Statistical method & Effect size \\
\hline $\begin{array}{l}1 \text { Maximum intraoperative serum } \\
\text { osmolarity (mOsm/kg H2O) }\end{array}$ & 9 & 329 & Std. Mean Difference (IV, Random, 95\% CI) & $2.72[1.73,3.71]$ \\
$\begin{array}{c}2 \text { Maximum intraoperative } \\
\text { pulmonary artery wedge } \\
\text { pressure (mm Hg) }\end{array}$ & 3 & 150 & Std. Mean Difference (IV, Random, 95\% CI) & $-0.00[-0.33,0.32]$ \\
$\begin{array}{l}3 \text { Maximum intraoperative cardiac } \\
\text { index (L/min/M2) }\end{array}$ & 5 & 210 & Std. Mean Difference (IV, Random, 95\% CI) & $0.55[0.10,1.00]$ \\
\hline
\end{tabular}

\section{Analysis 3.I. Comparison 3 Fluid balance (L), Outcome I Calculated fluid balance (stratified for surgery type).}

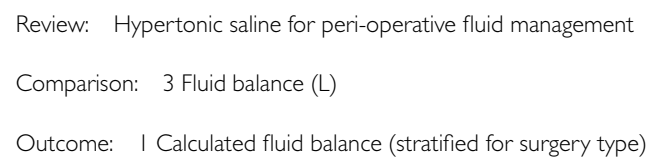

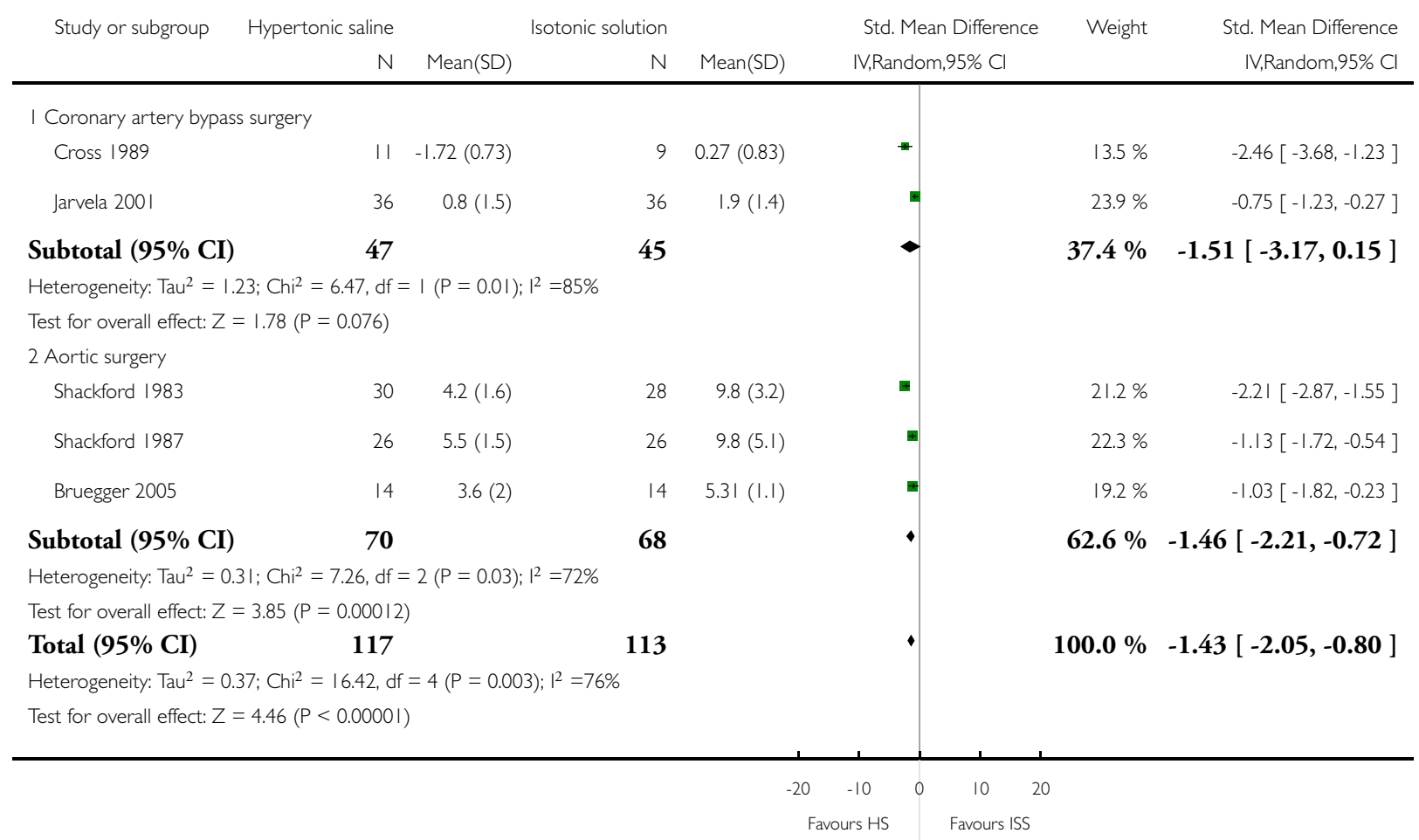


Analysis 3.2. Comparison 3 Fluid balance (L), Outcome 2 Calculated fluid balance (stratified for dose of HS given).

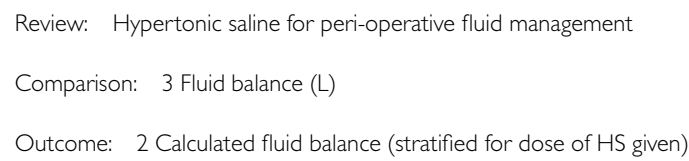

I $<7.1 \mathrm{~mL} 3 \% \mathrm{HS} / \mathrm{kg}$

Subtotal (95\% CI)

Heterogeneity: not applicable

Test for overall effect: not applicable

27.1 - $10 \mathrm{~mL} 3 \% \mathrm{HS} / \mathrm{kg}$

Bruegger 2005

Jarvela 2001

Subtotal (95\% CI)

Heterogeneity: $\operatorname{Tau}^{2}=0.0 ; \mathrm{Chi}^{2}=0.32, \mathrm{df}=\mathrm{I}(\mathrm{P}=0.57) ; \mathrm{I}^{2}=0.0 \%$

Test for overall effect: $Z=3.92(P=0.000087)$

$3>10 \mathrm{~mL} 3 \% \mathrm{HS} / \mathrm{kg}$

Cross 1989

II - $1.72(0.73)$

Shackford 1983

Shackford 1987

Subtotal (95\% CI)

$30 \quad 4.2(1.6)$

$26 \quad 5.5(1.5)$

67

Heterogeneity: $\mathrm{Tau}^{2}=0.43 ; \mathrm{Chi}^{2}=7.65, \mathrm{df}=2(\mathrm{P}=0.02) ; \mathrm{I}^{2}=74 \%$

Test for overall effect: $Z=4.13(P=0.000037)$

Total (95\% CI)

117

Heterogeneity: $\operatorname{Tau}^{2}=0.37 ; \mathrm{Chi}^{2}=16.5 \mathrm{I}, \mathrm{df}=4(\mathrm{P}=0.002) ; \mathrm{I}^{2}=76 \%$

Test for overall effect: $Z=4.43(P<0.0000 \mathrm{I})$

\section{$\mathbf{0}$}

(n)

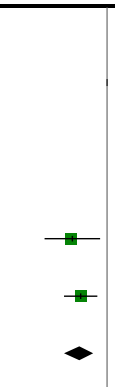

50

$4 \quad 5.31(1.08)$

$36 \quad 1.9(1.4)$

$<$

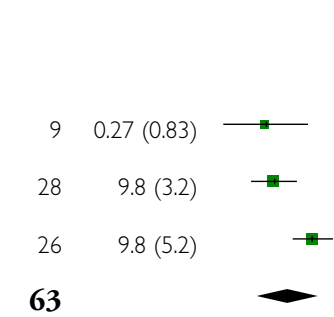

63

113
$0.0 \%$

$0.0[0.0,0.0]$

$19.2 \%$

$-1.02[-1.81,-0.22]$

$23.8 \%$

$-0.75[-1.23,-0.27]$

$43.0 \%-0.82[-1.23,-0.41]$

$\begin{array}{ll}13.5 \% & -2.46[-3.68,-1.23] \\ 21.2 \% & -2.21[-2.87,-1.55] \\ 22.3 \% & -1.11[-1.69,-0.52]\end{array}$

$57.0 \%-1.84[-2.72,-0.97]$

$100.0 \%-1.42[-2.05,-0.79]$ 
Analysis 3.3. Comparison 3 Fluid balance (L), Outcome 3 Calculated fluid balance (stratified for volume given in control group).

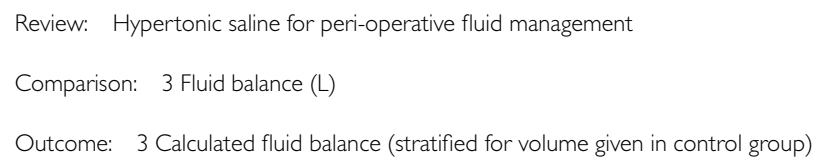

$\mathbf{0}$

Heterogeneity: not applicable

Test for overall effect: not applicable

22000 - $5000 \mathrm{~mL}$

Bruegger 2005

Cross 1989

Jarvela 200 I

Subtotal (95\% CI)

Heterogeneity: $\mathrm{Tau}^{2}=0.35 ; \mathrm{Ch}^{2}=6.48, \mathrm{df}=2(\mathrm{P}=0.04) ; \mathrm{I}^{2}=69 \%$

Test for overall effect: $Z=2.97(P=0.0030)$

$3>5000 \mathrm{~mL}$

Shackford 1983

Shackford 1987

Subtotal (95\% CI)

Heterogeneity: $\mathrm{Tau}^{2}=0.50 ; \mathrm{Chi}^{2}=5.95, \mathrm{df}=\mathrm{I}(\mathrm{P}=0.0 \mathrm{I}) ; \mathrm{I}^{2}=83 \%$

Test for overall effect: $Z=2.99(P=0.0028)$

Total (95\% CI)

117

$4.2(1.6)$

$5.5(1.5)$

Heterogeneity: $\mathrm{Tau}^{2}=0.37 ; \mathrm{Chi}^{2}=16.5 \mathrm{I}, \mathrm{df}=4(\mathrm{P}=0.002) ; \mathrm{I}^{2}=76 \%$

Test for overall effect: $Z=4.43(P<0.0000 \mathrm{I})$

\section{0}

(n)

$0.0 \%$

$0.0[0.0,0.0]$

14

$5.31(1.08)$

$0.27(0.83) \longleftarrow$

36

$1.9(1.4)$

59

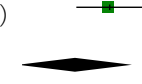

$19.2 \%-1.02[-1.81,-0.22]$

$13.5 \% \quad-2.46[-3.68,-1.23]$

$23.8 \% \quad-0.75[-1.23,-0.27]$

$56.5 \%-1.24[-2.07,-0.42]$

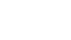
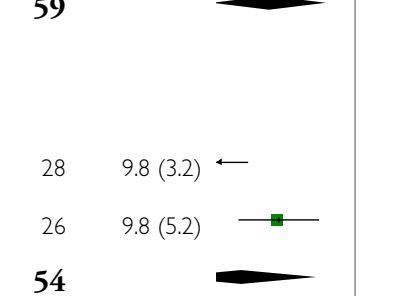

$\begin{array}{rr}22.3 \% & -1.11[-1.69,-0.52] \\ \mathbf{3 . 5} \% & \mathbf{- 1 . 6 5}[\mathbf{- 2 . 7 2}, \mathbf{- 0 . 5 7}]\end{array}$

$100.0 \%-1.42[-2.05,-0.79]$
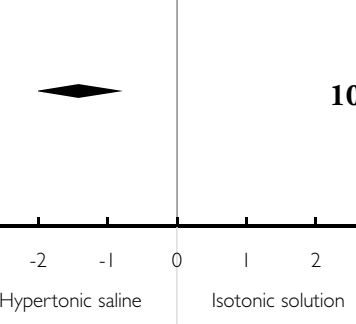


\section{Analysis 3.4. Comparison 3 Fluid balance (L), Outcome 4 Calculated fluid balance (sensitivity analysis by study quality).}

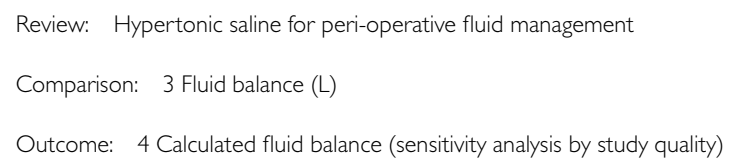

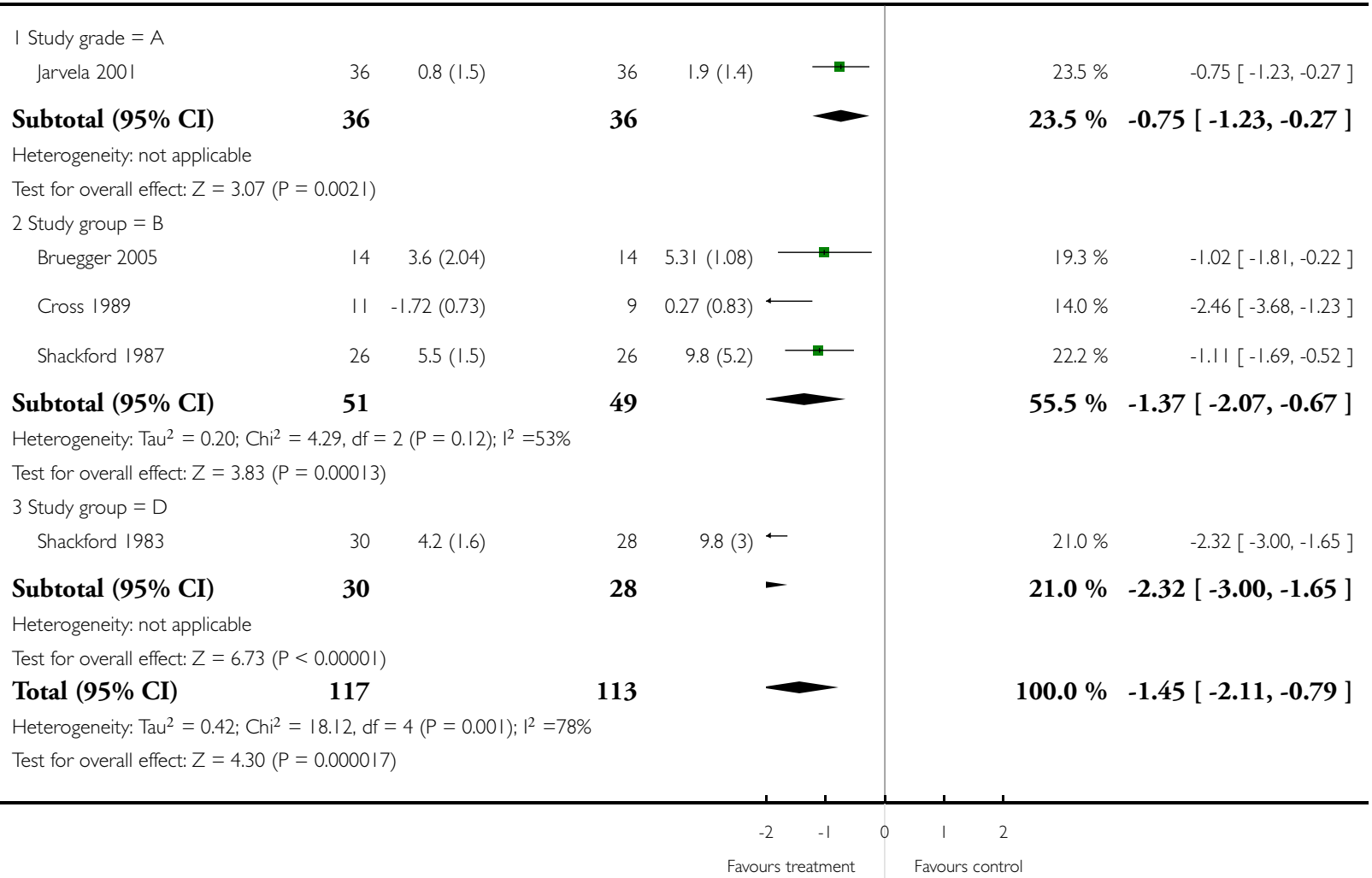




\section{Analysis 3.5. Comparison 3 Fluid balance (L), Outcome 5 Actual fluid balance (L).}

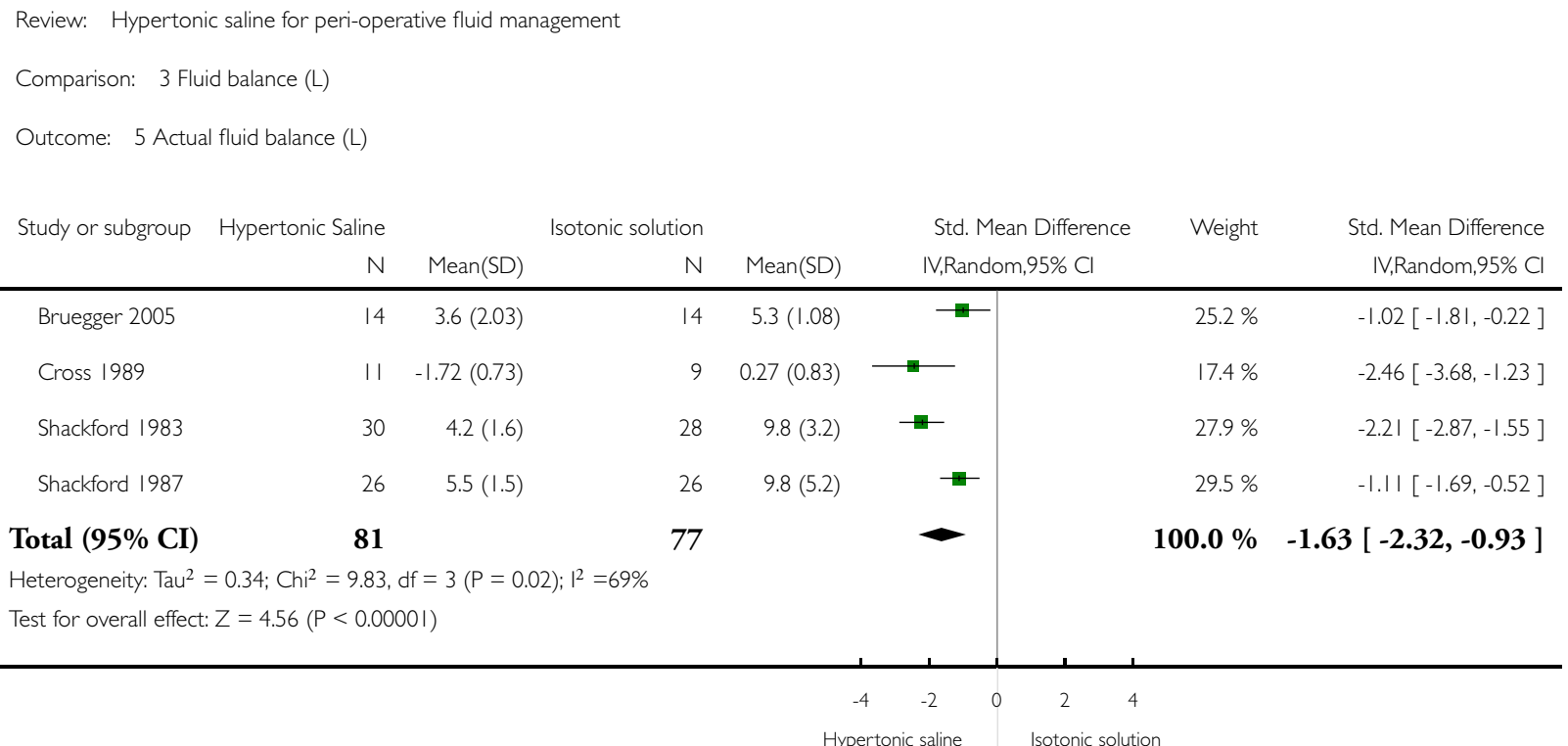

Analysis 4.I. Comparison 4 Total volume of crystalloid administered (L), Outcome I Volume of crystalloid administered (stratified for type of surgery).

Review: Hypertonic saline for peri-operative fluid management

Comparison: 4 Total volume of crystalloid administered $(\mathrm{L})$

Outcome: I Volume of crystalloid administered (stratified for type of surgery)

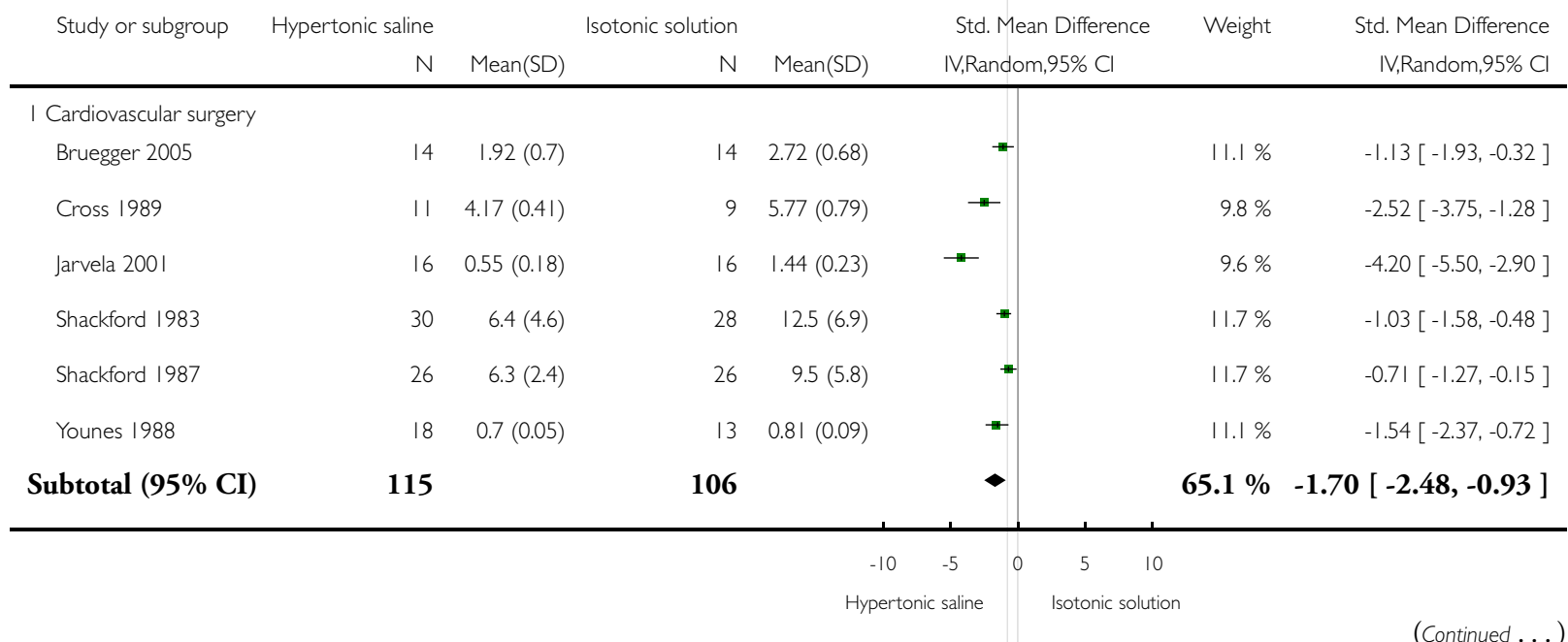




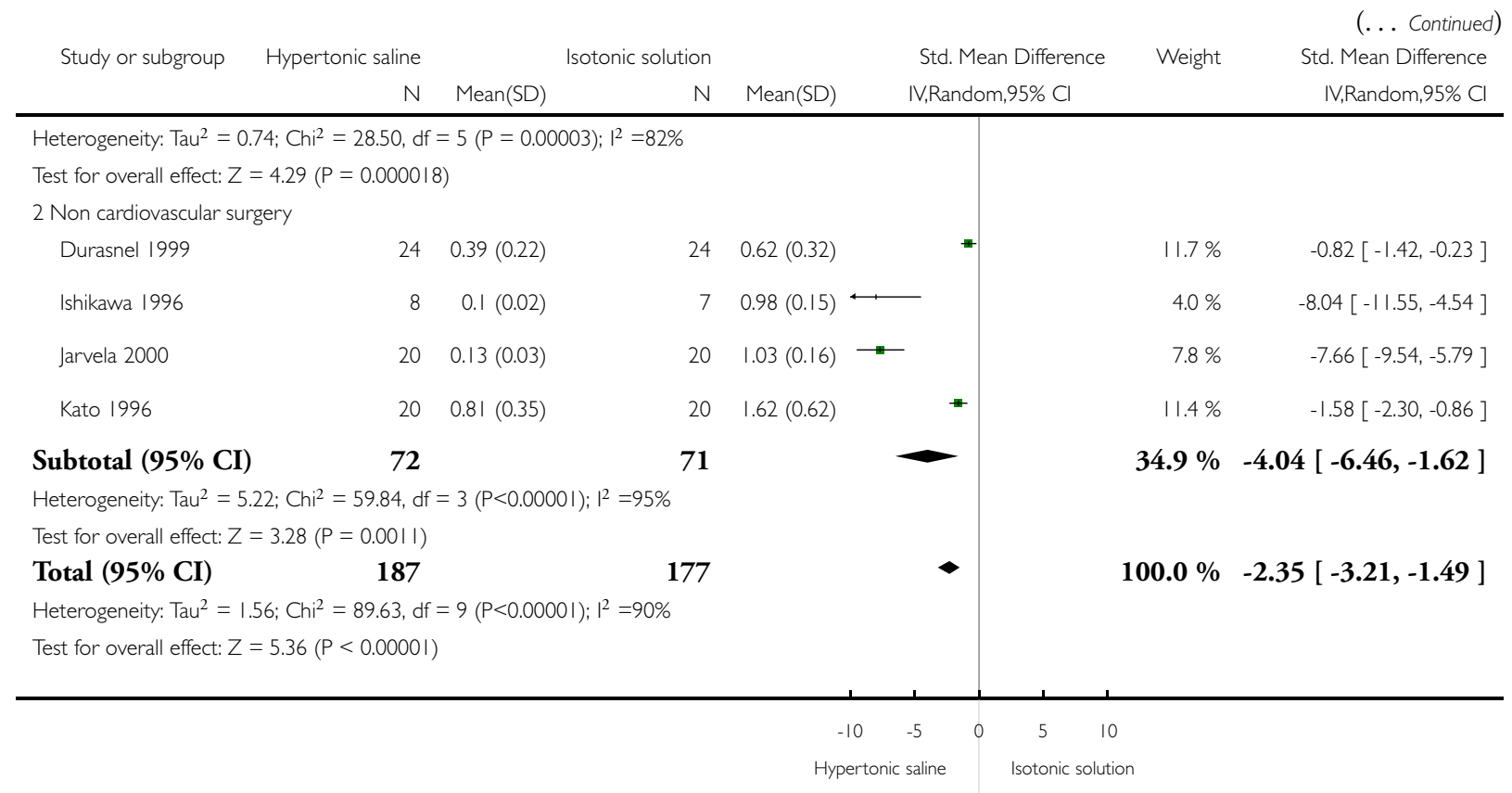

\section{Analysis 4.2. Comparison 4 Total volume of crystalloid administered (L), Outcome 2 Volume of crystalloid administered (stratified by dose of HS).}

Review: Hypertonic saline for peri-operative fluid management

Comparison: 4 Total volume of crystalloid administered $(\mathrm{L})$

Outcome: 2 Volume of crystalloid administered (stratified by dose of HS)

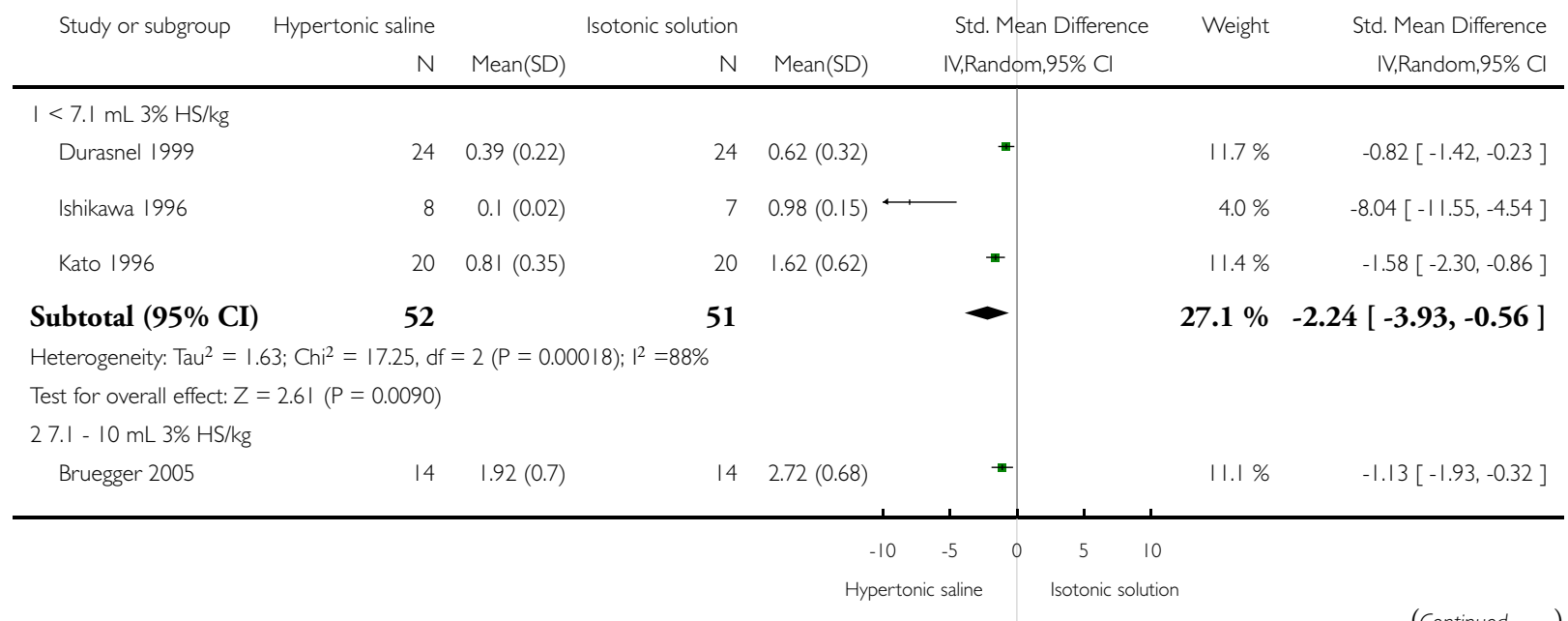




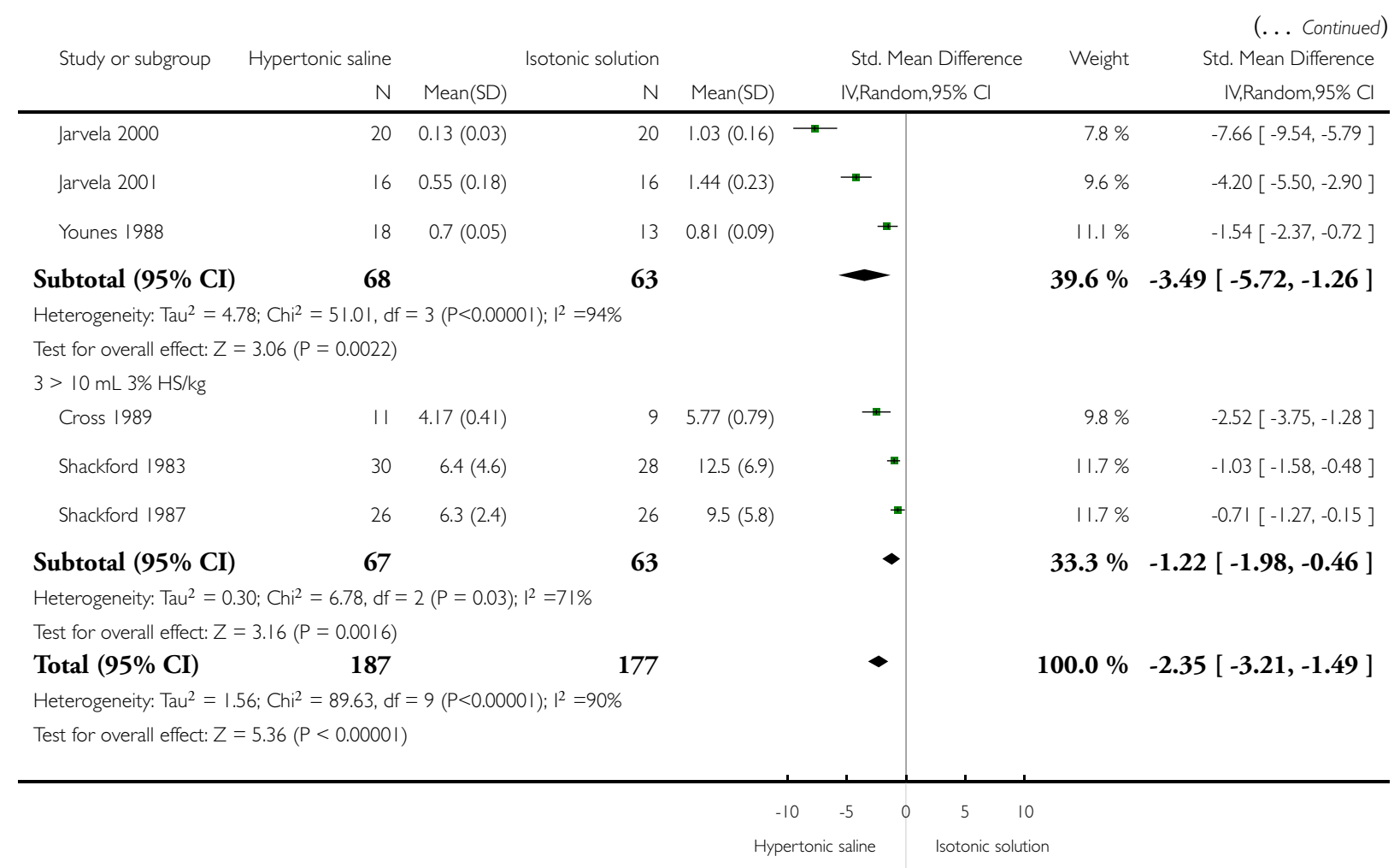




\section{Analysis 4.3. Comparison 4 Total volume of crystalloid administered (L), Outcome 3 Volume of crystalloid administered (sensitivity analysis by study quality).}

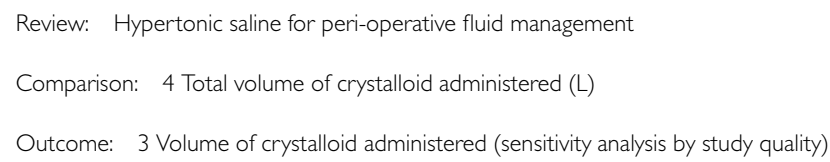

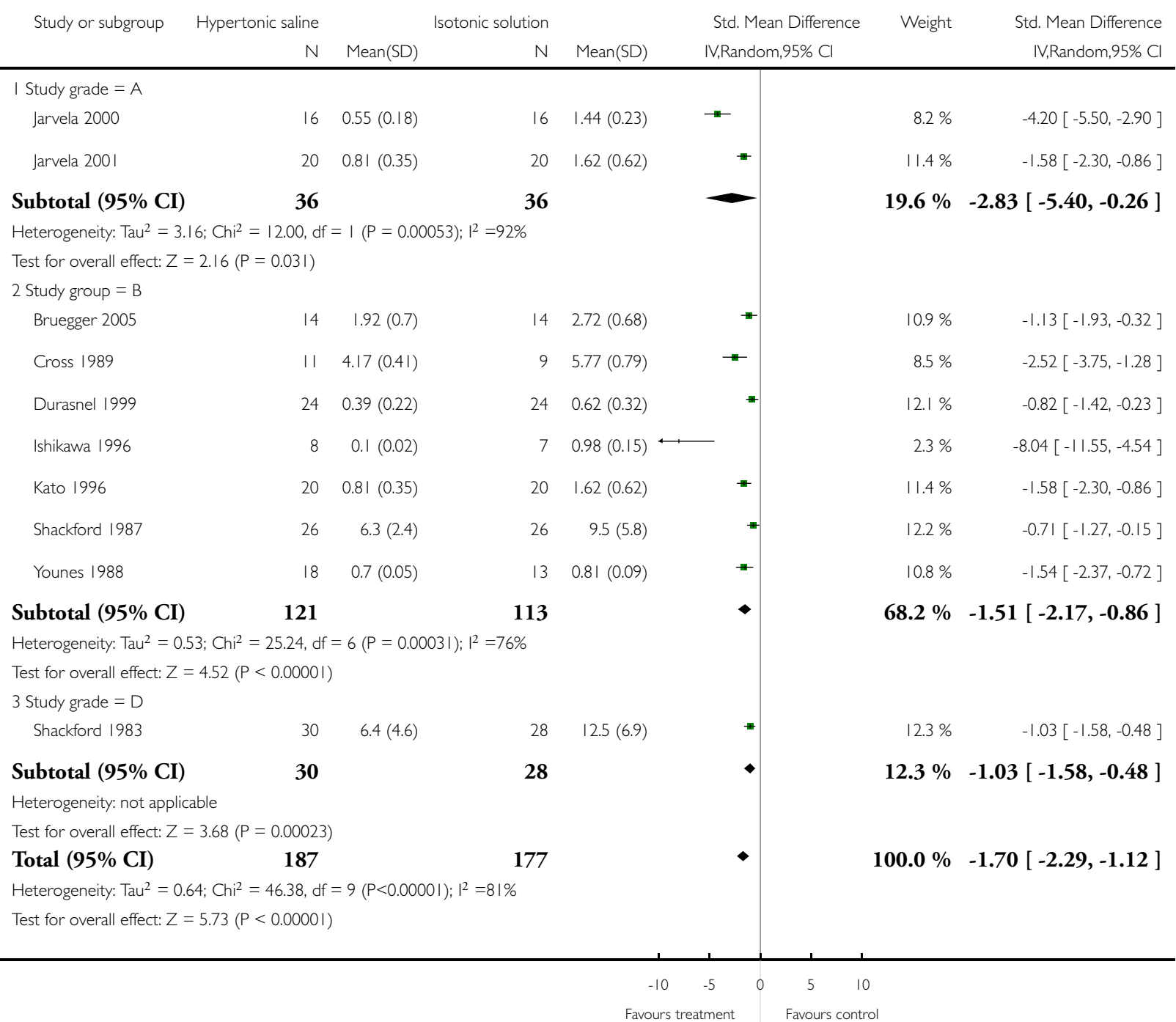


Analysis 5.I. Comparison 5 Diuresis during study period (L), Outcome I Diuresis during study period (L).

Review: Hypertonic saline for peri-operative fluid management

Comparison: 5 Diuresis during study period $(\mathrm{L})$

Outcome: I Diuresis during study period $(\mathrm{L})$

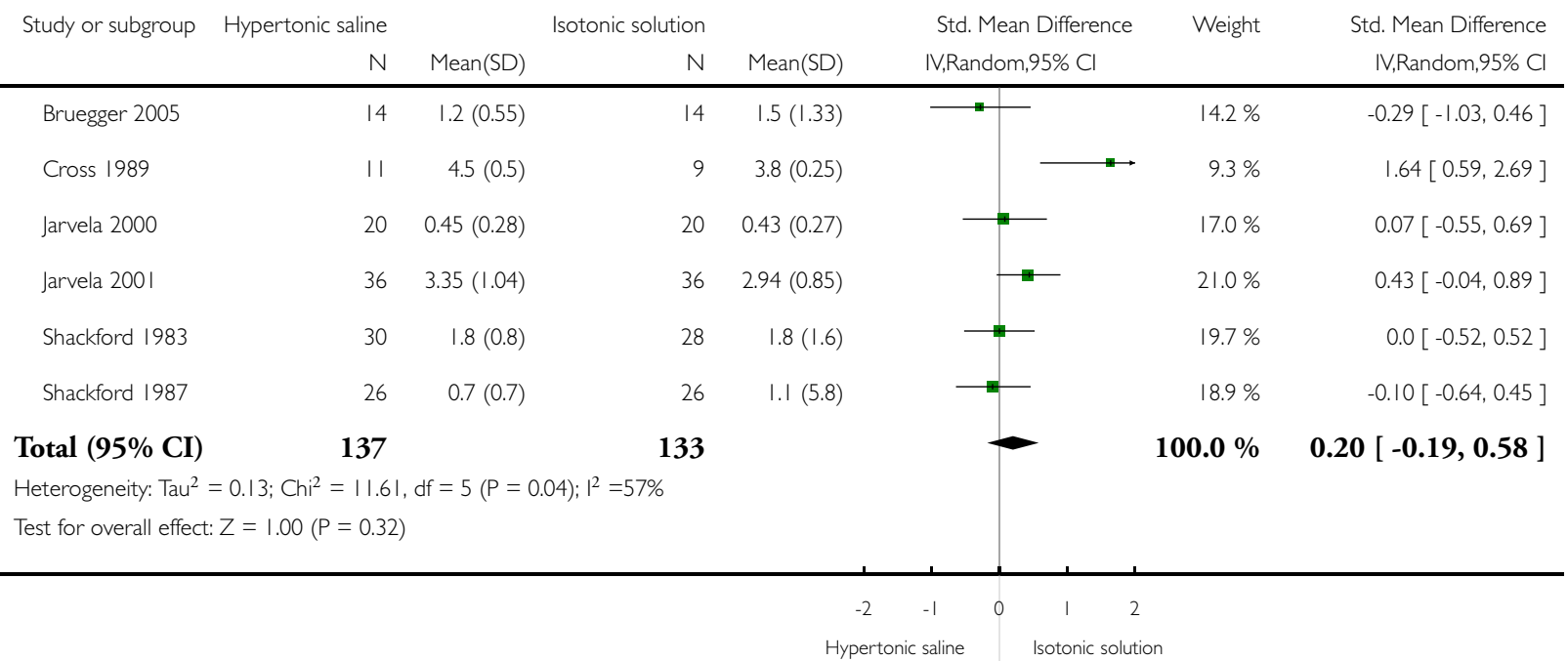


Analysis 5.2. Comparison 5 Diuresis during study period (L), Outcome 2 Diuresis during study period (stratified by dose of HS).

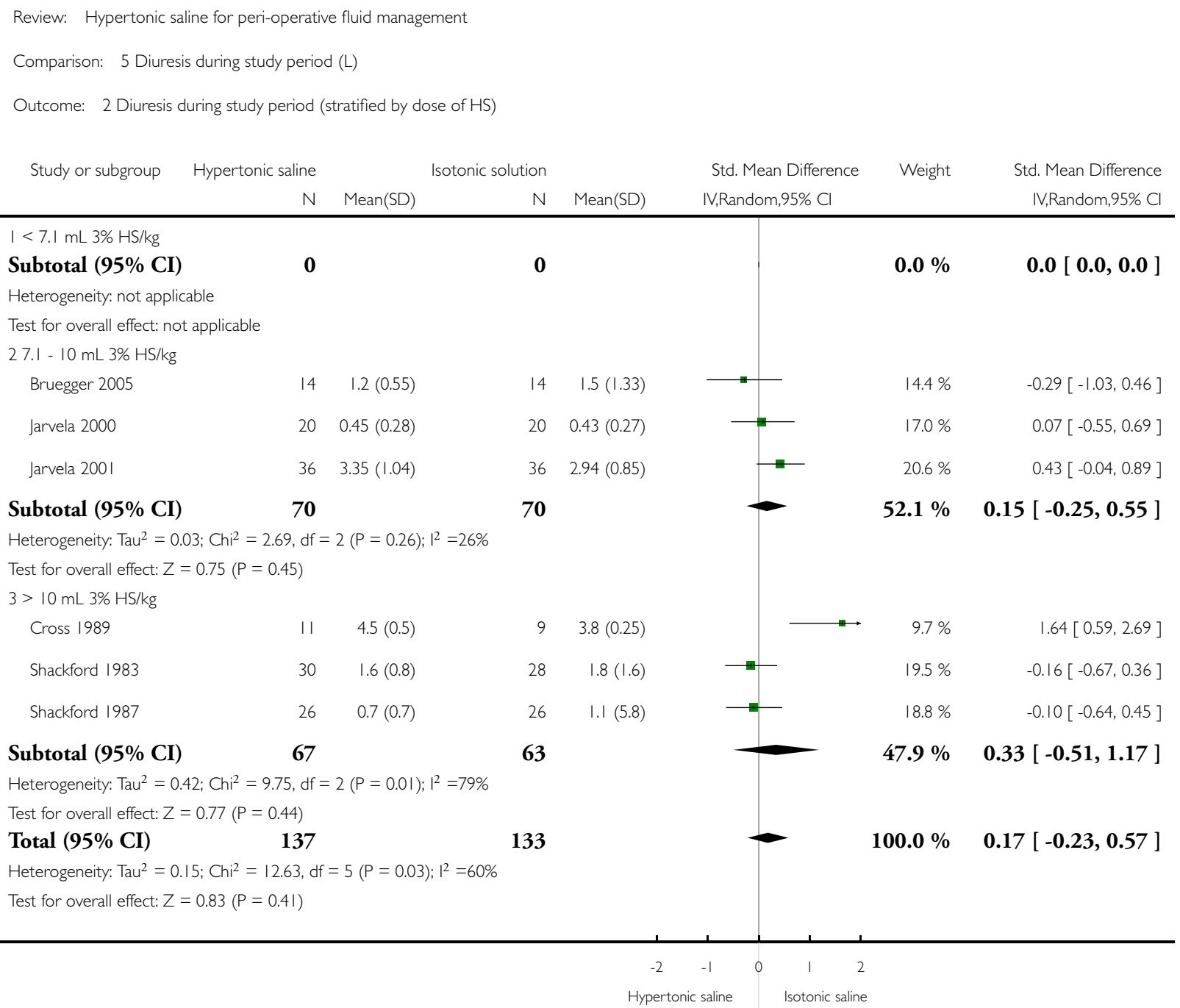


Analysis 5.3. Comparison 5 Diuresis during study period (L), Outcome 3 Diuresis during study period (stratified for type of surgery).

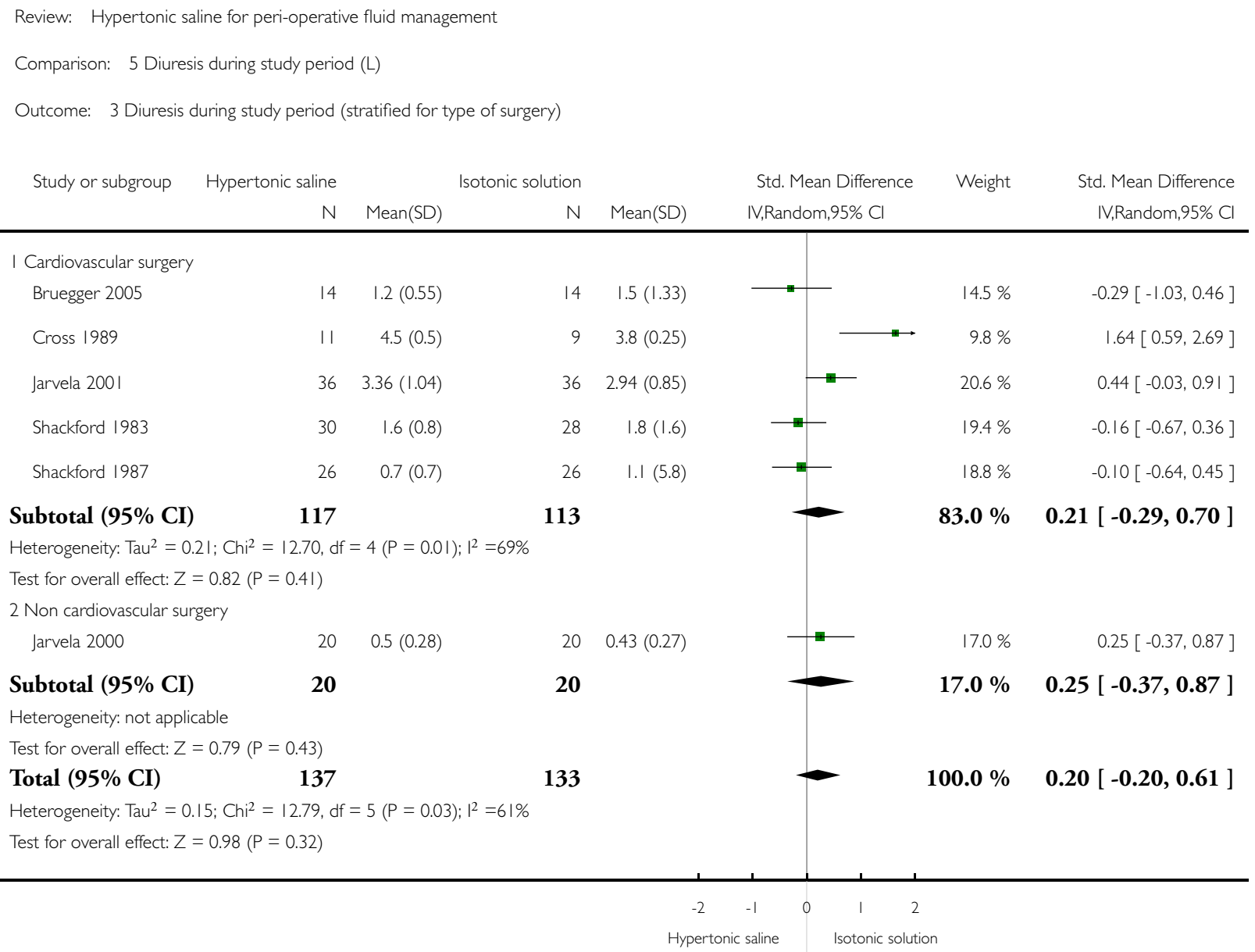


Analysis 5.4. Comparison 5 Diuresis during study period (L), Outcome 4 Diuresis during study period (stratified for volume of crystalloid infused).

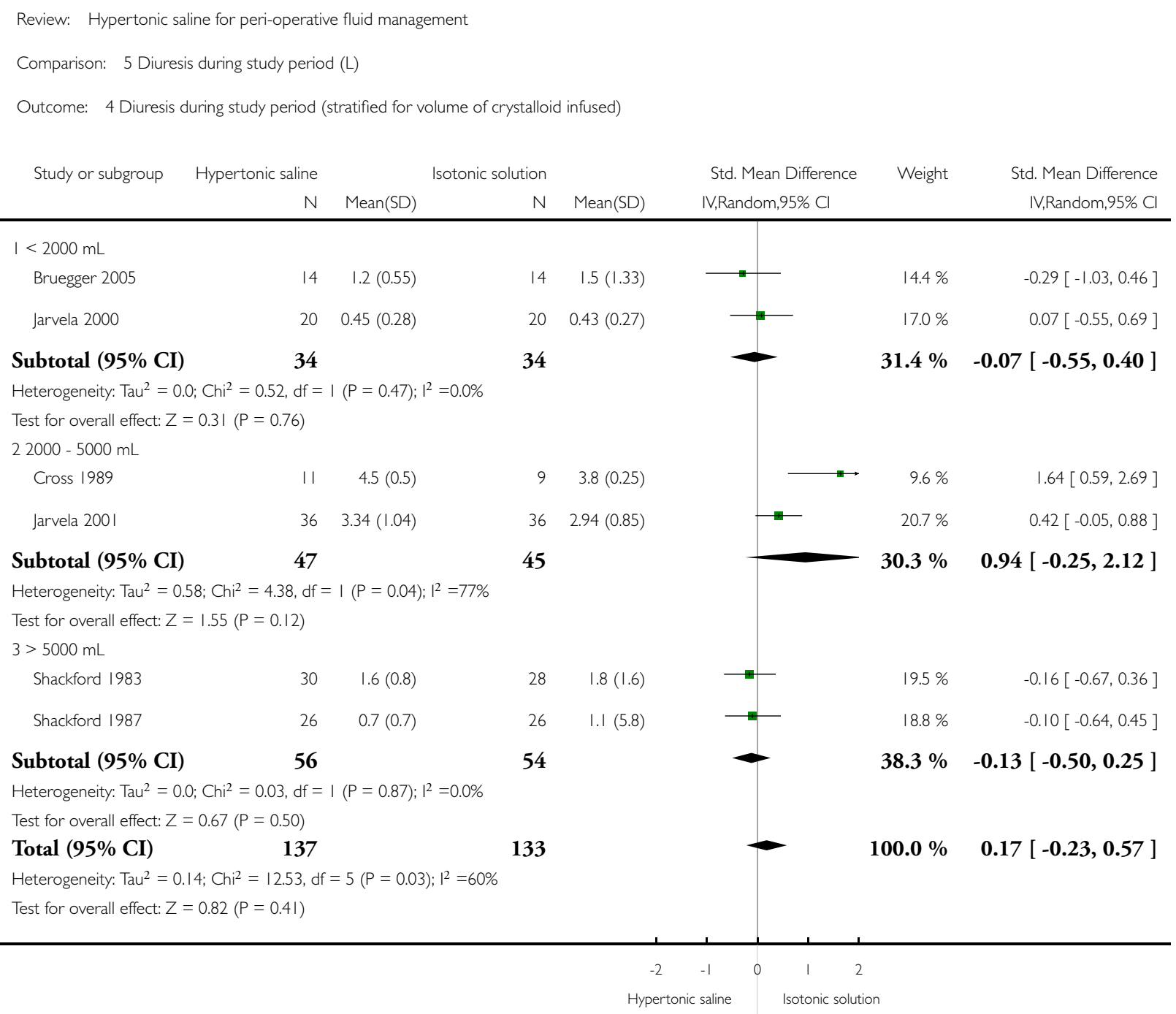


Analysis 5.5. Comparison 5 Diuresis during study period (L), Outcome 5 Diuresis during study period (sensitivity analysis by study quality).

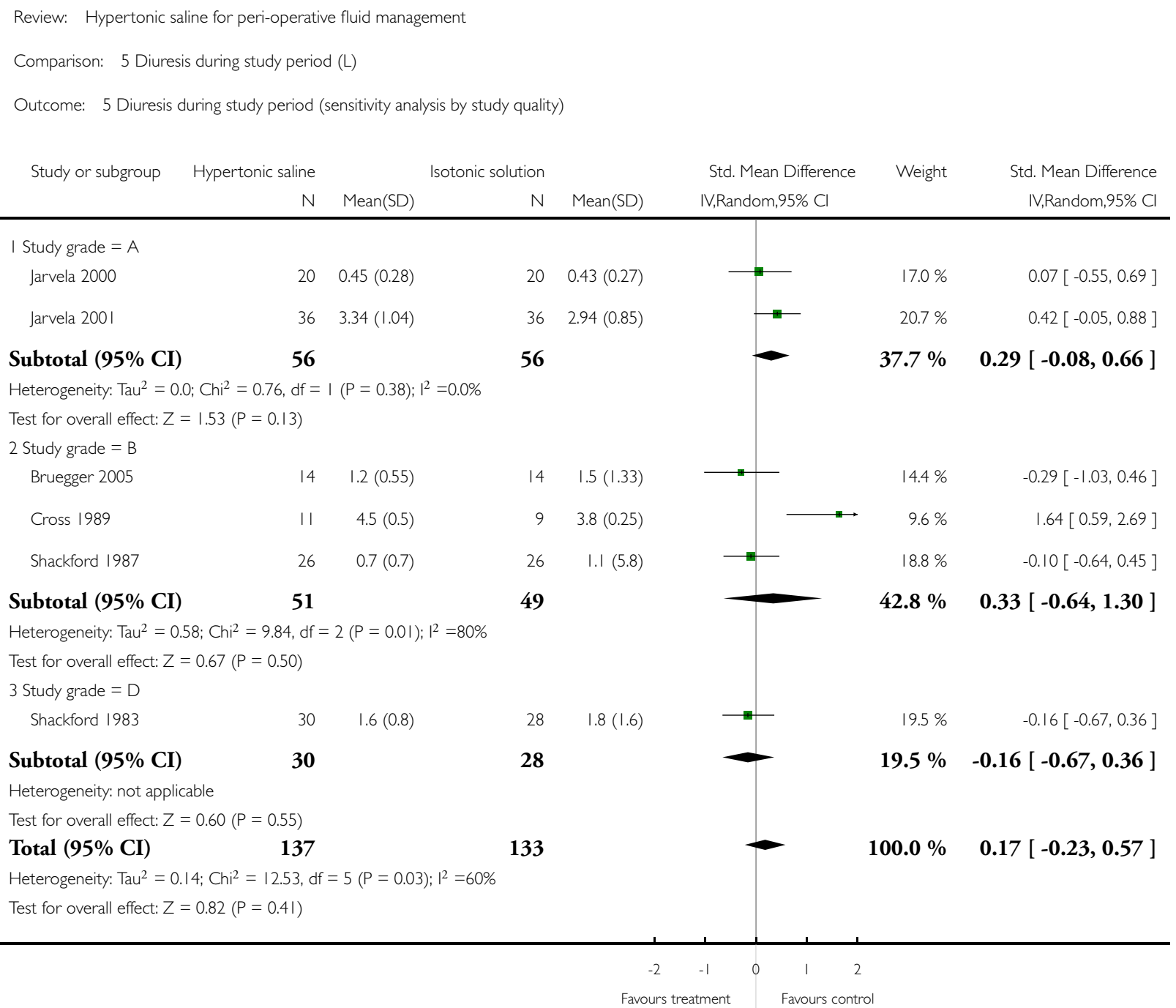




\section{Analysis 6.I. Comparison 6 Peak serum sodium (meq/L), Outcome I Peak serum sodium (stratified by type of surgery).}

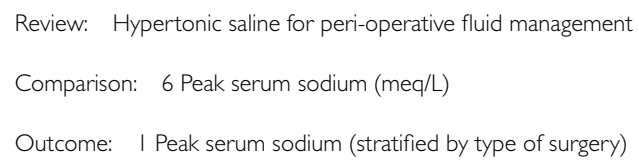

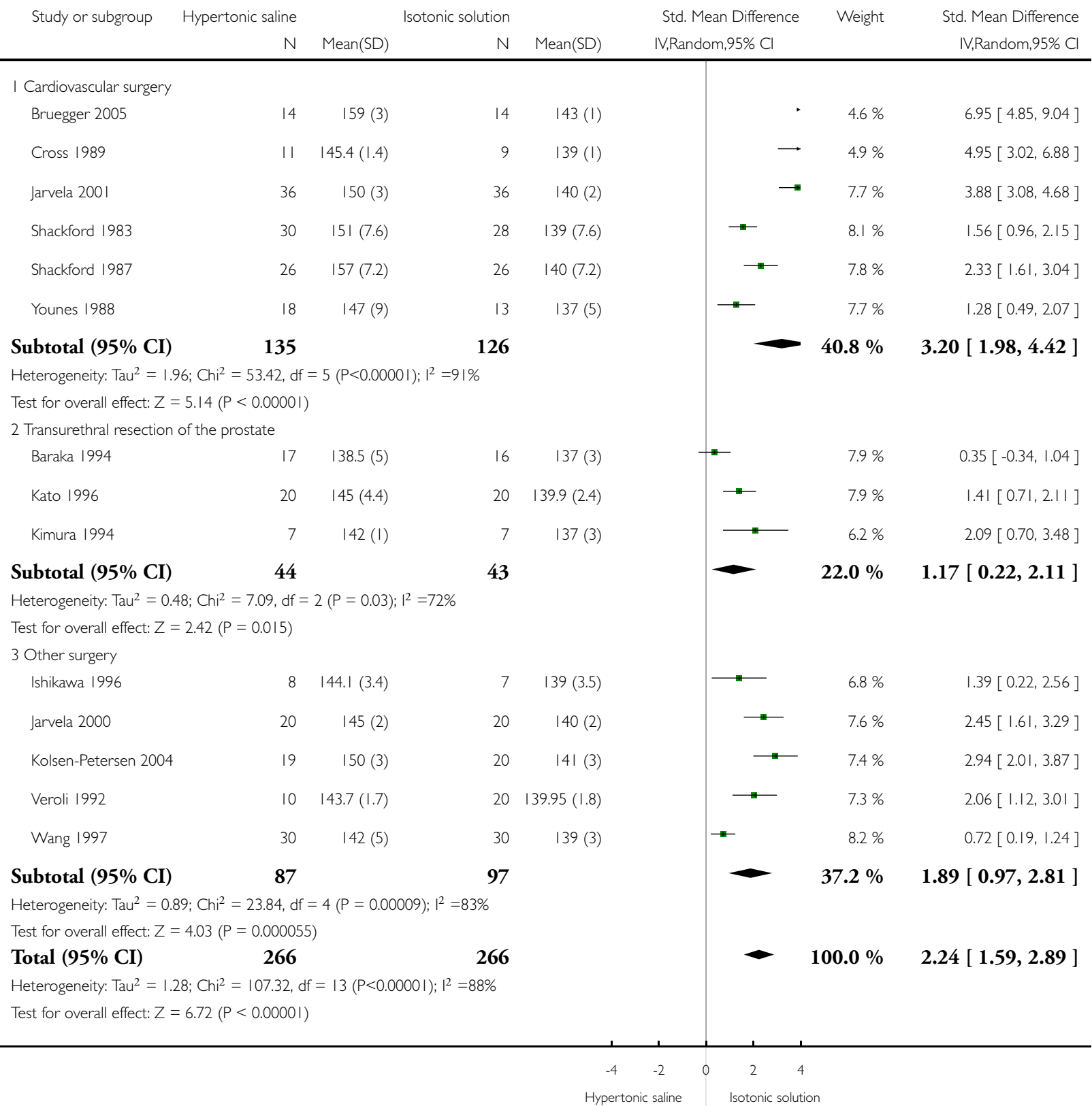




\section{Analysis 6.2. Comparison 6 Peak serum sodium (meq/L), Outcome 2 Peak serum sodium (stratified by dose of HS).}

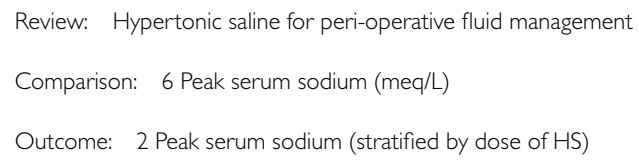

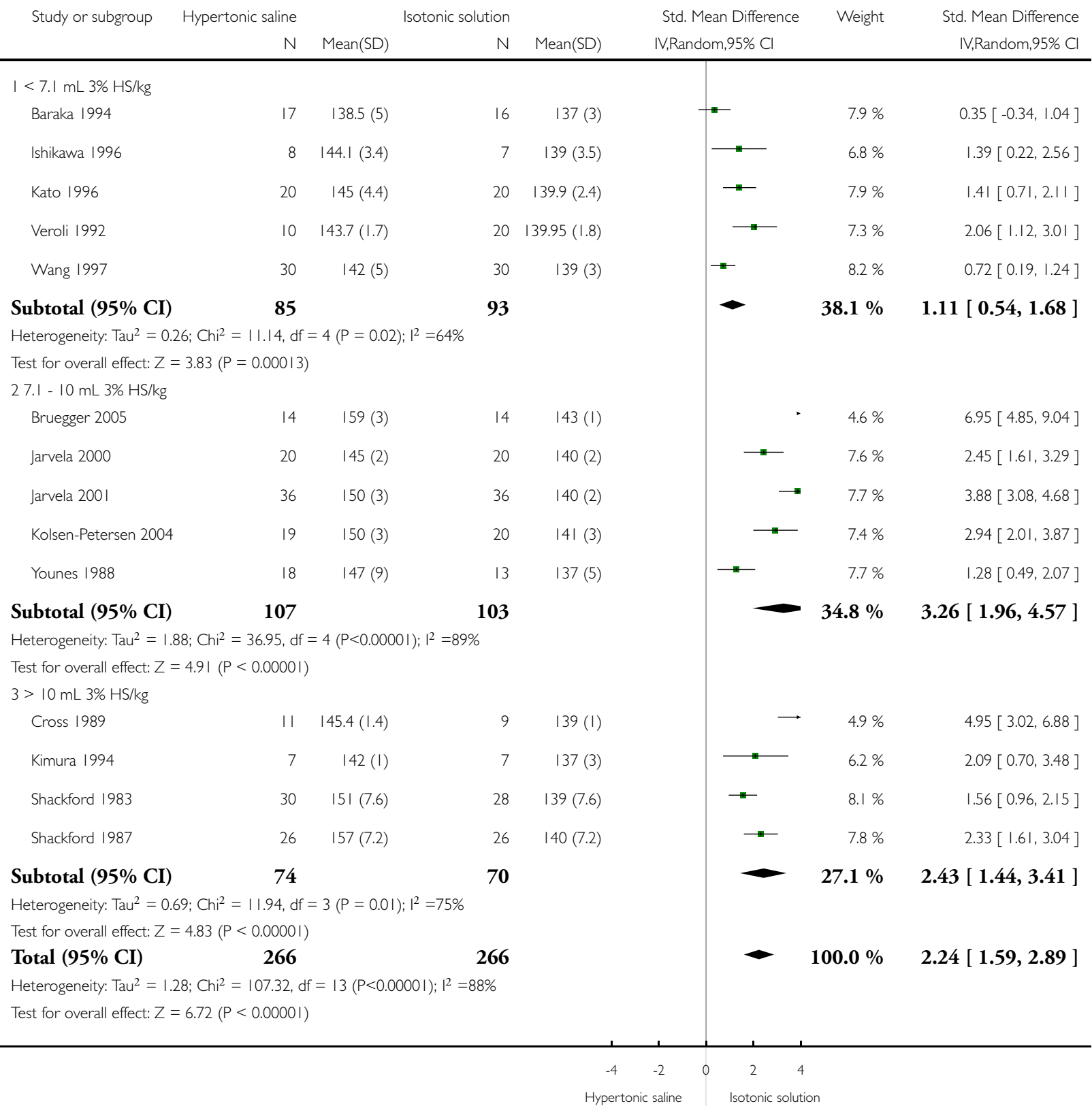


Analysis 6.3. Comparison 6 Peak serum sodium (meq/L), Outcome 3 Peak serum sodium (stratified by volume given in control group).

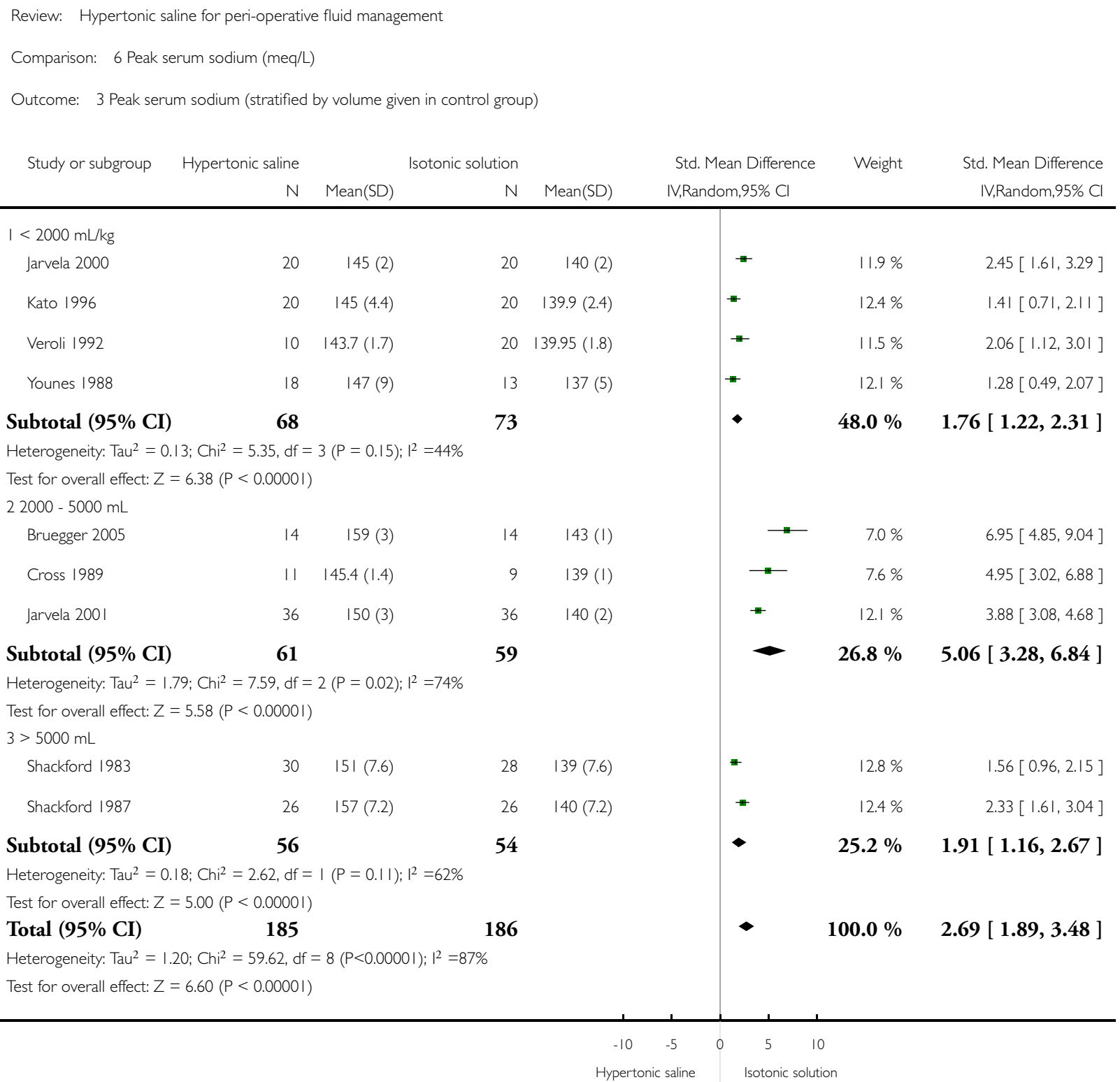


Analysis 6.4. Comparison 6 Peak serum sodium (meq/L), Outcome 4 Peak serum sodium (sensitivity analysis by study quality).

Review: Hypertonic saline for peri-operative fluid management

Comparison: 6 Peak serum sodium (meg/L)

Outcome: 4 Peak serum sodium (sensitivity analysis by study quality)

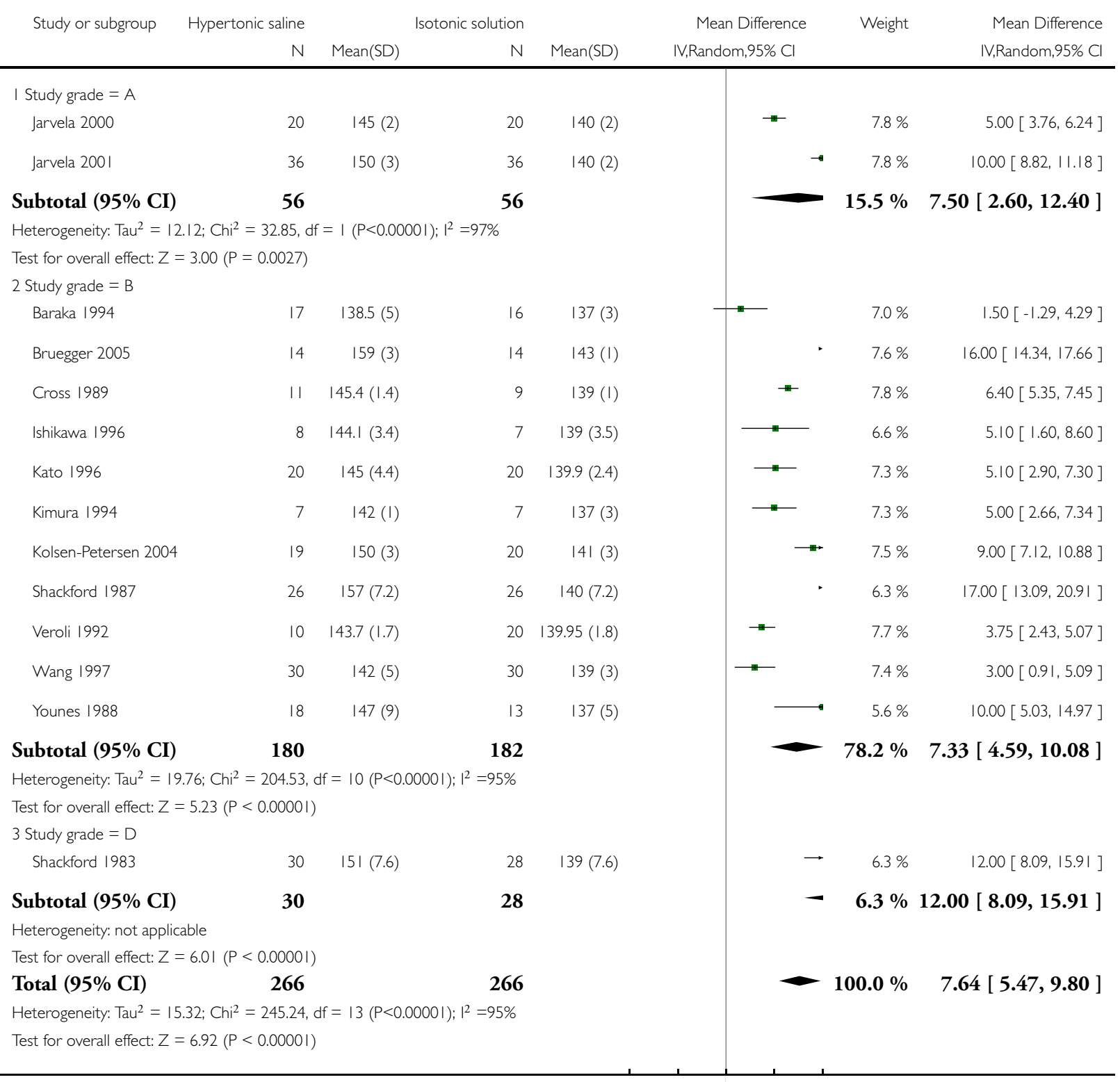

Favours treatment Favours control 
Analysis 7.I. Comparison 7 Final serum sodium (meq/L), Outcome I Final serum sodium (all studies).

Review: Hypertonic saline for peri-operative fluid management

Comparison: 7 Final serum sodium (meq/L)

Outcome: I Final serum sodium (all studies)

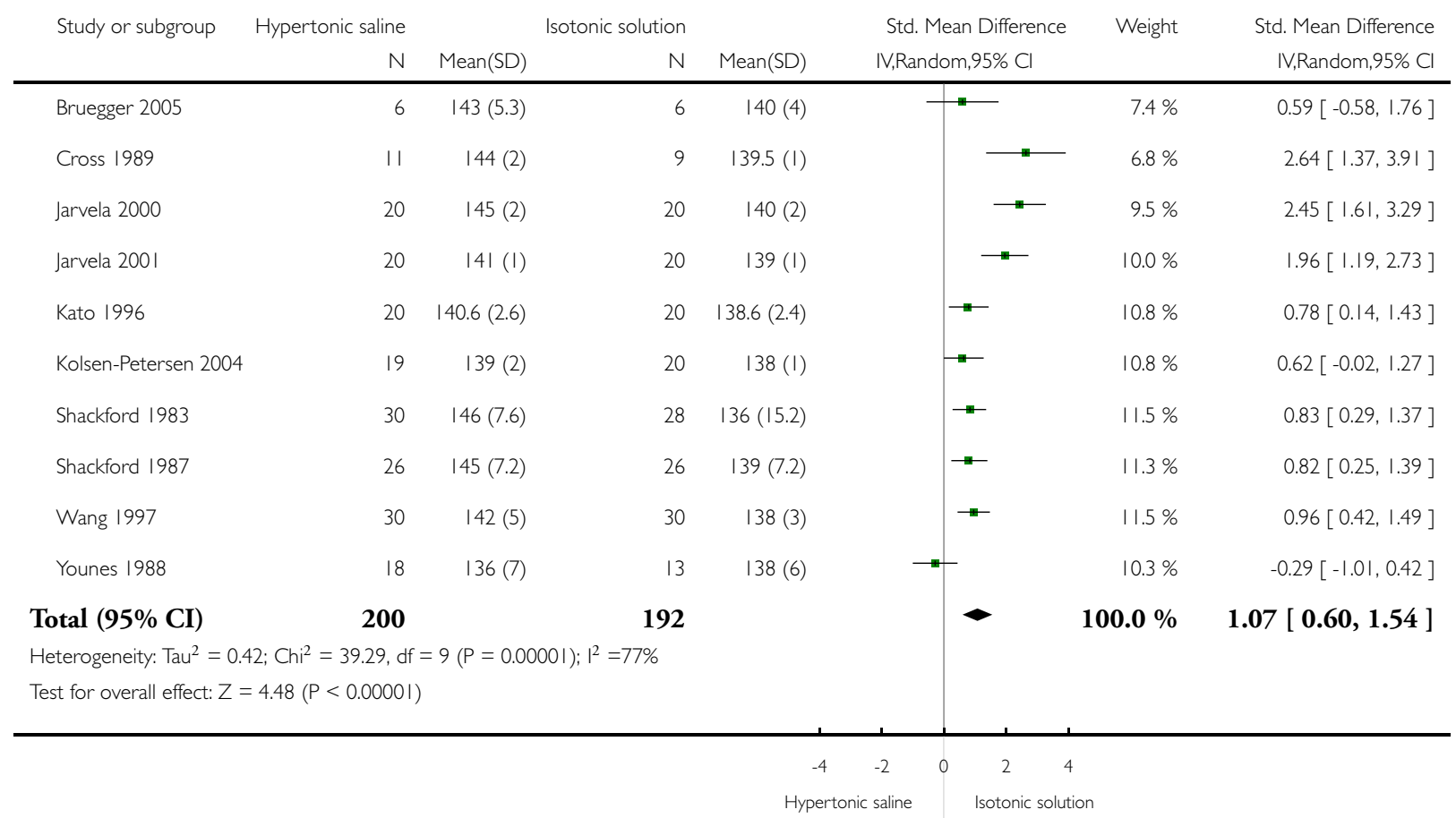




\section{Analysis 7.2. Comparison 7 Final serum sodium (meq/L), Outcome 2 Final serum sodium (stratified by dose of HS given).}

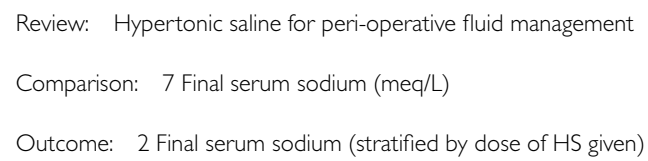

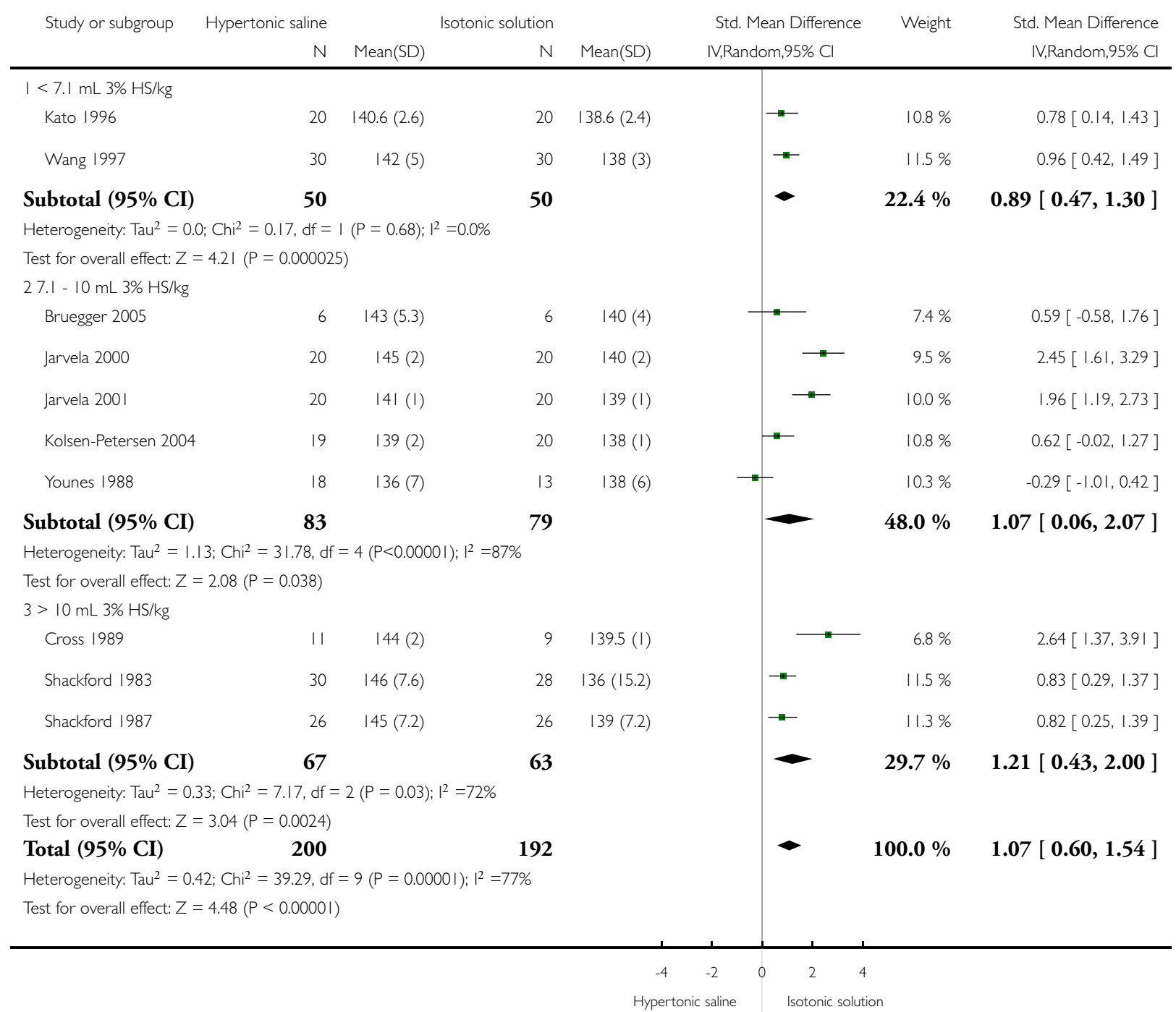


Analysis 7.3. Comparison 7 Final serum sodium (meq/L), Outcome 3 Final serum sodium (stratified by volume given in control group).

Review: Hypertonic saline for peri-operative fluid management

Comparison: 7 Final serum sodium (meq/L)

Outcome: 3 Final serum sodium (stratified by volume given in control group)

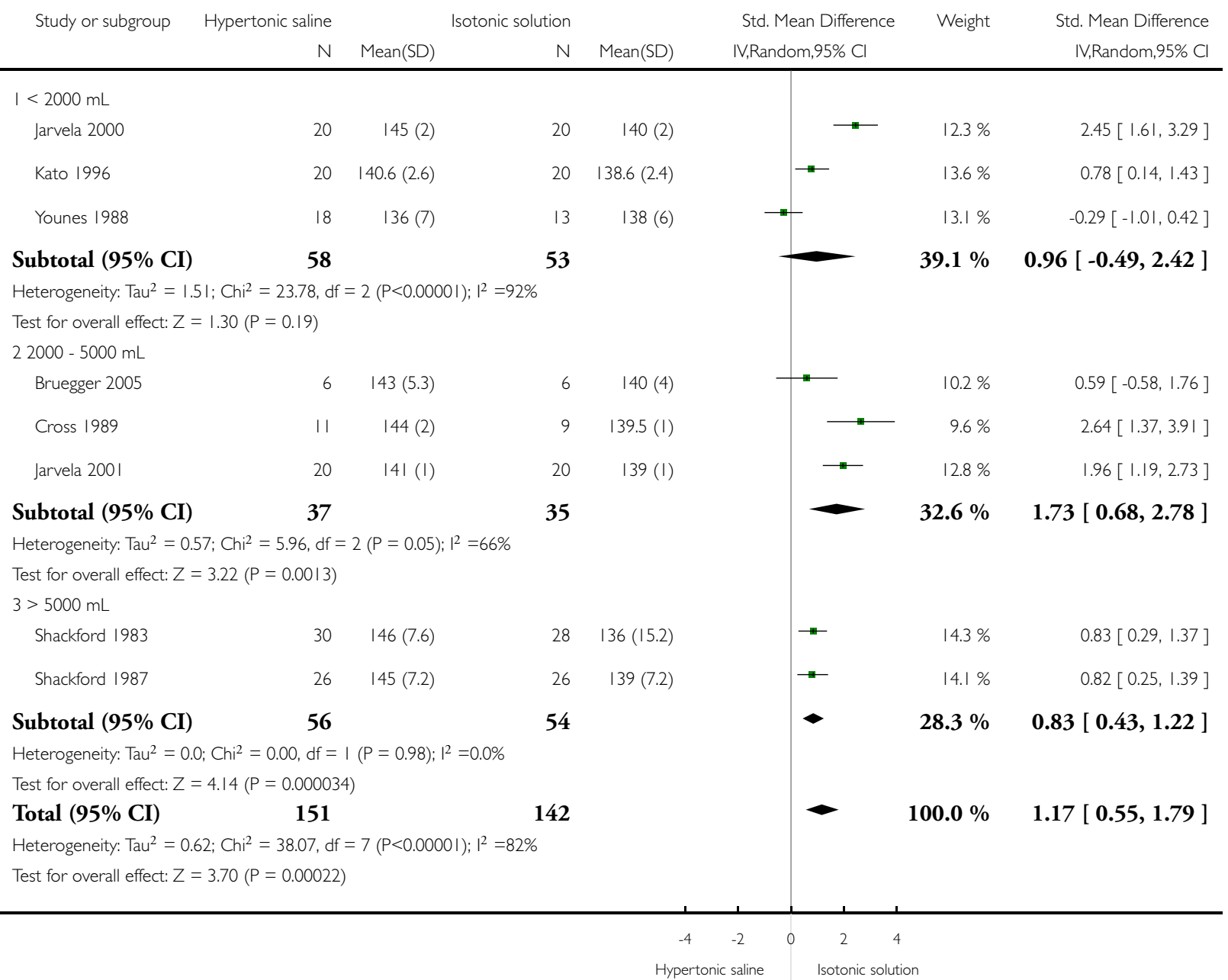




\section{Analysis 7.4. Comparison 7 Final serum sodium (meq/L), Outcome 4 Final serum sodium (stratified by type of surgery).}

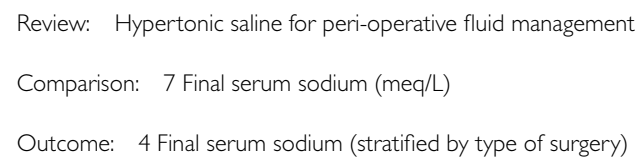

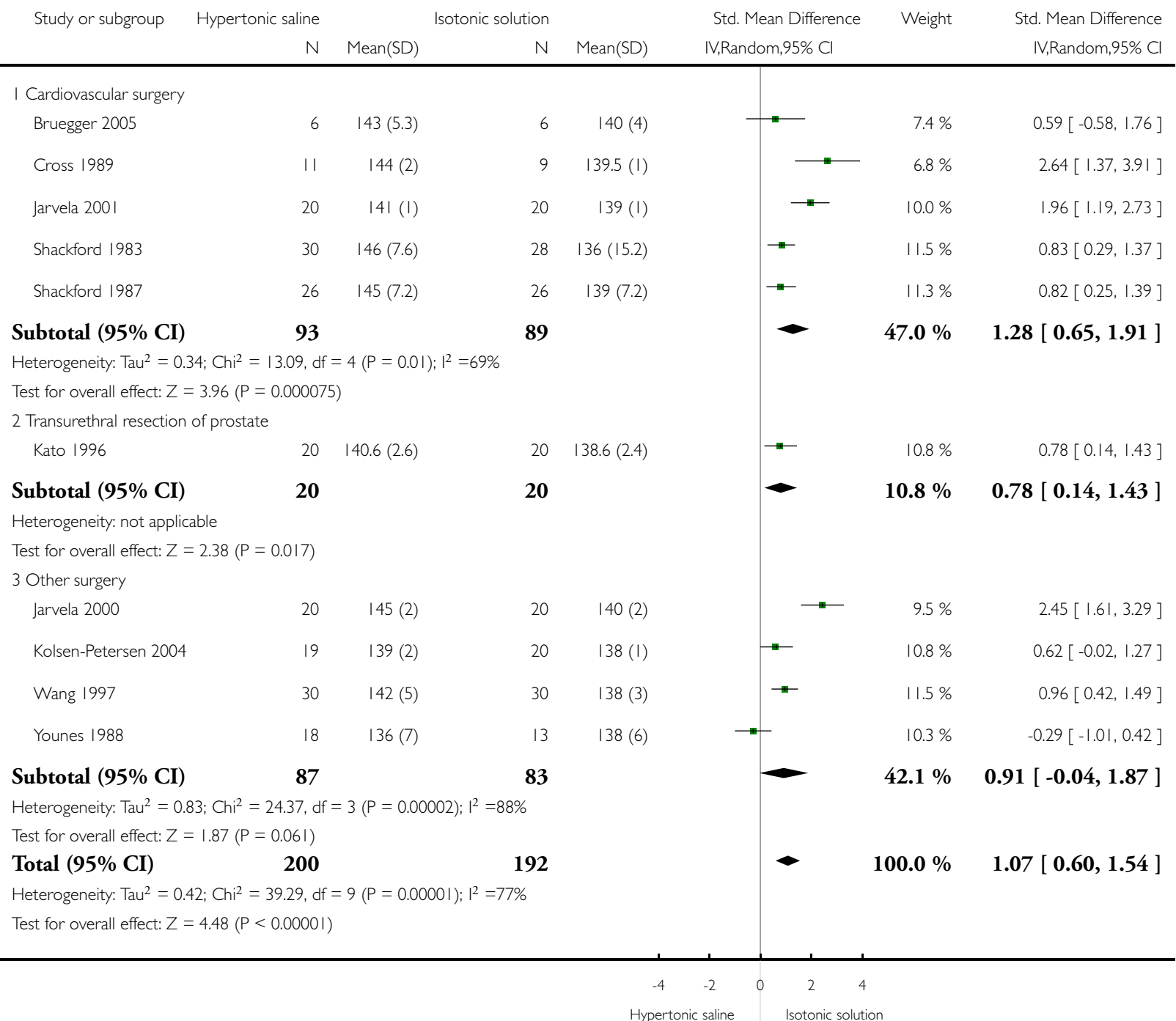


Analysis 7.5. Comparison 7 Final serum sodium (meq/L), Outcome 5 Final serum sodium (sensitivity analysis by study quality).

Review: Hypertonic saline for peri-operative fluid management

Comparison: 7 Final serum sodium (meq/L)

Outcome: 5 Final serum sodium (sensitivity analysis by study quality)

\begin{tabular}{|c|c|c|c|c|c|c|c|}
\hline \multirow[t]{2}{*}{ Study or subgroup } & \multirow{2}{*}{$\begin{array}{r}\text { Hypertonic saline } \\
\text { N }\end{array}$} & \multicolumn{3}{|c|}{ Isotonic solution } & \multirow{2}{*}{$\begin{array}{l}\text { Mean Difference } \\
\text { IV,Random,95\% Cl }\end{array}$} & \multirow[t]{2}{*}{ Weight } & \multirow{2}{*}{$\begin{array}{r}\text { Mean Difference } \\
\text { IV,Random,95\% Cl }\end{array}$} \\
\hline & & Mean(SD) & N & Mean(SD) & & & \\
\hline \multicolumn{8}{|l|}{ I Study grade $=\mathrm{A}$} \\
\hline Jarvela 2000 & 20 & $145(2)$ & 20 & $140(2)$ & & $13.8 \%$ & $5.00[3.76,6.24]$ \\
\hline Jarvela 2001 & 20 & $|4|(1)$ & 20 & $139(1)$ & $\rightarrow$ & $15.3 \%$ & $2.00[1.38,2.62]$ \\
\hline Subtotal $(95 \% \mathrm{CI})$ & 40 & & 40 & & & $29.2 \%$ & $3.45[0.51,6.39]$ \\
\hline \multicolumn{8}{|c|}{ Heterogeneity: $\mathrm{Tau}^{2}=4.25 ; \mathrm{Chi}^{2}=18.00, \mathrm{df}=\mid(\mathrm{P}=0.00002) ; \mathrm{I}^{2}=94 \%$} \\
\hline \multicolumn{8}{|c|}{ Test for overall effect: $Z=2.30(P=0.021)$} \\
\hline \multicolumn{8}{|l|}{2 Study grade $=B$} \\
\hline Bruegger 2005 & 6 & $143(5.3)$ & 6 & $140(4)$ & & $4.2 \%$ & $3.00[-2.31,8.31]$ \\
\hline Cross 1989 & 11 & $144(2)$ & 9 & $139.5(1)$ & & $13.5 \%$ & $4.50[3.15,5.85]$ \\
\hline Kato 1996 & 20 & $140.6(2.6)$ & 20 & $138.6(2.4)$ & $\longrightarrow$ & $12.9 \%$ & $2.00[0.45,3.55]$ \\
\hline Kolsen-Petersen 2004 & 19 & $139(2)$ & 20 & $138(1)$ & 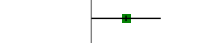 & $14.5 \%$ & $1.00[0.00,2.00]$ \\
\hline Shackford 1987 & 26 & $145(7.2)$ & 26 & $139(7.2)$ & & $6.3 \%$ & $6.00[2.09,9.91]$ \\
\hline Wang 1997 & 30 & $142(5)$ & 30 & $138(3)$ & & $11.1 \%$ & $4.00[1.91,6.09]$ \\
\hline Younes 1988 & 18 & $136(7)$ & 13 & $138(6)$ & & $5.1 \%$ & $-2.00[-6.59,2.59]$ \\
\hline Subtotal (95\% CI) & 130 & & 124 & & & $-\quad 67.6 \%$ & $2.74[1.11,4.38]$ \\
\hline \multicolumn{8}{|c|}{ Heterogeneity: $\operatorname{Tau}^{2}=3.11$; $\mathrm{Chi}^{2}=26.15, \mathrm{df}=6(\mathrm{P}=0.00021) ; \mathrm{I}^{2}=77 \%$} \\
\hline \multicolumn{8}{|c|}{ Test for overall effect: $Z=3.28(P=0.00 \mid 0)$} \\
\hline \multicolumn{8}{|l|}{3 Study grade $=\mathrm{D}$} \\
\hline Shackford 1983 & 30 & $146(7.6)$ & 28 & $136(15.2)$ & & $3.3 \%$ & $10.00[3.75,16.25]$ \\
\hline Subtotal (95\% CI) & 30 & & 28 & & & $3.3 \%$ & $10.00[3.75,16.25]$ \\
\hline \multicolumn{8}{|c|}{ Heterogeneity: not applicable } \\
\hline \multicolumn{8}{|c|}{ Test for overall effect: $Z=3.13(P=0.0017)$} \\
\hline Total (95\% CI) & 200 & & 192 & & & $-100.0 \%$ & $3.18[1.91,4.44]$ \\
\hline \multicolumn{8}{|c|}{ Heterogeneity: Tau $^{2}=2.61 ;$ Chi $^{2}=49.84, d f=9(P<0.0000 I) ; I^{2}=82 \%$} \\
\hline Test for overall effect: $Z=$ & $=4.92(P<0.00001)$ & & & & & & \\
\hline
\end{tabular}

Favours treatment Favours control 
Analysis 12.I. Comparison 12 Other outcomes of interest, Outcome I Maximum intraoperative serum osmolarity (mOsm/kg H2O).

Review: Hypertonic saline for peri-operative fluid management

Comparison: 12 Other outcomes of interest

Outcome: I Maximum intraoperative serum osmolarity $(\mathrm{mOsm} / \mathrm{kg} \mathrm{H} 2 \mathrm{O})$

\begin{tabular}{|c|c|c|c|c|c|c|c|}
\hline \multirow[t]{2}{*}{ Study or subgroup } & \multirow{2}{*}{$\begin{array}{r}\text { Hypertonic saline } \\
\mathrm{N}\end{array}$} & \multicolumn{3}{|c|}{ Isotonic solution } & \multirow{2}{*}{$\begin{array}{l}\text { Std. Mean Difference } \\
\text { IV,Random,95\% Cl }\end{array}$} & \multirow[t]{2}{*}{ Weight } & \multirow{2}{*}{$\begin{array}{l}\text { Std. Mean Difference } \\
\text { IV,Random,95\% Cl }\end{array}$} \\
\hline & & Mean(SD) & N & Mean(SD) & & & \\
\hline Ishikawa 1996 & 8 & $295.8(4.4)$ & 7 & $281.5(10.2)$ & $\rightarrow$ & $10.8 \%$ & $1.76[0.51,3.01]$ \\
\hline Jarvela 2000 & 20 & $302(5)$ & 20 & $292(3)$ & 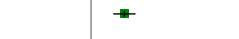 & $12.0 \%$ & $2.38[1.55,3.20]$ \\
\hline Jarvela 2001 & 20 & $313(6)$ & 20 & $290(4)$ & $\rightarrow$ & $11.0 \%$ & $4.42[3.23,5.61]$ \\
\hline Kato 1996 & 20 & $298.2(6.1)$ & 20 & $284.3(3.5)$ & - & $11.8 \%$ & $2.74[1.85,3.62]$ \\
\hline Kimura 1994 & 7 & $296(4)$ & 7 & $287(7)$ & $\rightarrow$ & $10.9 \%$ & $1.48[0.25,2.7 \mid]$ \\
\hline Kolsen-Petersen 2004 & 19 & $302(2)$ & 20 & $285(0.5)$ & $\rightarrow$ & $6.4 \%$ & II.56 [8.78, 14.34$]$ \\
\hline Shackford 1983 & 30 & $301(15.2)$ & 28 & $284(7.6)$ & 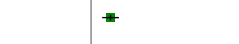 & $12.5 \%$ & $1.38[0.80,1.96]$ \\
\hline Shackford 1987 & 26 & $309(14.4)$ & 26 & $284(7.2)$ & \# & $12.3 \%$ & $2.16[1.47,2.86]$ \\
\hline Younes 1988 & 18 & $327(11)$ & 13 & $320(8)$ & 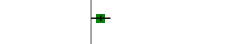 & $12.2 \%$ & $0.69[-0.05,1.43]$ \\
\hline Total (95\% CI) & 168 & & 161 & & $<$ & $100.0 \%$ & $2.72[1.73,3.71]$ \\
\hline \multicolumn{8}{|c|}{ Heterogeneity: $\mathrm{Tau}^{2}=1.95 ; \mathrm{Chi}^{2}=82.38, \mathrm{df}=8(\mathrm{P}<0.0000 \mathrm{I}) ; \mathrm{I}^{2}=90 \%$} \\
\hline \multicolumn{8}{|c|}{ Test for overall effect: $Z=5.38(P<0.0000 \mathrm{I})$} \\
\hline
\end{tabular}




\section{Analysis 12.2. Comparison 12 Other outcomes of interest, Outcome 2 Maximum intraoperative pulmonary} artery wedge pressure $(\mathrm{mm} \mathrm{Hg})$.

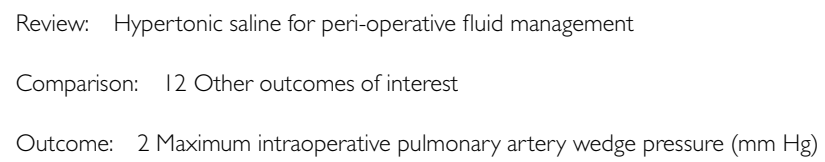

\begin{tabular}{|c|c|c|c|c|c|c|c|}
\hline \multirow[t]{2}{*}{ Study or subgroup } & Hypertonic saline & \multicolumn{3}{|c|}{ Isotonic solution } & \multirow{2}{*}{$\begin{array}{l}\text { Std. Mean Difference } \\
\text { IV,Random,95\% Cl }\end{array}$} & \multirow[t]{2}{*}{ Weight } & \multirow{2}{*}{$\begin{array}{l}\text { Std. Mean Difference } \\
\quad \text { IV,Random, } 95 \% \mathrm{Cl}\end{array}$} \\
\hline & N & Mean(SD) & N & Mean(SD) & & & \\
\hline Jarvela 2001 & 20 & $9.1(3.5)$ & 20 & $8.4(4.5)$ & $T$ & $26.6 \%$ & $0.17[-0.45,0.79]$ \\
\hline Shackford 1983 & 30 & $10(7.6)$ & 28 & II (7.6) & $\rightarrow$ & $38.6 \%$ & $-0.13[-0.65,0.39]$ \\
\hline Shackford 1987 & 26 & II (7.2) & 26 & II (7.2) & 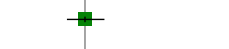 & $34.7 \%$ & $0.0[-0.54,0.54]$ \\
\hline Total $(95 \% \mathrm{CI})$ & 76 & & 74 & & 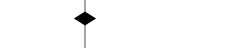 & $100.0 \%$ & $0.00[-0.33,0.32]$ \\
\hline \multicolumn{8}{|c|}{ Heterogeneity: $\operatorname{Tau}^{2}=0.0 ; \mathrm{Chi}^{2}=0.53, \mathrm{df}=2(P=0.77) ; \mathrm{I}^{2}=0.0 \%$} \\
\hline \multicolumn{8}{|c|}{ Test for overall effect: $Z=0.03(P=0.98)$} \\
\hline
\end{tabular}

Analysis 12.3. Comparison 12 Other outcomes of interest, Outcome 3 Maximum intraoperative cardiac index (L/min/M2).

Review: Hypertonic saline for peri-operative fluid management

Comparison: 12 Other outcomes of interest

Outcome: 3 Maximum intraoperative cardiac index ( $/ \mathrm{min} / \mathrm{M} 2)$

\begin{tabular}{|c|c|c|c|c|c|c|c|}
\hline \multirow[t]{2}{*}{ Study or subgroup } & Hypertonic saline & \multicolumn{3}{|c|}{ Isotonic solution } & \multirow{2}{*}{$\begin{array}{l}\text { Std. Mean Difference } \\
\text { IV,Random, } 95 \% \mathrm{Cl}\end{array}$} & \multirow[t]{2}{*}{ Weight } & \multirow{2}{*}{$\begin{array}{r}\text { Std. Mean Difference } \\
\text { IV,Random, } 95 \% \mathrm{CI}\end{array}$} \\
\hline & N & Mean(SD) & N & Mean(SD) & & & \\
\hline Cross 1989 & 11 & $3.1(0.3)$ & 9 & $2.65(0.3)$ & $\longrightarrow$ & $12.6 \%$ & $1.44[0.43,2.45]$ \\
\hline Jarvela 2000 & 20 & $3.19(0.5)$ & 20 & $3.02(0.65)$ & 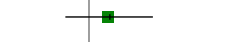 & $20.9 \%$ & $0.29[-0.34,0.91]$ \\
\hline Jarvela 2001 & 20 & $3.2(1)$ & 20 & $2.3(0.5)$ & $\mp$ & $19.6 \%$ & $1.12[0.44,1.79]$ \\
\hline Shackford 1983 & 30 & $3.1(0.8)$ & 28 & $3(0.8)$ & $\mp$ & $23.9 \%$ & $0.12[-0.39,0.64]$ \\
\hline Shackford 1987 & 26 & $3.7(1.2)$ & 26 & $3.4(1.2)$ & 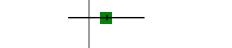 & $23.0 \%$ & $0.25[-0.30,0.79]$ \\
\hline Total $(95 \% \mathrm{CI})$ & 107 & & 103 & & $\longrightarrow$ & $100.0 \%$ & $0.55[0.10,1.00]$ \\
\hline \multicolumn{8}{|c|}{ Heterogeneity: $\mathrm{Tau}^{2}=0.15 ; \mathrm{Ch}^{2}=9.77, \mathrm{df}=4(\mathrm{P}=0.04) ;\left.\right|^{2}=59 \%$} \\
\hline \multicolumn{8}{|c|}{ Test for overall effect: $Z=2.38(P=0.017)$} \\
\hline
\end{tabular}




\section{A P P E N D I CES}

\section{Appendix I. MEDLINE (1966 to April 2007)}

\#1 explode saline solution, hypertonic/all subheadings

\#2 explode hypertonic solutions/all subheadings

\#3 (hypertonic $\mathrm{NaCl}$ ) or (hypertonic saline) or (hypertonic solution*)

\#4 Ringer's solution/ all subheadings

$\# 5 \# 1$ or $\# 2$ or \#3 or \#4

\#6 \#5 not (explode glucose solution, hypertonic / all subheadings)

\#7 \#6 not colloid*

\#8 explode surgical procedures, operative/all subheadings

\#9 explode specialties, surgical/ all subheadings

\#10 explode surgery/ all subheadings

\#11 (surg* near procedur*) or surger* or operat*

$\# 12 \# 8$ or $\# 9$ or \#10 or \#11

$\# 13$ \#7 and \#12

\#14 RANDOMIZED-CONTROLLED-TRIAL in PT

\#15 CONTROLLED-CLINICAL-TRIAL in PT

\#16 explode RANDOMIZED-CONTROLLED-TRIALS/all subheadings

\#17 explode RANDOM-ALLOCATION/all subheadings

\#18 explode DOUBLE-BLIND-METHOD/all subheadings

\#19 explode SINGLE-BLIND-METHOD/all subheadings

\#20 \#14 or \#15 or \#16 or \#17 or \#18 or \#19

\#21 (TG=ANIMALS) not ((TG=HUMAN) and (TG=ANIMALS))

\#22 \#20 not \#21

\#23 CLINICAL-TRIAL in PT

\#24 explode CLINICAL-TRIALS / all subheadings

\#25 (clin* near trial*) in TI

\#26 (clin* near trial*) in AB

\#27 (singl* or doubl* or trebl* or tripl*) near (blind* or mask ${ }^{*}$ )

$\# 28$ (\#27 in TI) or (\#27 in $\mathrm{AB}$ )

\#29 explode PLACEBOS/ all subheadings

\#30 placebo* in TI

\#31 placebo* in $\mathrm{AB}$

$\# 32$ random* in TI

\#33 random* in $\mathrm{AB}$

\#34 explode RESEARCH-DESIGN/all subheadings

$\# 35 \# 23$ or $\# 24$ or $\# 25$ or $\# 26$ or \#27 or \#28 or \#29 or \#30 or \#31 or \#32 or \#33

or \#34

\#36 (TG=ANIMALS) not ((TG=HUMAN) and (TG=ANIMALS))

\#37 \#35 not \#36

\#38 \#37 not \#22

\#39 TG=COMPARATIVE-STUDY

\#40 explode EVALUATION-STUDIES/all subheadings

\#41 explode FOLLOW-UP-STUDIES/all subheadings

\#42 explode PROSPECTIVE-STUDIES/all subheadings

\#43 control* $^{*}$ or prospectiv* or volunteer*

$\# 44(\# 43$ in $\mathrm{TI})$ or $(\# 43$ in $\mathrm{AB})$

$\# 45 \# 39$ or \#40 or \#41 or \#42 or \#43 or \#44

\#46 (TG=ANIMALS) not ((TG=HUMAN) and (TG=ANIMALS))

\#47 \#45 not \#46

\#48 \#47 not (\#22 or \#38)

Hypertonic saline for peri-operative fluid management (Review)

Copyright (C) 2010 The Cochrane Collaboration. Published by John Wiley \& Sons, Ltd. 
\#49 \#22 or \#38 or \#48

\#50 \#13 and \#49

\section{Appendix 2. EMBASE (1980 to 2007 week 18)}

$\# 1$ saline solution

\#2 explode "hypertonic-solution" / all SUBHEADINGS in DEM,DER,DRM,DRR

\#3 (hypertonic $\mathrm{NaCl}$ ) or (hypertonic saline) or (hypertonic solution*)

\#4 "Ringer-solution" / all SUBHEADINGS in DEM,DER,DRM,DRR

\#5 sodium chloride in $\mathrm{TI}, \mathrm{AB}$

$\# 6$ \#1 or \#2 or \#3 or \#4 or \#5

$\# 7$ \#6 not (glucose or fructose)

\#8 explode surgery/all subheadings

\#9 (surg* $^{*}$ near procedur*) or surger* or operat*

\#10 "surgical-technique" / all SUBHEADINGS in DEM,DER,DRM,DRR

$\# 11$ \#8 or \#9 or \#10

$\# 12$ \#7 and \#11

\#13 explode "randomized-controlled-trial" / all SUBHEADINGS in DEM,DER,DRM,DRR

\#14 (randomi?ed controlled trial ${ }^{*}$ ) in TI, AB

\#15 random*

\#16 explode "randomization-" / all SUBHEADINGS in DEM,DER,DRM,DRR

\#17 randomi?ation

\#18 explode "clinical-trial" / all SUBHEADINGS in DEM,DER,DRM,DRR

\#19 clinical near trial*

\#20 explode multicenter-study / all subheadings

\#21 multi?cent*

\#22 explode phase-4-clinical-trial / all subheadings or explode double-blind-procedure / all subheadings or explode single-blindprocedure / all subheadings

\#23 (RANDOM* ${ }^{*}$ or CROSS?OVER* or FACTORIAL* or PLACEBO* or VOLUNTEER*) in TI, AB, TW

\#24 ((SINGL* or DOUBL* or TREBL* or TRIPL*) near (BLIND* or MASK*)) in TI,AB

$\# 25 \# 13$ or $\# 14$ or $\# 15$ or \#16 or \#17 or \#18 or \#19 or \#20 or \#21 or \#22 or \#23 or \#24

\#26 (human) in DER

\#27 (animal or nonhuman) in DER

$\# 28$ \#26 and \#27

\#29 \#27 not \#28

\#30 \#25 not \#29

$\# 31$ \#12 and \#30

\section{Appendix 3. CINAHL (1982 to April week I, 2007)}

\#1 explode "Saline-Solution-Hypertonic" / all TOPICAL SUBHEADINGS / all AGE SUBHEADINGS in DE \#2 explode "Hypertonic-Solutions" / all TOPICAL SUBHEADINGS / all AGE SUBHEADINGS in DE

\#3 (hypertonic $\mathrm{NaCl}$ ) or (hypertonic saline) or (hypertonic solution*)

\#4 explode "Lactated-Ringer's-Solution" / all TOPICAL SUBHEADINGS / all AGE SUBHEADINGS in DE

\#5 explode "Sodium-Chloride" / all TOPICAL SUBHEADINGS / all AGE SUBHEADINGS in DE

$\# 6$ \#1 or \#2 or \#3 or \#4 or \#5

\#7 \#6 not (glucose or fructose)

\#8 explode "Surgery-Operative" / all TOPICAL SUBHEADINGS / all AGE SUBHEADINGS in DE

\#9 (surg* near procedur*) or (surg* and procedur*)or surger* or operat*

$\# 10 \# 8$ or \#9

$\# 11 \# 7$ and \#10

\#12 Randomized Clinical Trial*

Hypertonic saline for peri-operative fluid management (Review)

Copyright (C) 2010 The Cochrane Collaboration. Published by John Wiley \& Sons, Ltd. 
\#13 Controlled Clinical Trial*

\#14 explode "Random-Assignment" / all TOPICAL SUBHEADINGS / all AGE SUBHEADINGS in DE

\#15 "Double-Blind-Studies" / all TOPICAL SUBHEADINGS / all AGE SUBHEADINGS in DE

\#16 "Single-Blind-Studies" / all TOPICAL SUBHEADINGS / all AGE SUBHEADINGS in DE

\#17 explode "Clinical-Trials" / all TOPICAL SUBHEADINGS / all AGE SUBHEADINGS in DE

\#18 (clin* near trial*) in TI

$\# 19$ (clin* near trial*) in $\mathrm{AB}$

\#20 (singl* ${ }^{*}$ or doubl* or trebl* or tripl*) near (blind* or mask*)

$\# 21$ (\#20 in $\mathrm{TI})$ or $(\# 20$ in $\mathrm{AB})$

\#22 "Placebos-" / all TOPICAL SUBHEADINGS / all AGE SUBHEADINGS in DE

\#23 placebo* in TI

\#24 placebo* $^{*}$ in $\mathrm{AB}$

$\# 25$ random* in TI

$\# 26$ random* in $\mathrm{AB}$

\#27 “Study-Design" / all TOPICAL SUBHEADINGS / all AGE SUBHEADINGS in DE

\#28 "Comparative-Studies" / all TOPICAL SUBHEADINGS / all AGE SUBHEADINGS in DE

\#29 explode "Evaluation-Research" / all TOPICAL SUBHEADINGS / all AGE SUBHEADINGS in DE

\#30 "Prospective-Studies" / all TOPICAL SUBHEADINGS / all AGE SUBHEADINGS in DE

$\# 31$ control* or prospectiv* or volunteer*

$\# 32 \# 12$ or $\# 13$ or \#14 or \#15 or \#16 or \#17 or \#18 or \#19 or \#20 or \#21 or \#22 or \#23 or \#24 or \#25 or \#26 or \#27 or \#28 or \#29

or \#30 or \#31

\#33 sheep or dog* or cat* or guinea?pig* or mouse or experimental animal*

\#34 explode animals/ all topical subheadings / all age subheadings

$\# 35$ \#33 or \#34

$\# 36$ human*

$\# 37$ \#35 not (\#34 and \#35)

$\# 38 \# 32$ not \#37

$\# 39$ \#11 and \#38

\section{Appendix 4. LILACS (1 982 to April 2007)}

"HYPERTONIC" or "HYPERTONIC SALINE SOLUTION/" or "HYPERTONIC SOLUTION, SALINE/" or "HYPERTONIC SOLUTIONS/" or "RINGER" or "SODIUM CHLORIDE" or "SODIUM CHLORIDE SOLUTION, HYPERTONIC/" [Words] and "SURGERY" or "SURGICAL" or "OPERATION" or "surg\$" or "operat\$” [Words]

\section{Appendix 5. CENTRAL, (The Cochrane Library, 2007 Issue I)}

\#1 MeSH descriptor Sodium Chloride explode all trees \#2 MeSH descriptor Saline Solution, Hypertonic explode all trees \#3 ( (hypertonic in All Text and $\mathrm{NaCl}$ in All Text) or (hypertonic in All Text and saline in All Text) or (hypertonic in All Text and solution* in All Text) )

\#4 (Ringer's in All Text and solution in All Text)

$\# 5$ (\#1 or \#2 or \#3 or \#4)

\#6 MeSH descriptor Glucose Solution, Hypertonic explode all trees

\#7 (\#5 and not \#6)

\#8 (\#7 and not colloid* in All Text)

\#9 $\mathrm{MeSH}$ descriptor surgical procedures, operative explode all trees

\#10 MeSH descriptor Specialties, Surgical explode all trees

\#11 MeSH descriptor Specialties, Dental explode all trees

\#12 MeSH descriptor Surgery explode all trees

\#13 (surg* in All Text near/6 procedur* in All Text)

\#14 (surger* in All Text or operat* in All Text)

Hypertonic saline for peri-operative fluid management (Review)

Copyright $(2010$ The Cochrane Collaboration. Published by John Wiley \& Sons, Ltd. 
$\# 15$ (\#9 or \#10 or \#11 or \#12 or \#13 or \#14)

\#16 (\#8 and \#15)

5 not \#36

\#38 \#37 not \#22

\#39 TG=COMPARATIVE-STUDY

\#40 explode EVALUATION-STUDIES/all subheadings

\#41 explode FOLLOW-UP-STUDIES/all subheadings

\#42 explode PROSPECTIVE-STUDIES/all subheadings

\#43 control* or prospectiv* or volunteer*

\#44 (\#43 in TI) or (\#43 in $\mathrm{AB})$

$\# 45 \# 39$ or \#40 or \#41 or \#42 or \#43 or \#44

\#46 (TG=ANIMALS) not ((TG=HUMAN) and (TG=ANIMALS))

\#47 \#45 not \#46

\#48 \#47 not (\#22 or \#38)

\#49 \#22 or \#38 or \#48

\#50 \#13 and \#49

\section{Appendix 6. Search update: April 2007 to August 2009}

\section{Search strategy for EMBASE (Ovid SP)}

\#1. exp sodium chloride/ or Ringer solution/

\#2. exp hypertonic solution/

\#3. (hypertonic adj3 $(\mathrm{NaCl}$ or saline or solution*)).mp.

\#4. $\# 1$ or $\# 2$ or \#3

$\# 5$. (glucose or fructose).mp.

\#6. \#4 not \#5

\#7. surgery/ or ((surg* adj3 procedur $\left.{ }^{*}\right)$ or surger* or operat*).ti,ab.

\#8. (RANDOM* ${ }^{*}$ or CROSS?OVER* or FACTORIAL* or PLACEBO* or VOLUNTEER* or ((SINGL* or DOUBL* or TREBL* or TRIPL*) adj3 (BLIND* or MASK*))).mp. not (animal not (human and animal)).sh.

\#9. \#6 and \#7 and \#8

\section{Search strategy for MEDLINE (Ovid SP)}

\#1. saline solution, hypertonic/or hypertonic solutions/

\#2. (hypertonic adj3 $(\mathrm{NaCl}$ or saline or solution*)).mp. or ringer.mp.

\#3. $\# 1$ or \#2

\#4. exp glucose solution, hypertonic/or colloid*.mp.

\#5. \#3 not \#4

\#6. $\quad$ exp surgical procedures, operative/or exp specialties, surgical/ or exp surgery/

\#7. ((surg* adj3 procedur*) or surger* or operat*).mp.

\#8. $\# 6$ or \#7

\#9. \#8 and \#5

\#10. ((randomized controlled trial or controlled clinical trial).pt. or randomized.ab. or placebo.ab. or drug therapy.fs. or randomly.ab. or trial.ab. or groups.ab.) not (animals not (humans and animals)).sh.

\#11. \#9 and \#10

\section{Search strategy for CINAHL (EBASCOhost)}

S1. (MM "Saline Solution, Hypertonic") or (MM "Hypertonic Solutions")

S2. (MH "Lactated Ringer's Solution")

S3. TX (hypertonic and $(\mathrm{NaCl}$ or saline or solution*)) or Ringer 
S4. (MH "Sodium Chloride")

S5. S1 or S2 or S3 or S4

S6. TX glucose or fructose

S7. S5 not $\mathrm{S6}$

S8. (MH "Surgery, Operative")

S9. TX surger* or operat*

S10. S8 or $S 9$

S11. S7 and S10

\section{Search strategy for CENTRAL, The Cochrane Library}

\#1 MeSH descriptor Saline Solution, Hypertonic explode all trees

\#2 $\mathrm{MeSH}$ descriptor Hypertonic Solutions explode all trees

\#3 (hypertonic $\mathrm{NaCl}$ ) or (hypertonic saline) or (hypertonic solution*)

\#4 Ringer* near solution*

\#5 Sodium Chloride

\#6 (\#1 OR \#2 OR \#3 OR \#4 OR \#5)

\#7 MeSH descriptor Glucose Solution, Hypertonic, this term only

\#8 (\#6 AND NOT \#7)

\#9 MeSH descriptor Surgical Procedures, Operative explode all trees

\#10 MeSH descriptor Specialties, Surgical explode all trees

\#11 MeSH descriptor Surgery explode all trees

\#12 (surg* near procedur*) or surger* or operat*

\#13 (\#9 OR \#10 OR \#11 OR \#12)

\#14 (\#8 AND \#13)

\section{H IS T O R Y}

Protocol first published: Issue 1, 2006

Review first published: Issue 1, 2010

\section{CONTRIBUTIONS OFAUTHORS}

Conceiving the review: T. Znajda (TZ), K. Burns (KB), V. McAlister (VM)

Co-ordinating the review: VM

Undertaking manual searches: TZ, K.B, VM

Screening search results: TZ, KB, VM, BC

Organizing retrieval of papers: TZ, VM

Screening retrieved papers against inclusion criteria: TZ, KB, VM

Appraising quality of papers: TZ, KB, VM

Abstracting data from papers: TZ, KB, VM, BC

Writing to authors of papers for additional information: VM

Obtaining and screening data on unpublished studies: TZ, KB, VM

Data management for the review: TZ, KB, VM

Entering data into Review Manager (RevMan 5.0): VM, KB

Hypertonic saline for peri-operative fluid management (Review)

Copyright (c) 2010 The Cochrane Collaboration. Published by John Wiley \& Sons, Ltd. 
RevMan statistical data: VM, KB

Other statistical analysis not using RevMan: KB

Double entry of data: (data entered by person one: VM ; data entered by person two: $\mathrm{KB}$ )

Interpretation of data: $\mathrm{TZ}, \mathrm{KB}, \mathrm{VM}$

Statistical analysis: TZ, KB, VM

Writing the review: VM

Securing funding for the review: Not applicable

Performing previous work that was the foundation of the present study: TZ, KB, VM, BC

Guarantor for the review (one author) VM

Persons responsible for reading and checking review before submission:TZ, KB, VM, BC

\section{DECLARATIONS OF INTEREST}

None. 